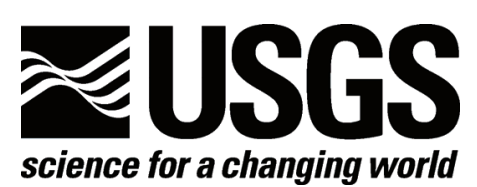

\title{
Herpetofaunal Inventories of the National Parks of South Florida and the Caribbean: Volume III. Big Cypress National Preserve
}

By Kenneth G. Rice', J. Hardin Waddle', Brian M. Jeffery', Amanda N. Rice ${ }^{2}$, H. Franklin Percival ${ }^{3}$

'U.S. Geological Survey, Florida Integrated Science Center

${ }^{2}$ University of Florida, Dept. of Wildlife Ecology and Conservation

${ }^{3}$ U.S. Geological Survey, Florida Cooperative Fish and Wildlife Research Unit

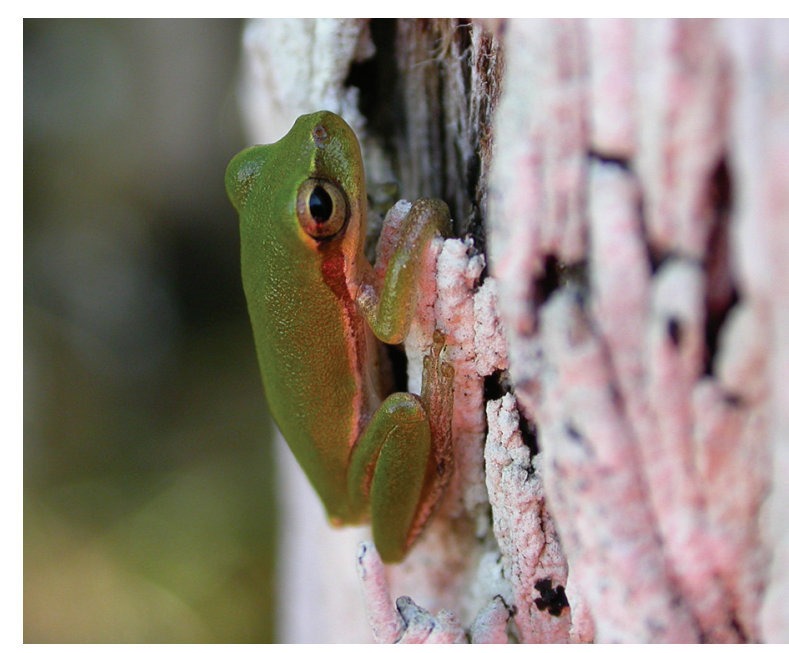

Open-File Report 2005-1300

U.S. Department of the Interior

U.S. Geological Survey 


\section{U.S. Department of the Interior Gale A. Norton, Secretary}

\section{U.S. Geological Survey \\ Patrick P. Leahy, Director}

\section{U.S. Geological Survey, Reston, Virginia}

Revised and reprinted: 2005

For product and ordering information:

World Wide Web: http://www.usgs.gov/pubprod

Telephone: 1-888-ASK-USGS

For more information on the USGS - the Federal source for science about the Earth, its natural and living resources, natural hazards, and the environment:

World Wide Web: http://www.usgs.gov

Telephone: 1-888-ASK-USGS

Any use of trade, firm, or product names is for descriptive purposes only and does not imply endorsement by the U.S. Government

Although this report is in the public domain, permission must be secured from the individual copyright owners to reproduce any copyrighted material contained within this report.

For more information about this report, contact:

Dr. Kenneth G. Rice, U.S. Geological Survey, Florida Integrated Science Center UF-FLREC, 3205 College Av., Ft. Lauderdale, FL 33314, USA

E-mail: ken_g_rice@usgs.gov Phone: 954-577-6305 Fax: 954-577-6347

J. Hardin Waddle, U.S. Geological Survey, Florida Cooperative Fish and Wildlife Research Unit

Box 110485, Building 810, University of Florida, Gainesville, FL 32611, USA

E-mail: hardin_waddle@usgs.gov Phone: 352-846-0638 Fax: 352-846-0841 


\section{Contents}

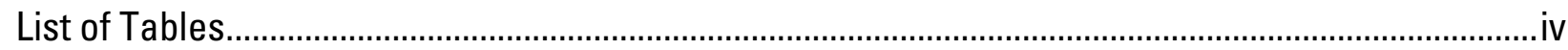

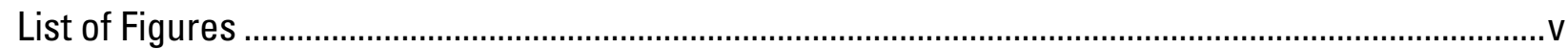

Abstract

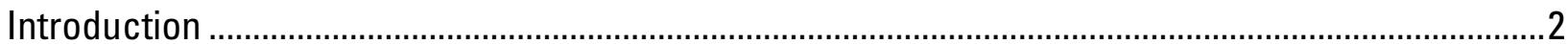

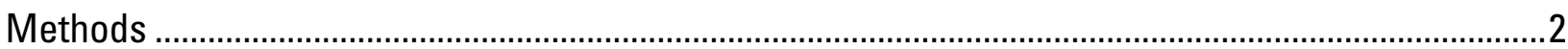

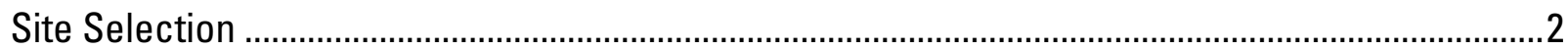

Visual Encounter Surveys .................................................................................................................

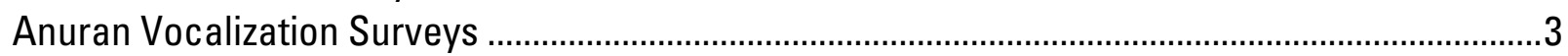

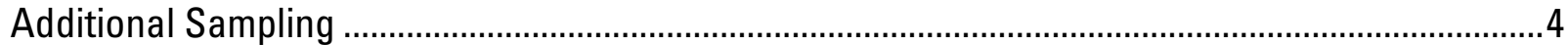

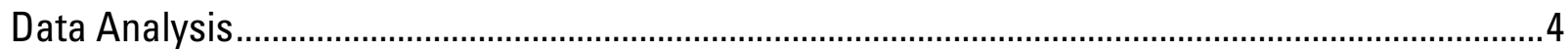

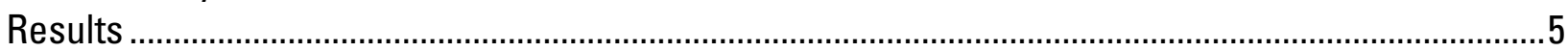

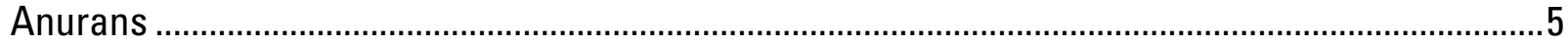

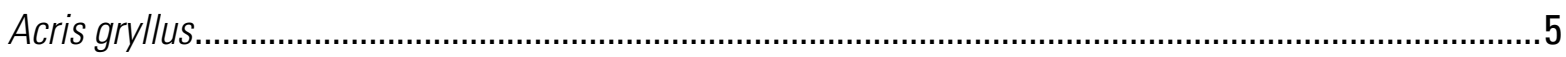

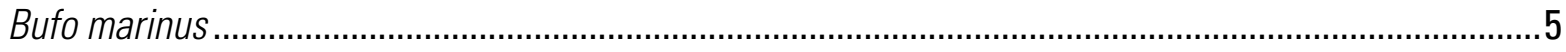

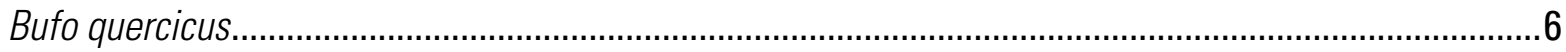

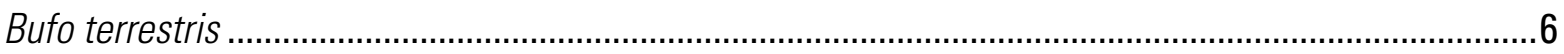

Eleutherodactylus planirostris ............................................................................................

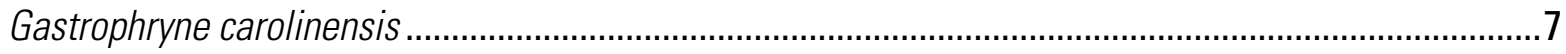

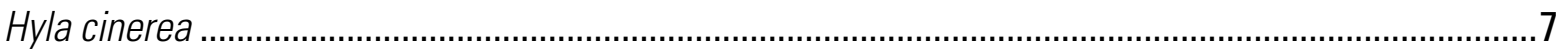

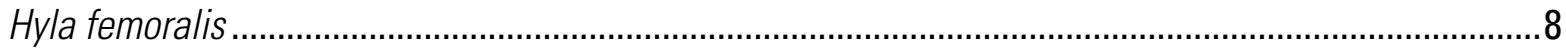

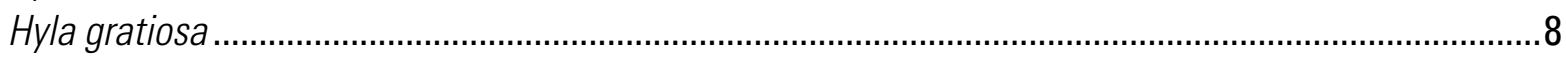

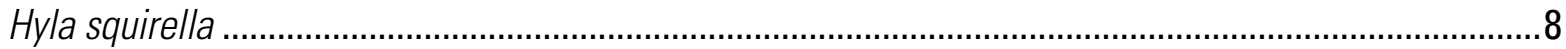

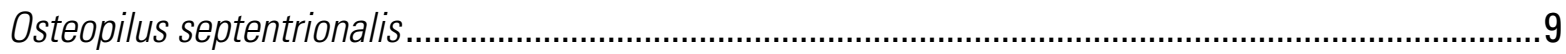

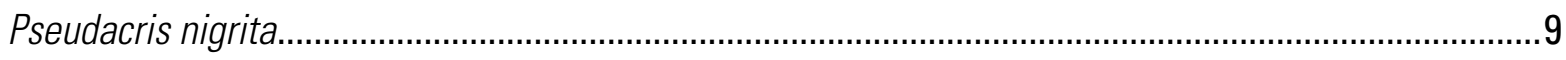

Pseudacris occularis............................................................................................................

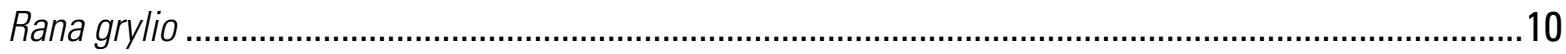

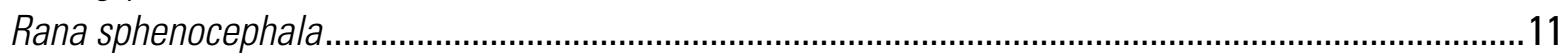

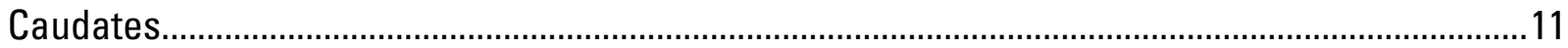

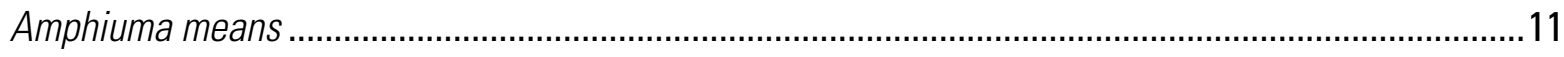

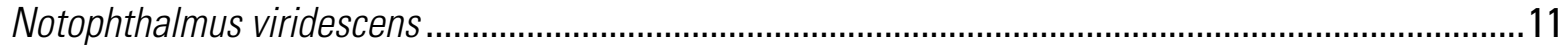

Pseudobranchus axanthus .....................................................................................................11

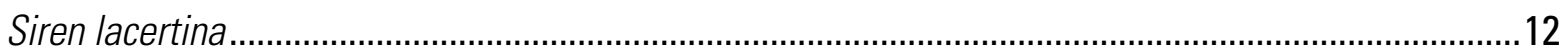

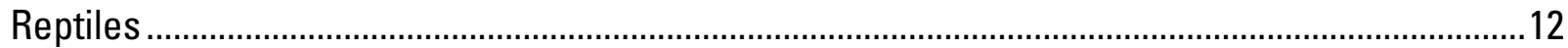

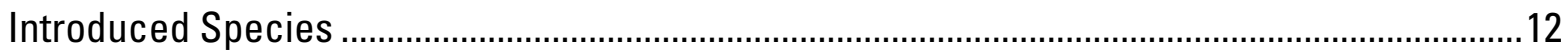

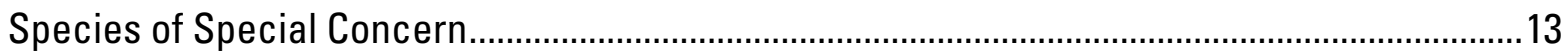

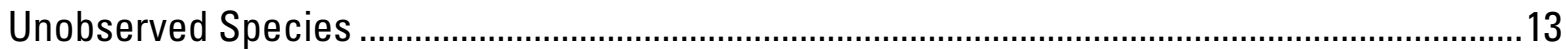

Summary and Conclusions ...................................................................................................... 13

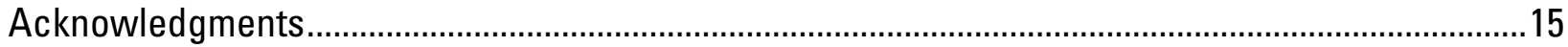

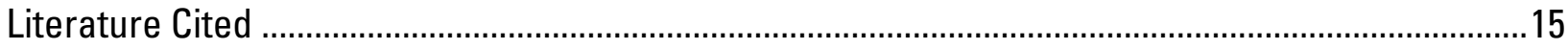

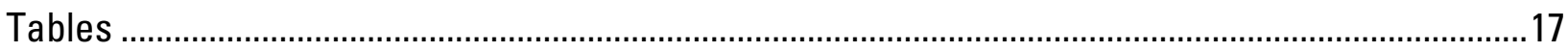

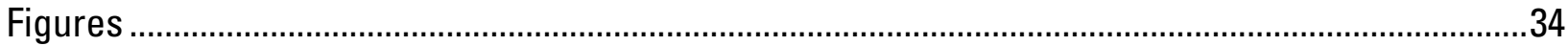




\section{List of Tables}

Table 1. Number of sampling sites and total number of site visits by habitat...................................18

Table 2. The 27 models chosen for testing with each species in program PRESENCE...................19

Table 3. Mean and range of snout-vent length of amphibians measured during visual encounter

survey.

Table 4. Number of individuals captured and number of site visits during which at least one individual was heard vocalizing by habitat.

Table 5. Months in 2002-2003 during which individuals were detected by VES methods and vocalization.

Table 6. Average snout-vent length for individuals found using VES and opportunistic encounter surveys (stratified by habitat).

Table 7. Number of sites sampled, sites at which individuals were detected, and the minimum (naïve) and PAO estimate of the site occupancy rate by habitat. .

Table 8. Numbers of individual caudates captured by different survey methods......

Table 9. Reptiles believed to potentially occur in Big Cypress National Preserve, whether they are introduced, and whether they were encountered during this study.

Table 10. Reptile species found in Big Cypress National Preserve and the survey methods by which they were detected 


\section{List of Figures}

Figure 1. Map of southern Florida showing the location of Big Cypress National Preserve. ..........35

Figure 2. Vegetation classification of Big Cypress National Preserve.............................................36

Figure 3. Standard sampling site locations.. ……………………………………………….......

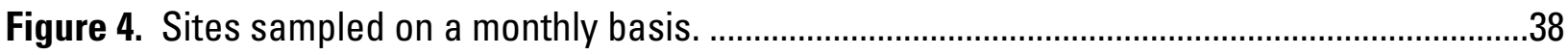

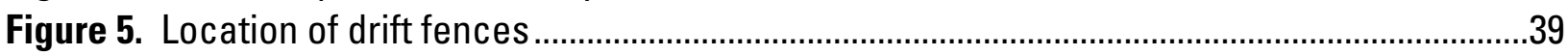

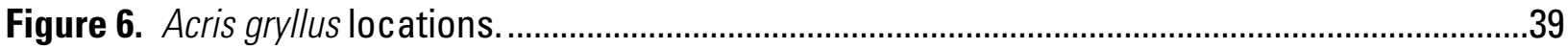

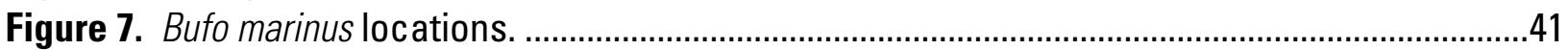

Figure 8. Bufo quercicus locations .............................................................................................42

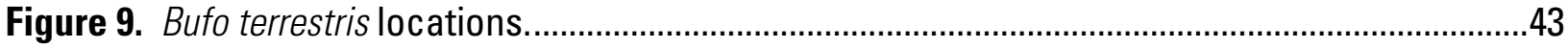

Figure 10. Eleutherodactylus planirostris locations ..........................................................................4

Figure 11. Gastrophryne carolinensis locations. ............................................................................45

Figure 12. Hyla cinerea locations. ...........................................................................................4

Figure 13. Hyla gratiosa locations. ...........................................................................................4

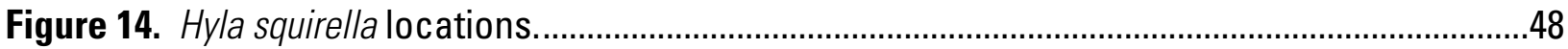

Figure 15. Osteopilus septentrionalis...........................................................................................49

Figure 16. Pseudacris nigrita locations .........................................................................................4

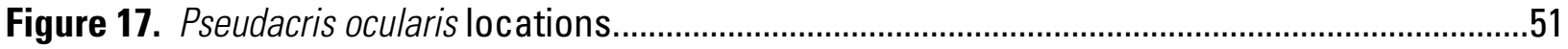

Figure 18. Rana grylio locations................................................................................................52

Figure 19. Rana sphenocephala locations.....................................................................................5

Figure 20. Amphiuma means locations.........................................................................................5

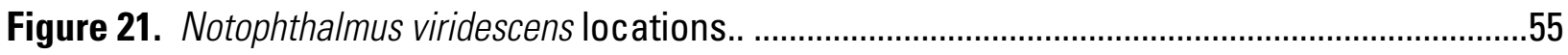

Figure 22. Pseudobranchus axanthus belli locations. ....................................................................56

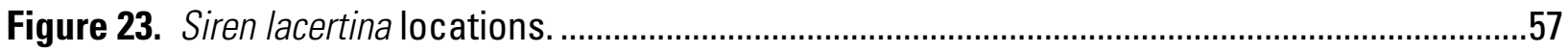

Figure 24. Alligator mississippiensis locations. ..............................................................................58

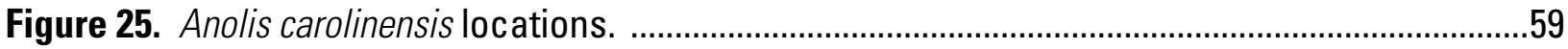

Figure 26. Anolis sagrei locations...........................................................................................59

Figure 27. Eumeces inexpectatus locations....................................................................................61

Figure 28. Hemidactylus garnotii locations...................................................................................62

Figure 29. Hemidactylus mabouia loc ations......................................................................................63

Figure 30. Iguana iguana loc ations. ...........................................................................................64

Figure 31. Ophisaurus compressus locations. ...........................................................................65

Figure 32. Scincella lateralis locations ......................................................................................66

Figure 33. Agkistrodon piscivorus locations..................................................................................67

Figure 34. Cemophora coccinea locations......................................................................................68

Figure 35. Coluber constrictor locations......................................................................................69

Figure 36. Crotalus adamanteus locations.............................................................................69

Figure 37. Diadophis punctatus locations..................................................................................

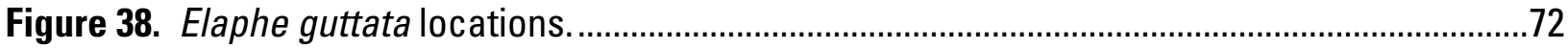

Figure 39. Elaphe obsoleta locations............................................................................................73

Figure 40. Lampropeltis getula locations.................................................................................

Figure 41. Lampropeltis triangulum locations. ...........................................................................75

Figure 42. Nerodia fasciata locations........................................................................................76 


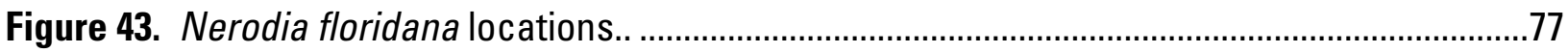

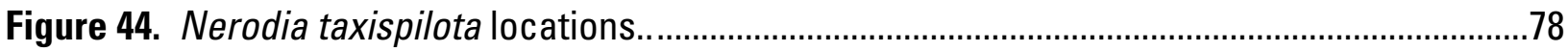

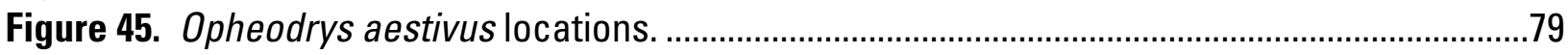

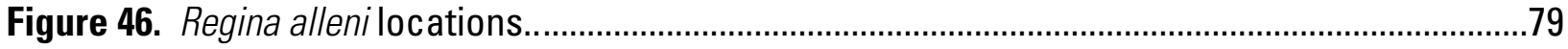

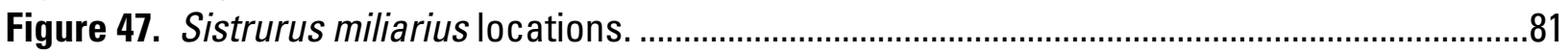

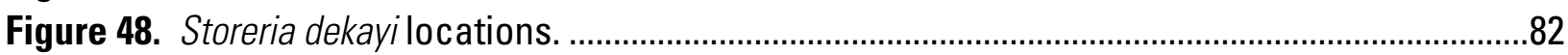

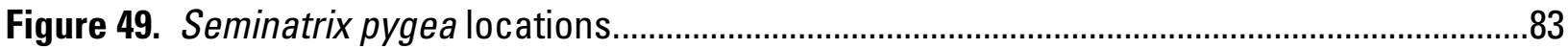

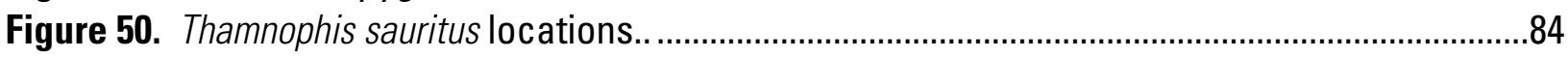

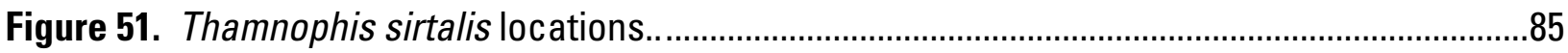

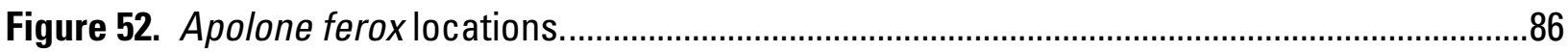

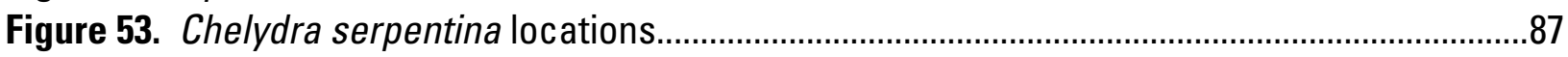

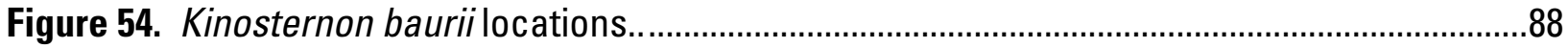

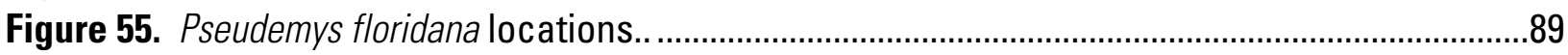

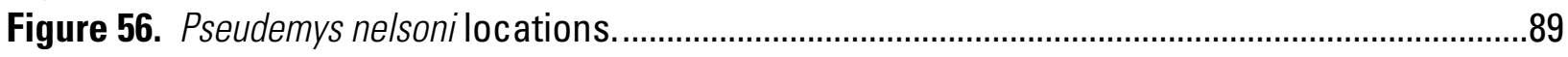

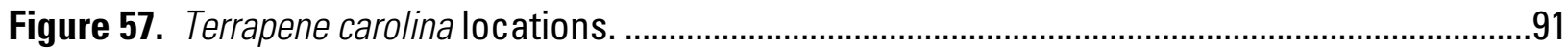




\section{Conversion Factors}

\begin{tabular}{lll}
\hline \multicolumn{1}{c}{ Multiply } & \multicolumn{1}{c}{ By } & \multicolumn{1}{c}{ To obtain } \\
\hline centimeter $(\mathrm{cm})$ & \multicolumn{1}{c}{ Length } & \\
millimeter $(\mathrm{mm})$ & 0.3937 & inch (in.) \\
meter $(\mathrm{m})$ & 0.03937 & inch (in.) \\
kilometer $(\mathrm{km})$ & 3.281 & foot (ft) \\
kilometer $(\mathrm{km})$ & 0.6214 & mile (mi) \\
meter $(\mathrm{m})$ & 0.5400 & mile, nautical (nmi) \\
& 1.094 & yard (yd) \\
\hline square meter $\left(\mathrm{m}^{2}\right)$ & Area & \\
hectare $($ ha) & 0.0002471 & acre \\
\hline
\end{tabular}

\section{Acronyms}

AIC Akaike's Information Criterion

BCNP Big Cypress National Preserve

$\mathrm{Cl} \quad$ Confidence interval

ENP Everglades National Park

GIS Geographic information system

ORV off-road vehicle

PAO proportion of area occupied

SD standard deviation

SE standard error

SVL snout-vent length

VES visual encounter surveys 


\section{Herpetofaunal Inventories of the National Parks of South Florida and the Caribbean: Volume III. Big Cypress National Preserve}

\section{Abstract}

Amphibian declines and extinctions have been documented around the world, often in protected natural areas. Concern for this trend has prompted the U.S. Geological Survey and the National Park Service to document all species of amphibians that occur within U.S. National Parks and to search for any signs that amphibians may be declining. This study, an inventory of amphibian species in Big Cypress National Preserve, was conducted from 2002 to 2003. The goals of the project were to create a georeferenced inventory of amphibian species, use new analytical techniques to estimate proportion of sites occupied by each species, look for any signs of amphibian decline (missing species, disease, die-offs, and so forth.), and to establish a protocol that could be used for future monitoring efforts.

Several sampling methods were used to accomplish these goals. Visual encounter surveys and anuran vocalization surveys were conducted in all habitats throughout the park to estimate the proportion of sites or proportion of area occupied (PAO) by each amphibian species in each habitat. Opportunistic collections, as well as limited drift fence data, were used to augment the visual encounter methods for highly aquatic or cryptic species. A total of 545 visits to 104 sites were conducted for standard sampling alone, and 2,358 individual amphibians and 374 reptiles were encountered. Data analysis was conducted in program PRESENCE to provide PAO estimates for each of the anuran species.

All of the amphibian species historically found in Big Cypress National Preserve were detected during this project. At least one individual of each of the four salamander species was captured during sampling. Each of the anuran species in the preserve was adequately sampled using standard herpetological sampling methods, and PAO estimates were produced for each species of anuran by habitat. This information serves as an indicator of habitat associations of the species and relative abundance of sites occupied, but it will also be useful as a comparative baseline for future monitoring efforts.

In addition to sampling for amphibians, all encounters with reptiles were documented. The sampling methods used for detecting amphibians are also appropriate for many reptile species. These reptile locations are included in this report, but the number of reptile observations was not sufficient to estimate PAO for reptile species. We encountered 35 of the 46 species of reptiles believed to be present in Big Cypress National Preserve during this study, and evidence exists of the presence of four other reptile species in the Preserve.

This study found no evidence of amphibian decline in Big Cypress National Preserve. Although no evidence of decline was observed, several threats to amphibians were identified. Introduced species, especially the Cuban treefrog (Osteopilus septentrionalis), are predators and competitors with several native frog species. The recreational use of off-road vehicles has the potential to affect some amphibian populations, and a study on those potential impacts is currently underway. Also, interference by humans with the natural hydrologic cycle of south Florida has the potential to alter the amphibian community.

Continued monitoring of the amphibian species in Big Cypress National Preserve is recommended. The methods used in this study were adequate to produce reliable estimates of the proportion of sites occupied by most anuran species, and are a cost-effective means of determining the status of their populations. 


\section{Introduction}

Declines in amphibian populations have been documented worldwide from many regions and ecosystems (Alford and Richards, 1999). No single cause for declines has been demonstrated, and it seems likely that several factors may interact to threaten populations (Carey and Bryant, 1995). A major factor in the loss of amphibian populations in the southeastern United States has been and continues to be the loss of habitat (Dodd and Cade, 1998). As part of its commitment to stewardship of the natural resources of the national parks, the National Park Service funded an inventory of the amphibians of Big Cypress National Preserve through the NPS Inventory and Monitoring Program. This report describes that inventory project, conducted during 2002 and 2003.

Big Cypress National Preserve (BCNP) protects 291,603 ha (hectares) of southwest Florida (Figure 1). BCNP primarily consists of shallow seasonal wetland habitats including marshes, sloughs, and cypress forests. The area is generally warm with average daily temperatures between 12 and $33^{\circ} \mathrm{C}$ and the rainfall pattern is seasonal with $70 \%$ of the $1400 \mathrm{~mm}$ average annual precipitation occurring between June and October. In addition, a portion of the park consists of upland habitat, primarily pine forest and subtropical hardwood hammock. These habitats combined make up a heterogeneous mosaic of open grasslands and forested wetlands and uplands.

This is the first systematic survey of the herpetofauna of Big Cypress and the only study of this detail to date in southwest Florida. Duellman and Schwartz (1958) produced the first complete species list of the herpetofauna of south Florida. Meshaka and others (2000) provide a list of species known from collections in adjacent Everglades National Park (ENP) as of 1999. Rice and others (2004) provide a detailed systematic survey of ENP using methods similar to this study. This work combined with a forthcoming report on the herpetofauna of Biscayne National Park will provide a complete survey of the amphibian species of the national parks of south Florida.

In addition to providing a sample of georeferenced locations of all amphibian species in BCNP, we also estimated the site occupancy rate of each species by habitat. The occupancy rate was estimated based on detection/non-detection data from repeated sampling at randomly chosen sites throughout the park using a model developed by MacKenzie and others (2002). This method can serve as an index of abundance, and it can be compared to future samples to determine trends in the status of amphibian populations. Encounters with reptiles were not common enough to provide sufficient data for site occupancy modeling, but location data on reptiles is included in this report.

\section{Methods}

We used several different methods to sample for amphibians at sites throughout BCNP in an attempt to identify populations of all amphibian species. In addition to standard sampling methods outlined below, opportunistic encounters with amphibians and reptiles were noted with details on the exact location of the capture and data on each individual animal.

\section{Site Selection}

Sampling sites were chosen randomly throughout BCNP using a geographic information system (GIS), and all of our sampling was stratified by major habitat type. We divided BCNP into five natural habitats: cypress, cypress prairie, prairie, hammock, and pineland (Figure 2). We created these habitat designations by condensing the vegetation classification scheme proposed by Madden and others (1999) into our five broader habitat categories. An additional category, disturbed area, was also created, but no sampling took place in disturbed habitat. 
We used ArcView 3.2 with the Animal Movement Analysis extension (Hooge and Eichenlaub, 1997 ) to select points at random within each major natural habitat type. We created more random points than could be sampled, so points were selected from the list of available points for sampling based on availability of access. Many parts of BCNP were inaccessible by the means available to us (for example, airboat, all-terrain vehicle, 4-wheel drive vehicle, and foot) given the time constraints imposed by the nature of this project. Access was also seasonably variable. Areas accessible by airboat during the wet season were not always accessible during the dry season. We sampled every habitat in BCNP for at least 12 consecutive months during the period between February 2002 and August 2003.

We visited 104 sites at least twice (Figure 3). The highest number of study sites (32) was in prairie habitat, and we visited between 12 and 25 sites in each of the other habitats (Table 1). The number of sampling occasions per site was variable. Some were sampled on a monthly basis during 2002-2003, and many were sampled no more than twice during the entire project. We used repeated sampling at a subset of the more accessible sites as an efficient way to estimate habitat-level occupancy rates. In addition we conducted less frequent sampling at more remote locations to obtain better data on species distribution within the park. Our analysis includes a total of 545 site visits to the 104 sites (Table 1). At least six sites in each habitat were sampled monthly between March 2002 and February 2003 when access was possible (Figure 4).

\section{Visual Encounter Surveys}

Our primary method of sampling was a standard visual encounter survey (VES; Heyer and others, 1994) conducted for 30 minutes at randomly chosen sites. All of our VES samples were initiated at least 30 minutes after sunset because preliminary surveys in ENP indicated that amphibians were more active and, therefore, more easily detected at night. Each VES was conducted by at least two experienced observers using 6-volt spotlights with halogen bulbs.

Our VES samples were collected within a $20-\mathrm{m}$ radius of the randomly chosen point, covering an area of $1,256 \mathrm{~m}^{2}$ (square meters). We thoroughly searched as much of each circular plot as possible in the time allotted, but judgment of the observers was used to determine which areas within the plot got the most emphasis. The goal was to find as many individual amphibians as possible. All possible amphibian locations could be searched, including trees and other vegetation as well as bare ground and leaf litter.

We attempted to capture each individual amphibian and reptile that was observed during a VES. The animals were identified to species and sex if possible, and the age/life stage (that is, juvenile, adult, larva, and so forth) was recorded. The snout-to-vent length (SVL) of each animal captured was measured in $\mathrm{mm}$, and the substrate on which each individual was first observed and the perch height, estimated to the nearest $10 \mathrm{~cm}$ (centimeters), was noted.

In addition to the biological data collected during a VES, we also collected some key environmental data in the field at the time of the survey. We measured the air temperature and relative humidity using a digital thermohygrometer. We recorded whether the plot was inundated with water and, if it was, the water temperature was measured and recorded. We also classified the weather into one of five categories: clear, partly cloudy, cloudy, rain, or fog. Wind speed was classified as none, light, moderate, or strong. The date and time of the sample and the observers present were also recorded. All data were recorded on personal digital assistants (PDAs) and later transferred to a Microsoft Access database (Waddle and others, 2003).

\section{Anuran Vocalization Surveys}

When a VES was conducted at each random point, we also noted all of the species of frogs and toads that were heard vocalizing. The vocalization survey was conducted over a 10 -minute period during the VES. All anurans that could be heard were included, even if it was possible or likely that they were 
calling from a location outside of the $20 \mathrm{~m}$ (meter) radius plot. Including all individuals heard eliminated the need to locate vocalizing individuals, and it facilitates comparison with similar surveys conducted elsewhere or in future studies in BCNP.

The abundance of vocalizing individuals was estimated as one of five categories: 1,2 to 5,6 to 10 , greater than 10, or large chorus. In addition, the frequency of calling by each species was categorized as occasional, frequent, or continuous. These categories were discussed with newer observers in the field so that a consensus could be reached on which category to place the abundance and frequency of calls.

\section{Additional Sampling}

We also used several other techniques in addition to the random sampling described above to attempt to fully document the amphibian fauna of BCNP. Most of this sampling was done to either augment the species list or as part of other research projects. Data from this additional sampling is only included in the list of species detected and their locations. Because sites were not randomly chosen and sampling efforts were not consistent, these data are not compatible with the proportion of sites occupied analysis technique used for the VES and vocalization surveys (see Data Analysis below).

Drift fences were used in a pilot study to examine the effects of off-road vehicle (ORV) use on the herpetofauna of the prairies of BCNP (Figure 5). These traps were primarily used to target aquatic salamanders, a group that was rarely observed during VES surveys. Traps were placed along side drift fences in open prairie habitat and sampled during the wet season of 2002. One species of amphibian, Pseudobranchus axanthus belli, was only detected by this method. Many species of reptiles were only detected opportunistically as we traveled on roads or through the preserve on our way to and from research sites. These locations were recorded with GPS coordinates for inclusion into a geo-referenced database.

\section{Data Analysis}

Detection probabilities for all amphibian and reptile species were assumed a priori to be less than one. Therefore, data were collected in a method compatible with the site occupancy model of MacKenzie and others (2002). Rather than assuming that a species is detected at every site in which it occurs, we estimate the true proportion of sites occupied. This estimate is always greater than or equal to the naive or minimum known occupancy (total number of sites at which the species was detected at least once). This method estimates sampling occasion specific detection probabilities for each species using maximum likelihood statistical techniques. By estimating detection probabilities, we were able to estimate the true site occupancy rate of each species by habitat, while taking into account the effects of environmental variables on the behavior of the animals. We do not need to assume that detection rates are constant across species, habitats, time, or environment. We do assume, however, that if a species is present, it has a detection probability greater than 0 . We also assume that sites are closed to changes in occupancy between subsequent samples, and we therefore only consider data from surveys that were conducted within six months of one another.

All data were compiled in Microsoft Access and then extracted as capture histories for analysis in program PRESENCE (MacKenzie and others, 2003). Our site-specific covariables, those that directly affect the estimate of occupancy ( $p s i$ ) were major habitat type and a broader habitat category (forested or grassland). Variables that affect detection probability $(p)$ were sampling occasion covariables: air temperature, relative humidity, presence of standing water, and season of the year. For each species, we considered twenty-seven models that were combinations of these variables that we determined to be biologically meaningful a priori (Table 2). The best model was chosen as the one with the lowest value for Akaike's information criterion (AIC), or the most parsimonious model (model with the best fit for the fewest parameters; Burnham and Anderson [1998]). Model selection in this manner allowed us to determine the factors that were most important in sampling for individual species, and the best estimate of 
the site occupancy of each species. We used the best model that included the six habitats as a factor to estimate the habitat-specific occupancy rates of each species using the logit of the coefficient for each habitat from the model (MacKenzie and others, 2002).

\section{Results}

During this project we encountered 2,358 amphibians and 374 reptiles during VES sampling. We also captured an additional 73 amphibians and 111 reptiles in drift fences and by opportunistic encounter. We detected a total of 18 amphibian species and 34 reptile species during this study. We measured the snout-to-vent length of a total of 1,904 amphibians (Table 3). This study did not target reptiles, but as some of the species are readily sampled using the same methods as those for amphibians we report the results below.

\section{Anurans}

\section{Acris gryllus}

The Florida cricket frog (Acris gryllus dorsalis) is widespread throughout BCNP. These frogs were detected in every habitat within the park using vocal survey (Table 4; Figure 6), and the species was heard on 168 of 545 sampling occasions. Cricket frogs were detected continuously by vocal survey between March and October in both 2002 and 2003. Although breeding may occur year round in this species, our results suggest that a vocal survey would be most effective during these months.

During VES, 35 cricket frogs were captured within BCNP. They were found in every habitat except for hammock. These occurrences were concentrated between June and August; however, they were also detected in March, October, and December (Table 5). Because of the small size of this species and the abbreviated period during which detection by visual methods was possible, vocalization may be the most effective method for surveying this species. Snout-vent lengths (SVL) were taken from 20 cricket frogs within BCNP. SVL measurements for this species ranged from 16 to $28 \mathrm{~mm}$ (millimeters) with a mean of $22.95 \mathrm{~mm}$ (+/- 0.63 SD) (Table 3). Mean SVL varied from 21.6 to $24.4 \mathrm{~mm}$ by habitat (Table 6).

The naïve or minimum site occupancy for the species was 76.92 percent overall, with values ranging from 66.67 to 88.24 percent among different habitats (Table 7). Using PAO modeling, we estimated that cricket frogs actually occurred in 96.8 percent $(\mathrm{SE}=0.0211)$ of all sites within BCNP. The best model (model weight 0.6802 ) for site occupancy estimation included the two-habitat category (forested versus non-forested), the presence/absence of water, and season as covariates. A model that assumed constant occupancy across habitat types but with the same sampling covariates had a weight of 0.3198. This suggests that detection of cricket frogs is probably seasonal and somewhat dependent on the presence of water, while occupancy may or may not depend on habitat type. Cricket frogs are primarily aquatic, so it is very reasonable that the presence of standing water would influence their detection. Using the best model that included all five habitat types, the estimate of site occupancy for each habitat was computed, and results ranged from 86 to 100 percent among the habitats (Table 7).

\section{Bufo marinus}

The Marine or Cane toad (Bufo marinus) was introduced into south Florida during the 1960s as both a control for agricultural pests and as a pet (Duellman and Schwartz, 1958). We were the first to detect this species in ENP, and based on these results, it appears to be increasing its range in southern Florida (Rice and others, 2004). Vocalizations were heard at several sites during this inventory, but no individuals were captured within plots during VES surveys. Marine toads were heard calling in prairie and pineland habitats within BCNP (Table 4; Figure 7) on 5 of 545 visits. Marine toad vocalizations were heard 
in the winter months of December and January and again heard during the summer from June through August (Table 5), suggesting that this species may be active year-round in south Florida. The fact that no marine toads were found during VES surveys and relatively few were detected by vocal surveys may indicate that this species has only recently begun to invade BCNP.

\section{Bufo quercicus}

The oak toad (Bufo quercicus), a small diurnal bufonid, was detected in every habitat in BCNP; however, it was only heard during 17 of 545 visits. Only two individuals were found during VES, one in prairie and one in pineland habitat (Table 4; Figure 8). B. quercicus was detected by vocalization during the months of January, March, May and June, and was detected by VES in July and October (Table 5). The low number of oak toads detected by this survey is probably not reflective of their true distribution and abundance. Bufo quercicus, unlike other toads in the park, is chiefly active during the day. Therefore, the design of this study (sampling at night) was less appropriate for this particular species. Snout-vent length was measured from the two individual oak toads collected during this study (Table 3; Table 6).

The naïve or minimum site occupancy for the species was 14.42 percent overall, with values ranging from 5.56 to 20.00 percent among different habitats (Table 7). We estimate, based on PAO modeling, that $B$. quercicus occupied 65.22 percent $(\mathrm{SE}=0.2776)$ of all sites within BCNP. The best model (model weight $=0.5087$ for site occupancy estimation included the two-category habitat designation, the presence of water, and the four seasons as covariates. A similar model (but with occupancy constant across habitat types) had a high weight (model weight $=0.4623$ ) as well. These results suggest that although habitat may or may not be useful for predicting occupancy, season and the presence of standing water are probably important factors affecting the detection probability of oak toads. Using the best model, which included all five habitat types, we computed the estimate of site occupancy for each habitat, results ranged from 23 to 90 percent among the habitats (Table 7).

\section{Bufo terrestris}

Another toad within BCNP, the southern toad (Bufo terrestris), was detectable using our methods. Southern toads were heard calling in all habitats within BCNP on 26 of 545 sampling occasions (Table 4). Vocalizations were heard from March through September and again in December (Table 5). This corresponds with the known breeding pattern for this species, which may occur from March to October depending on rainfall and weather conditions (Conant and Collins, 1991).

Southern toads were found visually in cypress, hammock, and pineland habitats (Table 4; Figure 9). Twenty specimens were found during VES, and these specimens were found in March, April, and May (Table 5). Mean SVL of Bufo terrestris within BCNP was $65.1 \mathrm{~mm}$ (+/- 5.5 SD) with a range of 20 to 97 $\mathrm{mm}$ (Table 3). Due to the low number of individuals captured during this study, we were unable to determine if significant differences existed in the mean SVL of southern toads for different habitats (Table $6)$.

The naïve or minimum site occupancy for the species was 21.15 percent overall, with values ranging from 11.76 to 32.00 percent among different habitats (Table 7), but we estimated the occupancy rate of $B$. terrestris to be 90.16 percent $(\mathrm{SE}=0.1271$ ) overall within $\mathrm{BCNP}$. The best model for site occupancy estimation (model weight $=0.976$ ) included the two-category habitat classification (forested/non-forested) and season. No other model had significant weight. Using the best model including all five habitats, we estimated the site occupancy for each habitat. Results ranged from 45 to 100 percent among the habitats (Table 7). 


\section{Eleutherodactylus planirostris}

Possibly the most widespread of the three established exotic anurans in south Florida, the Greenhouse frog (Eleutherodactylus planirostris planirostris) was detected throughout BCNP (Figure 10). Greenhouse frogs were heard vocalizing on 132 of 545 visits in BCNP (Table 4). Vocalizations were heard from March through November (Table 5). During VES, 39 greenhouse frogs were found in BCNP in all habitat types (Table 4). These frogs were found during every month except January (Table 5), which suggests that they are active year-round in south Florida. Based on the data collected during this study, it seems that either visual or vocal surveys are viable methods for monitoring greenhouse frogs. Snout vent lengths of greenhouse frogs ranged from 14 to $25 \mathrm{~mm}$ with a mean of $19.5 \mathrm{~mm}$ (+/- 0.86SD) (Table 3). We were unable to determine if significant differences existed in mean size of greenhouse frogs by habitat (Table 6).

The naïve or minimum site occupancy for the species was 50.0 percent overall, with values ranging from 21.88 to 83.33 percent among different habitats (Table 7). We estimate that E. p. planirostris actually occupies 83.02 percent $(\mathrm{SE}=0.0684)$ of all sites within $\mathrm{BCNP}$. The best model (model weight $=$ 0.6069 ) for site occupancy estimation included the two-category habitat parameter the presence of standing water, and season as covariates. A model with constant site occupancy across habitats but with the same sampling covariables had a weight of 0.3784. These models indicate that general habitat type may affect the site occupancy of greenhouse frogs, and that the presence of water and time of year affect the detection of this species. We computed the estimate of site occupancy for each habitat using the best model that included all habitat categories. Results ranged from 66 to 100 percent among habitats (Table 7).

\section{Gastrophryne carolinensis}

Eastern narrowmouth toads (Gastrophryne carolinensis) were heard on 16 of 545 vocal surveys within BCNP (Figure 11; Table 4). Vocalizations were heard during March, June through August, and November (Table 5). Narrowmouth toads are explosive breeders, with short breeding periods concurrent with warm seasonal rains (Conant and Collins 1991). These frogs were heard in every habitat within the park except prairie. Visual surveys located eight individual narrowmouth toads in cypress, hammock, and

pineland habitats (Table 7). Gastrophryne carolinensis were found by VES from March through May, suggesting that this may be the time period during which visual survey is most effective. Snout vent lengths of narrowmouth toads ranged from 15 to $26 \mathrm{~mm}$ with a mean value of $22.2 \mathrm{~mm}(+/-2.08 \mathrm{SD})$ (Table 3). No inferences could be made about differences in SVL by habitat for this species (Table 6).

The naïve or minimum site occupancy for the species was 20.19 percent overall, with values ranging from 6.25 to 36.00 percent among different habitats (Table 7). We estimate that G. carolinensis actually occupied 62.81 percent $(\mathrm{SE}=0.2425$ ) of sites overall within BCNP. The best model (model weight $=0.8950$ ) for site occupancy estimation included the forested versus nonforested habitat category as a site covariate and season as a sampling covariate. Little weight was given to the model with constant occupancy across habitat type and season. These results indicate that season is important in detection of narrowmouth toads and that major habitat structure is probably important in determining occupancy. The best model that included all five habitats provided an estimate of site occupancy by habitat that ranged from 36 to 100 percent (Table 7).

\section{Hyla cinerea}

The green treefrog (Hyla cinerea) was a commonly observed amphibian species during our sampling in BCNP. This species was detected in every habitat in the park using either VES or vocalization methods (Table 4; Figure 12). Hyla cinerea appears to be a habitat generalist in BCNP. We captured 797 
individual $H$. cinerea during VES surveys, and we heard at least one $H$. cinerea vocalizing during 119 of our 545 samples.

We detected $H$. cinerea during every month of our sampling (Table 5). H. cinerea was captured during VES surveys in every month, and detected through vocalizations from March through October and again in December. This suggests that $H$. cinerea remains active throughout the year and may always be detectable using VES techniques. Morphometric data were collected from $684 \mathrm{H}$. cinerea captured during VES. The overall mean SVL of green treefrogs in BCNP was $31.07 \mathrm{~mm}$ (+/- 0.31 SD) and a range from 14 to $58 \mathrm{~mm}$ (Table 3 ).

The naïve or minimum site occupancy for the species was 87.50 percent overall, with values ranging from 65.63 to 100.00 percent among different habitats (Table 7). We estimate that $H$. cinerea actually occupies 98.68 percent $(\mathrm{SE}=0.0313)$ of all sites within $\mathrm{BCNP}$. The best model $($ model weight $=$ 0.4487) for site occupancy estimation included the forested versus non-forested habitat designation and temperature, humidity, and the presence/absence of water as covariates. A model including all of the same covariables except humidity had a high weight as well (0.3324). Habitat structure is probably an important factor for site occupancy of green treefrogs, and detection appears to be dependent on temperature, the presence of water, and sometimes humidity. Taking the best model using the five habitat categories, we computed an estimate of site occupancy for each habitat. Results ranged from 82 to 100 percent among the habitats (Table 7).

\section{Hyla femoralis}

The pine woods treefrog, Hyla femoralis, was not detected in BCNP during this study. This species has been collected in Collier County, Florida and has recently been detected in nearby Picayune Strand State Forest (David Ceilley, Conservancy of Southwest Florida, oral comm., 2005). Big Cypress staff have reported finding this species in the past in the Raccoon Pt. area, but we were unable to detect the species. This species may be on the edge of its range in BCNP. It has never been found in ENP (Meshaka and others, 2000). More research on the habitat requirements, especially the breeding habitat of this species might help explain its apparent low numbers in BCNP.

\section{Hyla gratiosa}

The barking treefrog (Hyla gratiosa) appears to be at the southern edge of its range in BCNP. This species was only detected during standard sampling using the vocalization technique, and was not observed within VES plots (Figure 13). We heard at least one H. gratiosa vocalizing during 3 of our 545 sampling occasions, in hammock and pineland habitats (Table 4), and all vocalizations heard were during the month of August (Table 5). The individuals that were observed opportunistically were found at breeding sites. It appears that this species is breeding within the preserve, but probably occurs in very low density.

\section{Hyla squirella}

The squirrel treefrog (Hyla squirella) was the most commonly observed amphibian in BCNP. $H$. squirella was detected by VES and by vocalization in every habitat (Figure 14). Hyla squirella is a habitat generalist, and appears to be ubiquitous in BCNP. A total of 1,144 H. squirella were found using VES, and the species was heard during 60 of 545 sampling occasions (Table 4).

$H$. squirella was detected by VES during all months of the survey. Detection of $H$. squirella by vocalization occurred from March through August (Table 5). The absence of this species during several months of vocal surveys suggests that VES may be a more effective survey method for $H$. squirella. SVL Measurements were taken from 1,009 individual $H$. squirella captured by VES across the five habitats 
(Table 6). The mean SVL for squirrel treefrogs in BCNP was $20.93 \mathrm{~mm}(+/-0.14$ SD), which is slightly lower than the published size range for this species (Table 3).

The naïve or minimum site occupancy for $H$. squirella was 66.35 percent overall, with values ranging from 37.50 to 92.00 percent among different habitats (Table 7). Using site occupancy modeling, we estimated that $H$. squirella occupied 79.98 percent $(\mathrm{SE}=0.0522)$ of all sites within $\mathrm{BCNP}$. The best model for site occupancy estimation (model weight $=0.4455$ ) included the two-category habitat designation as a site covariate and air temperature and presence/absence of water as sampling covariates. A model including the two habitats and season and presence of water produced a similar AIC value with a model weight of 0.3654 . These models suggest that habitat structure is probably an important influence on occupancy, and water is important for detection. Using the best model, which included all five habitats, the estimated site occupancy for each habitat ranged from 51 to 100 percent among the habitats (Table 7).

\section{Osteopilus septentrionalis}

The Cuban treefrog (Osteopilus septentrionalis) is an exotic hylid species primarily found in disturbed areas of BCNP (Figure 15). We detected $O$. septentrionalis during vocal surveys in every habitat type except cypress (Table 4). Twelve individuals of $O$. septentrionalis were captured during VES, and at least one vocalization was heard during 5 of the 545 sampling occasions. The overall mean SVL of Cuban treefrogs captured during this study was $61.2 \mathrm{~mm}$ (+/- 5.70 SD) (Table 3).

O. septentrionalis was detected by VES in all months of sampling except March, April, August, and September. This indicates that $O$. septentrionalis is active throughout the year and may always be detectable using visual techniques. $O$. septentrionalis was detected by vocal survey during April, and again from July through September (Table 5).

The naïve or minimum site occupancy for the species was 5.77 percent overall, with values ranging from 0.00 to 16.67 percent among different habitats (Table 7). We estimate that O. septentrionalis actually occupied 13.05 percent $(\mathrm{SE}=0.0513)$ of all sites within BCNP, which is much lower than the 34.66 percent overall PAO estimate for Cuban treefrogs from ENP. The best model for site occupancy estimation (model weight $=0.5357$ ) assumed constant occupancy across habitats and included the presence of water as a sampling covariate. A model with constant occupancy and detection had a low delta AIC (model weight $=0.1770$ ) and may also be reasonable. These models indicate that the habitat and detection covariables do not adequately explain the distribution of Cuban treefrogs. This species has only recently invaded BCNP and is still primarily found near roads, buildings, and other disturbed areas. The best model that included all five habitats produced an estimate of site occupancy for each habitat that ranged from 0 to 29.7 percent among the habitats (Table 7).

\section{Pseudacris nigrita}

The southern chorus frog (Pseudacris nigrita) is a relatively rare hylid species within the preserve. $P$. nigrita was found in cypress and cypress prairie habitat during VES surveys. Vocal surveys detected southern chorus frogs in all habitat types in BCNP (Figure 16). Only 5 individuals of this species were captured, and vocalizations were only heard during 25 of our 545 sampling occasions (Table 4). The mean snout-vent length of southern chorus frogs was $25.3 \mathrm{~mm}$ (+/- 2.67 SD) (Table 3). There was insufficient data to examine differences in SVL by habitat (Table 6). P. nigrita was detected by vocal surveys from March through June and again in December, and VES detection of $P$. nigrita was sporadic (Table 5).

The naïve or minimum site occupancy for the species was 17.31 percent overall, with values ranging from 9.38 to 25.00 percent among different habitats (Table 7). The overall estimate of true site occupancy is 55.08 percent $(\mathrm{SE}=0.1281)$. The best model (model weight $=0.5151)$ for estimation assumed constant occupancy across habitats and used air temperature, relative humidity, and the 
presence/absence of water as sampling occasion covariates. The next best model (model weight $=0.1865)$ was essentially the same but it excluded relative humidity. These results indicate that either habitat structure is not important to the occupancy of chorus frogs in BCNP, or encounter rates were too low to identify real habitat associations. Air temperature and the presence of water are probably important for detection, although since water levels increase during the summer in BCNP, the two are probably correlated. The best model, which included all five habitats, produced habitat-specific occupancy rates between 40 and 69 percent (Table 7).

\section{Pseudacris occularis}

The little grass frog (Pseudacris occularis) was detected in every habitat in BCNP. Ninety-seven individuals of $P$. occularis were found during VES (Table 6). This species appears to be much more abundant in BCNP than in ENP (Rice and others, 2004). Vocalizations for P. occularis were heard in all habitats except hammock (Figure 17), and the species was heard on 54 out of 545 sampling occasions (Table 4). P. occularis was encountered using VES during every month of the survey. Vocalization surveys detected $P$. occularis from May thorough September and again in December (Table 5). The mean SVL for P. occularis was 13.60 (+/- 0.22 SD) (Table 3). Little grass frogs were observed more often in BCNP than they were in ENP (Rice and others, 2004). It is not clear whether ENP represents the extreme edge of their range, or if the heterogeneous nature of the habitats in BCNP creates a more suitable environment for the species.

The naïve or minimum site occupancy for the species was 27.88 percent overall, with values ranging from 12.50 to 52.00 percent among different habitats (Table 7). We estimate that little grass frogs actually occur at 48.02 percent $(\mathrm{SE}=0.0752)$ of all sites within BCNP. The best PAO model (model weight $=0.5886$ ) assumed constant occupancy across habitat types and included season and the presence/absence of water as sampling covariables. The second and third best models (model weights = 0.1400 and 0.1079 , respectively) were ones with the two-category habitat and the same sampling covariables and one with constant occupancy and only season as a sampling covariable, respectively. It appears that habitat is not very important in determining whether little grass frogs will be present in BCNP, but time of year probably is important for detection. The best model which included all five BCNP habitats produced habitat specific occupancy estimates of 33.05 to 74.24 percent (Table 7)

\section{Rana grylio}

The pig frog (Rana grylio) is common throughout the wetter areas of south Florida. This species was detected in every habitat of BCNP using both VES (Table 6) and vocalization techniques (Table 4; Figure 18). A total of 52 individuals of $R$. grylio were captured during VES, and the species was heard vocalizing during 195 of 545 sampling occasions. The overall mean SVL of pig frogs within BCNP was $64.35 \mathrm{~mm}$ (+/- 5.89 SD; Table 3). During the study, R. grylio was captured and detected by vocalization during every month of VES (Table 5). This suggests that this species may remain active throughout the year, and that both survey techniques are efficient at detecting $R$. grylio in BCNP. Pig frogs are known to be relatively aquatic, and are seldom found far from water. In BCNP, however, the heterogeneous nature of the habitat means that most sites are close enough to water to hear pig frogs vocalize.

The naïve or minimum site occupancy for the species was 80.77 percent overall, with values ranging from 65.63 to 91.67 percent among different habitats (Table 7). We estimate that $R$. grylio actually occupied 99.96 percent $(\mathrm{SE}=0.0267$ ) of all sites within BCNP. The best model for site occupancy estimation included the two-category habitat designation and season as a sampling covariate; no other models had any weight. No models with all five habitats were able to converge, so we are unable to produce an estimate of occupancy among habitats for pig frogs (Table 7) 


\section{Rana sphenocephala}

The southern leopard frog (Rana sphenocephala) was also found throughout BCNP. This species was encountered using VES (Table 6) and vocalization surveys in every habitat (Table 4; Figure 19). The mean SVL of captured individuals ranged from 28 to $100 \mathrm{~mm}$, with a mean of $54.86 \mathrm{~mm}$ (+/- $2.32 \mathrm{SD})$ (Table 3). $R$. sphenocephala was encountered during every month of our sampling during VES surveys, and they were detected during every month except March and May using vocalization surveys (Table 5). One hundred and forty two $R$. sphenocephala were found during VES surveys, and at least one individual was heard vocalizing during 87 of our 545 sampling occasions.

The naïve or minimum site occupancy for the species was 75.96 percent overall, with values ranging from 64.00 to 84.38 percent among different habitats (Table 7). Estimates indicate that $R$. sphenocephala actually occupies 98.79 percent $(\mathrm{SE}=0.240)$ of all sites within BCNP. The best model for site occupancy estimation (model weight $=0.5965$ ) assumed constant occupancy across habitats and included temperature and the presence/absence of water as detection covariates. A model with the same sampling covariates, but including the two-category habitat designation also had some support (model weight $=0.1284)$, as did a model including humidity (model weight $=0.1245)$. Using the best model that included all habitat types, the estimate of site occupancy by habitat ranged from 93 to 100 percent (Table 7).

\section{Caudates}

\section{Amphiuma means}

The two-toed amphiuma (Amphiuma means) was one of the most numerous salamanders found during this study. A total of 8 individuals were captured using various survey techniques (Table 8). Four individuals were observed during VES surveys and four were observed opportunistically. Locations of these captures are shown in Figure 20. Interestingly, no amphiuma were captured during drift fence trapping in prairie habitat. This species is probably more common than the numbers captured in this study suggest. The sampling performed for this study was not ideal for capturing or detecting Amphiuma. The majority of the Amphiuma captured in ENP were by catch in drift fences intended to capture fish (Rice and others, 2004). No PAO analysis was performed for this species due to the low number of captures.

\section{Notophthalmus viridescens}

The peninsula newt (Notophthalmus viridescens piaropicola) is the only member of the family salamandridae found in south Florida, and it was also present within BCNP. A total of 4 individuals were found in the preserve, with the majority being observed opportunistically (Table 8; Figure 21). Only one individual was detected during VES. This species is probably best sampled with minnow traps in flooded habitats. Fish sampling performed by a crew working for the National Audubon Society and the U.S. Geological Survey detected many more newts than this study (Greg Ellis, National Audubon Society, oral comm., 2004). The sampling most appropriate for newts is not compatible with sampling for other amphibians. No PAO analysis was performed for this species, as there were not enough captures for estimation of occupancy rates.

\section{Pseudobranchus axanthus}

Only one individual of the Everglades dwarf siren (Pseudobranchus axanthus belli), a subspecies endemic to south Florida, was found during this survey. This species was listed as occurring in ENP (Meshaka and others, 2000), but was not detected during a survey similar to this one in 2001-2002 (Rice and others, 2004). The single individual that was captured came from a drift fence in a short-hydroperiod 
prairie habitat (Table 8; Figure 22). Unfortunately the specimen was found dead in the trap, but the individual was collected. A frozen tissue sample was given to Paul Moler of the Florida Fish and Wildlife Conservation Commission, who is overseeing a study of the systematics of Pseudobranchus.

\section{Siren lacertina}

Another member of the family sirenidae, the greater siren (Siren lacertina), was detected within the park using our methods. A total of eight greater sirens were found during this study (Table 8). Seven of these individuals were captured in drift fence arrays in short-hydroperiod prairie habitat (Figure 5). One individual was also detected opportunistically during the study (Figure 23). This species is certainly underrepresented in this study. Subsequent studies in Big Cypress have detected high local abundances of greater siren. Trapping appears to be the only reliable method for detection of this species, and trapping at every site at which we surveyed was outside the scope of this project. No PAO analysis was conducted on this species as capture numbers were so low, but this species is the focus of a new project examining the expected benefits of Everglades restoration activities to the amphibian fauna of south Florida.

\section{Reptiles}

The primary focus of this study was to sample amphibian species within Big Cypress, but many of the methods used were also appropriate for sampling reptiles. We have therefore collected and summarized the data on reptile species encountered during this study. Meshaka and others, (2000) listed 57 species of reptiles present in ENP. Based on this work and the list provided by Duellman and Schwartz (1958), we believe that there are potentially 58 species of reptiles in natural areas of south Florida (this excludes introduced species known only from urban areas in Miami-Dade and Broward Counties).

Excluding marine species and species with no known populations in southwest Florida, we believe that there are potentially 46 species of reptiles in BCNP (Table 9). During this study, we encountered 35 of those species (Table 10). Locations of occurrences by species are shown alphabetically within classes: Crocodilians (Figure 24), Lizards (Figures 25-32), Snakes (Figures 33-51), and Turtles (Figures 52-58).

\section{Introduced Species}

Four reptile species found during this study are exotic to south Florida. The brown anole, Anolis sagrei, was the most abundant exotic reptile found in the park, with 252 individuals being found during VES alone. Brown anoles were primarily found near disturbed areas within the park (Figure 26). Two other introduced reptile species, the tropical house gecko (Hemidactlyus mabouia), and the Indo-Pacific gecko (Hemidactylus garnotii) were only found on or near buildings and disturbed areas. Only two house geckos were found during VES surveys, and the Indo-Pacific gecko was only found opportunistically. The fourth exotic reptile encountered during this study was the green iguana. One individual of this species was collected from U.S. 41 in the preserve.

Three of the "potential" reptiles that were not observed during this study are introduced. One, the Burmese python, Python molorus, has been seen by BCNP staff as recently as March 2004. This species probably occurs in BCNP and may even be breeding in the preserve. Evidence from ENP suggests that this species is breeding there (Skip Snow, National Park Service, oral communication, 2005). The two other potential introduced reptiles in BCNP are the Brahminy blind snake, Ramphotyphlops braminus, and the Mediterranean gecko, Hemidactylus tursicus. The blind snake is most often introduced through landscaping material (Conant and Collins, 1991). We did not find blind snakes during this study, but they have been previously documented from Monroe Station in BCNP along U.S. Hwy. 41 (Deb Jansen, National Park Service, oral communication, 2005). The Mediterranean gecko is likely to occur on 
buildings in BCNP, but was not detected in any natural areas. This species has spread throughout southern Florida, but is primarily restricted to edifices.

\section{Species of Special Concern}

No reptiles of conservation concern were found during this study. There are four known or thought to occur in BCNP, but they were not detected by any of our methods. The gopher tortoise, Gopherus polyphemus, is listed by the state of Florida as a "species of special concern." Most of the land in Big Cypress is too poorly drained for tortoises, but some areas in the addition lands may be suitable.

Dalrymple (1995) did report discovering some gopher tortoises. The eastern indigo snake, Drymarchon corais, is federally listed as threatened. We did not find any indigo snakes during any of our work, but other researchers have located them as recently as December 2004 in the addition lands area. No information on the status of either of these species in BCNP is available at this time.

Two other reptiles of conservation concern are the American alligator, Alligator mississippiensis, and the American crocodile, Crocodylus acutus. The alligator is listed as a "species of special concern" by the state of Florida, and as "threatened due to similarity of appearance" by the U.S. Fish and Wildlife Service. Alligators are widespread throughout the park and 7 individuals were found during our VES (Figure 24). The American crocodile is listed as "endangered" by both the state of Florida and the U.S. Fish and Wildlife Service. One individual of this species was observed in the canal just north of U.S. 41 on the western border of the preserve after this project was concluded. The crocodile is probably an occasional resident of BCNP, but the status of this species in the preserve is unknown.

\section{Unobserved Species}

Only three other snake and two other turtle species were not observed during this study. The coral snake, Micrurus fulvius, and the mud snake, Farancia abacura, have both been documented in the preserve (Deb Jansen, National Park Service, oral communication, 2005) but were not detected during our study. Coral snakes are small and difficult to detect using our methods. No coral snakes were detected in ENP in a similar study either (Rice and others, 2004). Mud snakes may be difficult to detect because of their aquatic nature. Only one mud snake was found opportunistically in ENP (Rice and others, 2004). The third snake that was missed, the mangrove salt marsh snake (Nerodia clarkii), may or may not have suitable habitat in BCNP. This species is most often found in estuarine areas. It is possible that it occurs in the southwestern portion of the Preserve, but we have no evidence of this.

The two turtle species that were not detected in the preserve, the Florida mud turtle (Kinosternon subrubrum) and the common musk turtle (Sternotherus odoratus), are both relatively rare in south Florida compared to the striped mud turtle, Kinosternon baurii (Meshaka and others, 2000; Rice and others, 2004). Both of these species may be present in BCNP. They are both more aquatic than the striped mud turtle, and may therefore be less likely to be detected given our sampling methods. Their preferred habitat may be borrow pits and canals, a habitat type that makes up a very small portion of the Preserve and was not sampled during this study.

\section{Summary and Conclusions}

This study represents the first thorough inventory of amphibian species in Big Cypress National Preserve. Work done by Duellman and Schwartz (1958) across south Florida provides a bench mark against which current amphibian distributions can be measured, but it lacks rigorous sampling. Dalyrymple (1995) conducted surveys in the addition lands portion of the preserve, but no sampling of amphibians was conducted in the other management units. Our study provides the first complete list of amphibians for all of Big Cypress National Preserve and it includes the first attempt to estimate the 
relative abundance of populations of each species. We believe, however, that the greatest value of this work is as a baseline for comparison in future monitoring efforts.

One of the goals of this project was to determine if there was evidence of decline in any of the native species of amphibians. No species of amphibian currently known to be present in BCNP appears to be imperiled due to anthropogenic or unknown factors. This is encouraging given the apparent declines of many amphibian species in protected areas worldwide (Alford and Richards, 1999). We detected all of the species of amphibians we anticipated with the exception of one. Hyla femoralis, the pinewoods treefrog, has been previously documented from BCNP (Deb Jansen, National Park Service, oral communication, 2005). We found no proof that the species is present, even after frequent sampling trips to several pineland sites in the northern part of the preserve. It is possible that this species did occur in BCNP in the past, but only in small populations at the southern edge of its range. All of the other amphibian species listed from the preserve were detected and evidence of reproduction was apparent for all anuran species.

Although we did not find any evidence of declines among the amphibian species in BCNP, we do not believe that this means all the amphibian species are without threats. We have identified several potential threats to the amphibian fauna of BCNP. One potential problem is invasive species, especially the Cuban treefrog (Osteopilus septentrionalis). This species has reached very high densities in some protected natural areas in ENP (Rice and others, 2004), and it takes a variety of vertebrate prey (Meshaka 2001; Maskell and others, 2003). The impact to the native treefrog assemblage is under investigation, but it appears that the combination of direct and indirect competition and predation allows Cuban treefrogs to increase to the detriment of native species. The giant toad (Bufo marinus) is another introduced species that appears to be expanding its range in the park. This species is also a voracious predator, and although it is relatively rare in the natural areas of south Florida now, it may be increasing in abundance and expanding its range.

An important management concern that may pose a threat to some amphibian populations is the use of off-road vehicles (ORV) in the preserve. Preliminary analysis of anuran species distributions in BCNP in relation to historic patterns of ORV use suggest that, at a landscape scale, amphibian distribution is influenced by ORV use (J. H. Waddle, U.S Geological Survey, written comm. 2004). This effect is likely beneficial for some species and detrimental to others. We are continuing to conduct research in Big Cypress on the effects of ORV use on amphibians. Hydrologic change due to water management may also impact amphibians. Research to identify the effects of changes in hydropattern and to make predictions about the expected shift in the amphibian community during Everglades restoration is currently underway.

The fact that no amphibian species appear to be declining and that none of the potential threats to amphibians appear to be overwhelming is encouraging. This inventory was designed to serve as a baseline for future monitoring efforts and will help ensure that no amphibian species declines will be unnoticed. The data collected during these surveys provide a snapshot of amphibian species distribution among habitats and across the preserve during 2002-2003. The PAO technique used in this study provides a robust estimate of the true number of sites occupied assuming that not all species are completely detectable. Surveys conducted in a similar manner in the future will be directly comparable because the issue of detectability is explicitly addressed by this type of analysis (MacKenzie and others, 2002).

We recommend that follow-up surveys be conducted on a 5-10 year basis. The surveys should use both VES and vocalization techniques in the field, as neither method alone was sufficient for all species. Sites should be chosen randomly throughout the park. Habitat structure (for example. forested versus nonforested) was one of the most important covariables in modeling site occupancy. Sampling should therefore be stratified by at least this two-category habitat. Sampling conducted during only the warmer, wetter months provides maximum efficiency, because as very little information was added by including the winters in this study. Estimates of proportion of sites occupied with confidence intervals from future monitoring can be directly compared to the estimates from this study. For example, an increase in psi of 0.2 would be interpreted as a 20 percent increase in the number of sites occupied, or vice versa. Although these methods do not allow an estimate of the absolute abundance of amphibians, they do provide a 
convenient surrogate: the abundance of sites occupied by each species. This number is more easily obtained and comparable across time and among different sampling techniques.

\section{Acknowledgments}

We would like to thank the technicians that assisted with the field work in this project: Chris Bugbee, Marquette Crockett, Amber Dove, and Andy Maskell. The Student Conservation Association volunteers of 2002 from Big Cypress also provided valuable assistance. The staff at Big Cypress, especially Deb Jansen, Ron Clark, and Jim Burch provided logistical help, advice, and informative discussions about the natural history of the area. Funding for this project was provided by the National Park Service Inventory and Monitoring Program. Big Cypress National Preserve loaned ATVs, furnished an office, and made housing available to us. Jim Snyder loaned vehicles and accommodation at Raccoon Point. Travel, purchasing, and payroll were managed by the support staff at the University of Florida's Ft. Lauderdale Research and Education Center, especially Sarah Kern, Veronica Woodward, Jocie Graham, Alicia Weinstein, and Valerie Chartier.

\section{Literature Cited}

Alford, R.A., and Richards, S.J. 1999, Global amphibian declines: A problem in applied ecology: Annual Review of Ecology and Systematics vol. 30, p. 133-165.

Burnham, K.P., and Anderson, D.R. 1998, Model selection and multi-model inference: A practical information-theoretic approach: New York, Springer-Verlag.

Carey, C., and Bryant, C.J., 1995, Possible interrelations among environmental toxicants, amphibian development, and decline of amphibian populations: Environmental Health Perspectives v. 103, p. 1317.

Conant, R., and Collins, J.T., 1991, A field guide to reptiles and amphibians: Eastern and central North America, 3rd edition: Houghton Mifflin Company.

Dalrymple, G.H., 1995, Big Cypress National Preserve Addition Lands: Baseline studies: interim report, Miami, Florida International University.

Dodd Jr., C.K., and Cade, B.S., 1998, Movement patterns and the conservation of amphibians breeding in small, temporary wetlands: Conservation Biology v. 12, p. 331-339.

Duellman, W.E., and Schwartz, A., 1958, Amphibians and reptiles of southern Florida: Bulletin of the Florida State Museum, v. 3, p. 179-324.

Heyer, W.R., Donnelly, M.A., McDiarmid, R.W., Hayek, L.C., and Foster, M.S., 1994, Measuring and monitoring biological diversity: Standard methods for amphibians, Washington, D.C., Smithsonian Institution Press.

Hooge, P.N., and Eichenlaub, B., 1997, Animal movement extension to ArcView, in Alaska Science Center - Biological Science Office: Anchorage, Alaska, U.S Geological Survey

MacKenzie, D.I., Nichols, J.D., Hines, J.E., Knutson, M.G., and Franklin, A.B., 2003, Estimating site occupancy, colonization, and local extinction when a species is detected imperfectly: Ecology v. 84, p. 2200-2207.

MacKenzie, D.I., Nichols, J.D., Lachman, G.B., Droege, S., Royle, J.A., and Langtimm, C.A., 2002, Estimating site occupancy rates when detection probabilities are less than one: Ecology v. 83, p. 22482256.

Madden, M., Jones, D., and Vilchek. L, 1999, Photointerpretation key for the Everglades vegetation classification system: Photogrammetric Engineering \& Remote Sensing, v. 65, p. 171-177.

Maskell, A.J., Waddle, J.H., and Rice, K.G. 2003, Osteopilus septentrionalis: Diet: Herpetological Review v. 34, p. 137.

Meshaka, W.E., 2001, The Cuban treefrog in Florida: Gainesville, University of Florida Press. 
Meshaka, W.E., Loftus, W.F., and Steiner, T., 2000, The herpetofauna of Everglades National Park: Florida Scientist v. 63, p. 84-103.

Rice, K.G., Waddle, J.H., Crockett, M.E., Jeffrey, B.M., and Percival, H.F., 2004, Herpetofaunal Inventories of the National Parks of South Florida and the Caribbean: Volume 1. Everglades National Park: U.S. Geological Survey Open-File Report 2004-1065.

Waddle, J.H., Rice, K.G., and Percival, H.F, 2003, Using personal digital assistants to collect wildlife field data: Wildlife Society Bulletin v. 31, p. 306-308. 


\section{Tables}


Table 1. Number of sampling sites and total number of site visits by habitat.

\begin{tabular}{lcc}
\hline \multicolumn{1}{c}{ Habitat } & $\begin{array}{c}\text { Number } \\
\text { of Sites }\end{array}$ & $\begin{array}{c}\text { Number of } \\
\text { Visits }\end{array}$ \\
\hline Cypress & 18 & 105 \\
Cypress Prairie & 17 & 94 \\
Prairie & 32 & 124 \\
Hammock & 12 & 82 \\
Pineland & 25 & 140 \\
\hline Total & 104 & 545 \\
\hline
\end{tabular}


Table 2. The 27 models chosen for testing with each species in program PRESENCE.

\begin{tabular}{ll}
\hline $\begin{array}{l}\text { Occupancy } \\
\text { Rate } \\
\text { Variables }\end{array}$ & $\begin{array}{l}\text { Detection } \\
\text { Probability }\end{array}$ \\
\hline Constant & Constant \\
Constant & 4 Season, Water \\
Constant & 4 Seasons \\
Constant & Humid \\
Constant & Temp \\
Constant & Temp, 4 season \\
Constant & Temp, Humid, Water \\
Constant & Temp, Water \\
Constant & Water \\
2 Habitats & Constant \\
2 Habitats & 4 Season, Water \\
2 Habitats & 4 Seasons \\
2 Habitats & Humid \\
2 Habitats & Temp \\
2 Habitats & Temp, 4 season \\
2 Habitats & Temp, Humid, Water \\
2 Habitats & Temp, Water \\
2 Habitats & Water \\
6 Habitats & Constant \\
6 Habitats & 4 Season, Water \\
6 Habitats & 4 Seasons \\
6 Habitats & Humid \\
6 Habitats & Temp \\
6 Habitats & Temp, 4 season \\
6 Habitats & Temp, Humid, Water \\
6 Habitats & Temp, Water \\
6 Habitats & Water \\
\hline & \\
\hline
\end{tabular}


Table 3. Mean and range of snout-vent length of amphibians measured during visual encounter survey.

\begin{tabular}{lrlr}
\hline \multicolumn{1}{c}{ Species } & $\begin{array}{c}\text { Number of } \\
\text { Individuals }\end{array}$ & $\begin{array}{c}\text { Mean Snout-Vent } \\
\text { Length (+/- SD) }\end{array}$ & $\begin{array}{c}\text { Range of } \\
\text { Snout-Vent } \\
\text { Length } \\
\text { (mm) }\end{array}$ \\
\hline Bufo quercicus & 2 & $16.5(+/-5.5)$ & $11-22$ \\
Bufo terrestris & 20 & $65.1(+/-3.27$ & $20-97$ \\
Acris gryllus & 20 & $22.95(+/-0.63)$ & $16-28$ \\
Hyla cinerea & 684 & $31.07(+/-0.31)$ & $14-58$ \\
Hyla squirella & 1009 & $20.93(+/-0.14)$ & $9-39$ \\
Osteopilus septentrionalis & 9 & $61.2(+/-5.70)$ & $35-82$ \\
Pseudacris nigrita verrucosa & 3 & $25.3(+/-2.67)$ & $20-28$ \\
Pseudacris occularis & 57 & $13.60(+/-0.22)$ & $10-17$ \\
Eleutherodactylus planirostris & 15 & $19.5(+/-0.86)$ & $14-25$ \\
Gastrophryne carolinensis & 5 & $22.2(+/-2.08)$ & $15-26$ \\
Rana grylio & 20 & $64.35(+/-5.89)$ & $35-114$ \\
Rana sphenocephala & 59 & $54.86(+/-2.32)$ & $28-100$ \\
Notophthalmus viridescens & & & \\
priapicola & 1 & $42(+/-0)$ & $42-42$ \\
\hline
\end{tabular}


Table 4. Number of individuals captured and number of site visits during which at least one individual was heard vocalizing by habitat

\begin{tabular}{|c|c|c|c|}
\hline Habitat & $\begin{array}{l}\text { Individual } \\
\text { captures }\end{array}$ & $\begin{array}{c}\text { Visits with } \\
\text { vocalizations } \\
\text { detected }\end{array}$ & $\begin{array}{c}\text { Number of } \\
\text { visits }\end{array}$ \\
\hline \multicolumn{4}{|c|}{ A. gryllus } \\
\hline Cypress & 11 & 33 & 105 \\
\hline Cypress Prairie & 7 & 39 & 94 \\
\hline Hammock & 0 & 40 & 82 \\
\hline Prairie & 3 & 10 & 124 \\
\hline Pineland & 14 & 46 & 140 \\
\hline Total & 35 & 168 & 545 \\
\hline \multicolumn{4}{|c|}{ Bufo marinus } \\
\hline Cypress & 0 & 0 & 105 \\
\hline Cypress Prairie & 0 & 0 & 94 \\
\hline Hammock & 0 & 0 & 82 \\
\hline Prairie & 0 & 4 & 124 \\
\hline Pineland & 0 & 1 & 140 \\
\hline Total & 0 & 5 & 545 \\
\hline \multicolumn{4}{|c|}{ Bufo quericus } \\
\hline Cypress & 0 & 2 & 105 \\
\hline Cypress Prairie & 0 & 3 & 94 \\
\hline Hammock & 0 & 4 & 82 \\
\hline Prairie & 1 & 1 & 124 \\
\hline Pineland & 1 & 7 & 140 \\
\hline Total & 2 & 17 & 545 \\
\hline \multicolumn{4}{|c|}{ Bufo terrestris } \\
\hline Cypress & 1 & 3 & 105 \\
\hline Cypress Prairie & 0 & 4 & 94 \\
\hline Hammock & 1 & 7 & 82 \\
\hline Prairie & 0 & 3 & 124 \\
\hline Pineland & 18 & 9 & 140 \\
\hline Total & 20 & 26 & 545 \\
\hline \multicolumn{4}{|c|}{ Eleuthrodactylus planirostris } \\
\hline Cypress & 4 & 18 & 105 \\
\hline Cypress Prairie & 2 & 21 & 94 \\
\hline Hammock & 26 & 22 & 82 \\
\hline Prairie & 3 & 36 & 124 \\
\hline Pineland & 4 & 35 & 140 \\
\hline Total & 39 & 132 & 545 \\
\hline \multicolumn{4}{|c|}{ Gastrophryne carolinensis } \\
\hline Cypress & 2 & 3 & 105 \\
\hline Cypress Prairie & 0 & 3 & 94 \\
\hline Hammock & 4 & 2 & 82 \\
\hline Prairie & 0 & 0 & 124 \\
\hline Pineland & 2 & 8 & 140 \\
\hline
\end{tabular}




\begin{tabular}{|c|c|c|c|}
\hline Habitat & $\begin{array}{c}\text { Individual } \\
\text { captures }\end{array}$ & $\begin{array}{c}\text { Visits with } \\
\text { vocalizations } \\
\text { detected }\end{array}$ & $\begin{array}{c}\text { Number of } \\
\text { visits }\end{array}$ \\
\hline Total & 8 & 16 & 545 \\
\hline \multicolumn{4}{|c|}{ Hyla cinerea } \\
\hline Cypress & 116 & 23 & 105 \\
\hline Cypress Prairie & 150 & 25 & 94 \\
\hline Hammock & 125 & 18 & 82 \\
\hline Prairie & 251 & 20 & 124 \\
\hline Pineland & 155 & 33 & 140 \\
\hline Total & 797 & 119 & 545 \\
\hline \multicolumn{4}{|c|}{ Hyla gratiosa } \\
\hline Cypress & 0 & 0 & 105 \\
\hline Cypress Prairie & 0 & 0 & 94 \\
\hline Hammock & 0 & 1 & 82 \\
\hline Prairie & 0 & 0 & 124 \\
\hline Pineland & 0 & 2 & 140 \\
\hline Total & 0 & 3 & 545 \\
\hline \multicolumn{4}{|c|}{ Hyla squirella } \\
\hline Cypress & 213 & 8 & 105 \\
\hline Cypress Prairie & 93 & 10 & 94 \\
\hline Hammock & 164 & 9 & 82 \\
\hline Prairie & 125 & 14 & 124 \\
\hline Pineland & 549 & 19 & 140 \\
\hline Total & 1144 & 60 & 545 \\
\hline \multicolumn{4}{|c|}{ Osteopilus septentrionalis } \\
\hline Cypress & 0 & 0 & 105 \\
\hline Cypress Prairie & 0 & 1 & 94 \\
\hline Hammock & 12 & 2 & 82 \\
\hline Prairie & 0 & 1 & 124 \\
\hline Pineland & 0 & 1 & 140 \\
\hline Total & 12 & 5 & 545 \\
\hline \multicolumn{4}{|c|}{ Pseudacris nigrita } \\
\hline Cypress & 2 & 3 & 105 \\
\hline Cypress Prairie & 3 & 3 & 94 \\
\hline Hammock & 0 & 6 & 82 \\
\hline Prairie & 0 & 3 & 124 \\
\hline Pineland & 0 & 10 & 140 \\
\hline Total & 5 & 25 & 545 \\
\hline \multicolumn{4}{|c|}{ Pseudacris occularis } \\
\hline Cypress & 10 & 3 & 105 \\
\hline Cypress Prairie & 13 & 5 & 94 \\
\hline Hammock & 12 & 0 & 82 \\
\hline Prairie & 37 & 15 & 124 \\
\hline Pineland & 25 & 31 & 140 \\
\hline Total & 97 & 54 & 545 \\
\hline \multicolumn{4}{|c|}{ Rana grylio } \\
\hline Cypress & 5 & 39 & 105 \\
\hline
\end{tabular}




\begin{tabular}{|c|c|c|c|}
\hline Habitat & $\begin{array}{l}\text { Individual } \\
\text { captures }\end{array}$ & $\begin{array}{c}\text { Visits with } \\
\text { vocalizations } \\
\text { detected }\end{array}$ & $\begin{array}{l}\text { Number of } \\
\text { visits }\end{array}$ \\
\hline Cypress Prairie & 10 & 40 & 94 \\
\hline Hammock & 20 & 43 & 82 \\
\hline Prairie & 5 & 28 & 124 \\
\hline Pineland & 12 & 45 & 140 \\
\hline Total & 52 & 195 & 545 \\
\hline \multicolumn{4}{|c|}{ Rana sphenocephala } \\
\hline Cypress & 36 & 16 & 105 \\
\hline Cypress Prairie & 25 & 8 & 94 \\
\hline Hammock & 31 & 40 & 82 \\
\hline Prairie & 15 & 5 & 124 \\
\hline Pineland & 35 & 18 & 140 \\
\hline Total & 142 & 87 & 545 \\
\hline
\end{tabular}


Table 5. Months in 2002-2003 during which individuals were detected by VES methods and vocalization. [VES, Visual Encounter Survey]

\begin{tabular}{|c|c|c|c|c|c|c|c|c|c|c|c|c|}
\hline Survey & Jan. & Feb. & Mar. & April & May & June & July & Aug. & Sept. & Oct. & Nov. & Dec. \\
\hline \multicolumn{13}{|c|}{ Acris gryllus } \\
\hline VES & & & $\mathrm{X}$ & & & $\mathrm{X}$ & & $\mathrm{X}$ & & $\mathrm{X}$ & & $\mathrm{X}$ \\
\hline Vocalization & $\mathrm{X}$ & & $\mathrm{X}$ & $\mathrm{X}$ & $\mathrm{X}$ & $\mathrm{X}$ & $\mathrm{X}$ & $\mathrm{X}$ & & $\mathrm{X}$ & & $\mathrm{X}$ \\
\hline \multicolumn{13}{|c|}{ Bufo marinus } \\
\hline \multicolumn{13}{|l|}{ VES } \\
\hline Vocalization & $\mathrm{X}$ & & & & & $\mathrm{X}$ & $\mathrm{X}$ & $\mathrm{X}$ & & & & $\mathrm{X}$ \\
\hline \multicolumn{13}{|c|}{ Bufo quercicus } \\
\hline VES & & & & & & & $\mathrm{X}$ & & & $\mathrm{X}$ & & \\
\hline Vocalization & $\mathrm{X}$ & & $\mathrm{X}$ & & $\mathrm{X}$ & $\mathrm{X}$ & & & & & & \\
\hline \multicolumn{13}{|c|}{ Bufo terrestris } \\
\hline VES & & & $\mathrm{X}$ & $\mathrm{X}$ & $\mathrm{X}$ & & & & & & & \\
\hline Vocalization & & & $\mathrm{X}$ & $\mathrm{X}$ & $\mathrm{X}$ & $\mathrm{X}$ & $\mathrm{X}$ & & $\mathrm{X}$ & & & $\mathrm{X}$ \\
\hline \multicolumn{13}{|c|}{ Eleuthrodactylus planirostris } \\
\hline VES & & $\mathrm{X}$ & $\mathrm{X}$ & $\mathrm{X}$ & $\mathrm{X}$ & $\mathrm{X}$ & $\mathrm{X}$ & $\mathrm{X}$ & $\mathrm{X}$ & $\mathrm{X}$ & $\mathrm{X}$ & $\mathrm{X}$ \\
\hline Vocalization & & & $\mathrm{X}$ & $\mathrm{X}$ & $\mathrm{X}$ & $\mathrm{X}$ & $\mathrm{X}$ & $\mathrm{X}$ & $\mathrm{X}$ & $\mathrm{X}$ & $\mathrm{X}$ & \\
\hline \multicolumn{13}{|c|}{ Gastrophryne carolinensis } \\
\hline VES & & & $\mathrm{X}$ & $\mathrm{X}$ & $\mathrm{X}$ & & & & & & & \\
\hline Vocalization & & & $\mathrm{X}$ & & & $\mathrm{X}$ & $\mathrm{X}$ & $\mathrm{X}$ & & & $\mathrm{X}$ & \\
\hline \multicolumn{13}{|c|}{ Hyla cinerea } \\
\hline VES & $\mathrm{X}$ & $\mathrm{X}$ & $\mathrm{X}$ & $\mathrm{X}$ & $\mathrm{X}$ & $\mathrm{X}$ & $\mathrm{X}$ & $\mathrm{X}$ & $\mathrm{X}$ & $\mathrm{X}$ & $\mathrm{X}$ & $\mathrm{X}$ \\
\hline Vocalization & & & $\mathrm{X}$ & $\mathrm{X}$ & $\mathrm{X}$ & $\mathrm{X}$ & $\mathrm{X}$ & $\mathrm{X}$ & $\mathrm{X}$ & $\mathrm{X}$ & & $\mathrm{X}$ \\
\hline \multicolumn{13}{|c|}{ Hyla gratiosa } \\
\hline \multicolumn{13}{|l|}{ VES } \\
\hline Vocalization & & & & & & & & $\mathrm{X}$ & & & & \\
\hline \multicolumn{13}{|c|}{ Hyla squirella } \\
\hline VES & $\mathrm{X}$ & $\mathrm{X}$ & $\mathrm{X}$ & $\mathrm{X}$ & $\mathrm{X}$ & $\mathrm{X}$ & $\mathrm{X}$ & $\mathrm{X}$ & $\mathrm{X}$ & $\mathrm{X}$ & $\mathrm{X}$ & $\mathrm{X}$ \\
\hline Vocalization & & & $\mathrm{X}$ & $\mathrm{X}$ & $\mathrm{X}$ & $\mathrm{X}$ & $\mathrm{X}$ & $\mathrm{X}$ & & & & \\
\hline \multicolumn{13}{|c|}{ Osteopilus septentrionalis } \\
\hline VES & $\mathrm{X}$ & $\mathrm{X}$ & & & $\mathrm{X}$ & $\mathrm{X}$ & $\mathrm{X}$ & & & $\mathrm{X}$ & $\mathrm{X}$ & $\mathrm{X}$ \\
\hline Vocalization & & & & $\mathrm{X}$ & & & $\mathrm{X}$ & $\mathrm{X}$ & $\mathrm{X}$ & & & \\
\hline \multicolumn{13}{|c|}{ Pseudacris nigrita } \\
\hline VES & & & $\mathrm{X}$ & & & $\mathrm{X}$ & & & $\mathrm{X}$ & & & $\mathrm{X}$ \\
\hline Vocalization & & & $\mathrm{X}$ & $\mathrm{X}$ & $\mathrm{X}$ & $\mathrm{X}$ & & & & & & $\mathrm{X}$ \\
\hline \multicolumn{13}{|c|}{ Pseudacris occularis } \\
\hline VES & $\mathrm{X}$ & $\mathrm{X}$ & $\mathrm{X}$ & $\mathrm{X}$ & $\mathrm{X}$ & $\mathrm{X}$ & $\mathrm{X}$ & $\mathrm{X}$ & $\mathrm{X}$ & $\mathrm{X}$ & $\mathrm{X}$ & $\mathrm{X}$ \\
\hline Vocalization & & & & & $\mathrm{X}$ & $\mathrm{X}$ & $\mathrm{X}$ & $\mathrm{X}$ & $\mathrm{X}$ & & & $\mathrm{X}$ \\
\hline \multicolumn{13}{|c|}{ Rana grylio } \\
\hline VES & $\mathrm{X}$ & $\mathrm{X}$ & $\mathrm{X}$ & $\mathrm{X}$ & $\mathrm{X}$ & $\mathrm{X}$ & $\mathrm{X}$ & $\mathrm{X}$ & $\mathrm{X}$ & $\mathrm{X}$ & $\mathrm{X}$ & $\mathrm{X}$ \\
\hline Vocalization & $\mathrm{X}$ & $\mathrm{X}$ & $\mathrm{X}$ & $\mathrm{X}$ & $\mathrm{X}$ & $\mathrm{X}$ & $\mathrm{X}$ & $\mathrm{X}$ & $\mathrm{X}$ & $\mathrm{X}$ & $\mathrm{X}$ & $\mathrm{X}$ \\
\hline \multicolumn{13}{|c|}{ Rana sphenocephala } \\
\hline VES & $\mathrm{X}$ & $\mathrm{X}$ & $\mathrm{X}$ & $\mathrm{X}$ & $\mathrm{X}$ & $\mathrm{X}$ & $\mathrm{X}$ & $\mathrm{X}$ & $\mathrm{X}$ & $\mathrm{X}$ & $\mathrm{X}$ & $\mathrm{X}$ \\
\hline Vocalization & $\mathrm{X}$ & $\mathrm{X}$ & & $\mathrm{X}$ & & $\mathrm{X}$ & $\mathrm{X}$ & $\mathrm{X}$ & $\mathrm{X}$ & $\mathrm{X}$ & $\mathrm{X}$ & $\mathrm{X}$ \\
\hline
\end{tabular}


Table 6. Average snout-vent length for individuals found using VES and opportunistic encounter surveys

(stratified by habitat).

\begin{tabular}{|c|c|c|c|}
\hline Habitat & $\begin{array}{l}\text { Individuals } \\
\text { measured } \\
\text { (N) }\end{array}$ & $\begin{array}{l}\text { Mean snout- } \\
\text { vent length } \\
(\mathrm{mm})\end{array}$ & $\begin{array}{l}\text { Standard } \\
\text { deviation }\end{array}$ \\
\hline \multicolumn{4}{|c|}{ Acris gryllus } \\
\hline Cypress & 5 & 21.6 & 0.93 \\
\hline Cypress Prairie & 5 & 24.4 & 1.12 \\
\hline Hammock & 0 & N/A & N/A \\
\hline Prairie & 0 & N/A & N/A \\
\hline Pineland & 10 & 22.9 & 1 \\
\hline \multicolumn{4}{|c|}{ Bufo quercicus } \\
\hline Cypress & 0 & N/A & N/A \\
\hline Cypress Prairie & 0 & N/A & N/A \\
\hline Hammock & 0 & N/A & N/A \\
\hline Prairie & 1 & 11 & 0 \\
\hline Pineland & 1 & 22 & 0 \\
\hline \multicolumn{4}{|c|}{ Bufo terrestris } \\
\hline Cypress & 0 & 58 & 0 \\
\hline Cypress Prairie & 0 & N/A & N/A \\
\hline Hammock & 1 & 20 & 0 \\
\hline Prairie & 0 & N/A & N/A \\
\hline Pineland & 10 & 57.2 & 4.15 \\
\hline \multicolumn{4}{|c|}{ Eleuthrodactylus planirostris } \\
\hline Cypress & 2 & 22 & 1 \\
\hline Cypress Prairie & 1 & 15 & 0 \\
\hline Hammock & 9 & 18.89 & 1.12 \\
\hline Prairie & 1 & 23 & 0 \\
\hline Pineland & 2 & 20.5 & 2.5 \\
\hline \multicolumn{4}{|c|}{ Gastrophryne carolinensis } \\
\hline Cypress & 2 & 25 & 0 \\
\hline Cypress Prairie & 0 & N/A & N/A \\
\hline Hammock & 2 & 20.5 & 5.5 \\
\hline Prairie & 0 & $\mathrm{~N} / \mathrm{A}$ & N/A \\
\hline Pineland & 1 & 20 & 0 \\
\hline \multicolumn{4}{|c|}{ Hyla cinerea } \\
\hline Cypress & 97 & 31.09 & 0.89 \\
\hline Cypress Prairie & 126 & 33.17 & 0.66 \\
\hline Hammock & 111 & 35.10 & 0.82 \\
\hline Prairie & 212 & 27.95 & 0.40 \\
\hline Pineland & 138 & 30.70 & 0.79 \\
\hline \multicolumn{4}{|c|}{ Hyla squirella } \\
\hline Cypress & 195 & 21.68 & 0.32 \\
\hline Cypress Prairie & 86 & 22.06 & 0.43 \\
\hline Hammock & 152 & 23.26 & 0.34 \\
\hline Prairie & 114 & 20.25 & 0.40 \\
\hline Pineland & 462 & 19.81 & 0.21 \\
\hline
\end{tabular}




\begin{tabular}{|c|c|c|c|}
\hline Habitat & $\begin{array}{l}\text { Individuals } \\
\text { measured } \\
\text { (N) }\end{array}$ & $\begin{array}{l}\text { Mean snout- } \\
\text { vent length } \\
(\mathrm{mm})\end{array}$ & $\begin{array}{l}\text { Standard } \\
\text { deviation }\end{array}$ \\
\hline \multicolumn{4}{|c|}{ steopilus septentrionalis } \\
\hline Cypress & 0 & N/A & N/A \\
\hline Cypress Prairie & 0 & N/A & N/A \\
\hline Hammock & 9 & 61.20 & 5.69 \\
\hline Prairie & 0 & N/A & N/A \\
\hline Pineland & 0 & N/A & N/A \\
\hline \multicolumn{4}{|c|}{ Pseudacris nigrita } \\
\hline Cypress & 1 & 20 & 0 \\
\hline Cypress Prairie & 2 & 28 & 0 \\
\hline Hammock & 0 & N/A & N/A \\
\hline Prairie & 0 & N/A & N/A \\
\hline Pineland & 0 & N/A & N/A \\
\hline \multicolumn{4}{|c|}{ Pseudacris occularis } \\
\hline Cypress & 4 & 13.25 & 0.85 \\
\hline Cypress Prairie & 8 & 14.13 & 0.35 \\
\hline Hammock & 10 & 13.90 & 0.41 \\
\hline Prairie & 22 & 13.18 & 0.40 \\
\hline Pineland & 13 & 13.85 & 0.49 \\
\hline \multicolumn{4}{|c|}{ Rana grylio } \\
\hline Cypress & 1 & 35 & 0 \\
\hline Cypress Prairie & 4 & 77.75 & 12.43 \\
\hline Hammock & 8 & 59.88 & 9.26 \\
\hline Prairie & 0 & N/A & N/A \\
\hline Pineland & 7 & 66 & 10.67 \\
\hline \multicolumn{4}{|c|}{ Rana sphenocephala } \\
\hline Cypress & 16 & 52.69 & 4.07 \\
\hline Cypress Prairie & 8 & 62.50 & 6.94 \\
\hline Hammock & 10 & 50.40 & 5.32 \\
\hline Marsh & 5 & 65.20 & 9.83 \\
\hline Pineland & 20 & 53.20 & 3.96 \\
\hline
\end{tabular}


Table 7. Number of sites sampled, sites at which individuals were detected, and the minimum (naïve) and PAO estimate of the site occupancy rate by habitat.

[PAO, Percent of area occupied

\begin{tabular}{|c|c|c|c|c|}
\hline Habitat & $\begin{array}{l}\text { Number } \\
\text { of sites }\end{array}$ & $\begin{array}{l}\text { Number of } \\
\text { sites with } \\
\text { detection }\end{array}$ & $\begin{array}{c}\text { Naïve } \\
\text { occupancy } \\
\text { rate } \\
\text { (percent) }\end{array}$ & $\begin{array}{c}\text { PAO } \\
\text { estimate } \\
\text { (percent) }\end{array}$ \\
\hline \multicolumn{5}{|c|}{ Acris gryllus } \\
\hline Cypress & 18 & 15 & 83.33 & 100.00 \\
\hline Cypress Prairie & 17 & 15 & 88.24 & 100.00 \\
\hline Hammock & 12 & 8 & 66.67 & 86.31 \\
\hline Prairie & 32 & 22 & 68.75 & 95.24 \\
\hline Pineland & 25 & 20 & 80.00 & 100.00 \\
\hline Total & 104 & 80 & 76.92 & 96.80 \\
\hline \multicolumn{5}{|c|}{ Bufo quercicus } \\
\hline Cypress & 18 & 1 & 5.56 & 23.32 \\
\hline Cypress Prairie & 17 & 3 & 17.65 & 81.18 \\
\hline Hammock & 12 & 1 & 8.33 & 25.23 \\
\hline Prairie & 32 & 5 & 15.63 & 74.85 \\
\hline Pineland & 25 & 5 & 20.00 & 90.41 \\
\hline Total & 104 & 15 & 14.42 & 65.22 \\
\hline \multicolumn{5}{|c|}{ Bufo terrestris } \\
\hline Cypress & 18 & 4 & 22.22 & 68.41 \\
\hline Cypress Prairie & 17 & 2 & 11.76 & 45.39 \\
\hline Hammock & 12 & 3 & 25.00 & 80.26 \\
\hline Prairie & 32 & 5 & 15.63 & 100.00 \\
\hline Pineland & 25 & 8 & 32.00 & 91.83 \\
\hline Total & 104 & 22 & 21.15 & 90.16 \\
\hline \multicolumn{5}{|c|}{ Eleuthrodactylus planirostris } \\
\hline Cypress & 18 & 10 & 55.56 & 81.20 \\
\hline Cypress Prairie & 17 & 8 & 47.06 & 77.20 \\
\hline Hammock & 12 & 10 & 83.33 & 100.00 \\
\hline Prairie & 32 & 7 & 21.88 & 89.66 \\
\hline Pineland & 25 & 17 & 68.00 & 66.50 \\
\hline Total & 104 & 52 & 50.00 & 83.02 \\
\hline \multicolumn{5}{|c|}{ Gastrophryne carolinensis } \\
\hline Cypress & 18 & 5 & 27.78 & 76.92 \\
\hline Cypress Prairie & 17 & 2 & 11.76 & 37.25 \\
\hline Hammock & 12 & 3 & 25.00 & 78.18 \\
\hline Prairie & 32 & 2 & 6.25 & 100.00 \\
\hline Pineland & 25 & 9 & 36.00 & 36.00 \\
\hline Total & 104 & 21 & 20.19 & 62.81 \\
\hline \multicolumn{5}{|c|}{ Hyla cinerea } \\
\hline Cypress & 18 & 18 & 100.00 & 100.00 \\
\hline Cypress Prairie & 17 & 17 & 100.00 & 100.00 \\
\hline Hammock & 12 & 12 & 100.00 & 100.00 \\
\hline Prairie & 32 & 21 & 65.63 & 100.00 \\
\hline
\end{tabular}




\begin{tabular}{|c|c|c|c|c|}
\hline Habitat & $\begin{array}{l}\text { Number } \\
\text { of sites }\end{array}$ & $\begin{array}{l}\text { Number of } \\
\text { sites with } \\
\text { detection }\end{array}$ & $\begin{array}{c}\text { Naïve } \\
\text { occupancy } \\
\text { rate } \\
\text { (percent) }\end{array}$ & $\begin{array}{c}\text { PAO } \\
\text { estimate } \\
\text { (percent) }\end{array}$ \\
\hline Pineland & 25 & 23 & 92.00 & 82.55 \\
\hline Total & 104 & 91 & 87.50 & 98.68 \\
\hline \multicolumn{5}{|c|}{ Hyla squirella } \\
\hline Cypress & 18 & 13 & 72.22 & 82.30 \\
\hline Cypress Prairie & 17 & 10 & 58.82 & 70.19 \\
\hline Hammock & 12 & 11 & 91.67 & 100.00 \\
\hline Marsh & 32 & 12 & 37.50 & 100.00 \\
\hline Pineland & 25 & 23 & 92.00 & 51.49 \\
\hline Total & 104 & 69 & 66.35 & 79.98 \\
\hline \multicolumn{5}{|c|}{ Osteopilus septentrionalis } \\
\hline Cypress & 18 & 0 & 0.00 & 0.00 \\
\hline Cypress Prairie & 17 & 1 & 5.88 & 10.05 \\
\hline Hammock & 12 & 2 & 16.67 & 29.65 \\
\hline Prairie & 32 & 2 & 6.25 & 16.59 \\
\hline Pineland & 25 & 1 & 4.00 & 13.27 \\
\hline Total & 104 & 6 & 5.77 & 13.05 \\
\hline \multicolumn{5}{|c|}{ Pseudacris nigrita } \\
\hline Cypress & 18 & 4 & 22.22 & 58.21 \\
\hline Cypress Prairie & 17 & 3 & 17.65 & 67.86 \\
\hline Hammock & 12 & 3 & 25.00 & 69.98 \\
\hline Prairie & 32 & 3 & 9.38 & 58.02 \\
\hline Pineland & 25 & 5 & 20.00 & 40.10 \\
\hline Total & 104 & 18 & 17.31 & 55.08 \\
\hline \multicolumn{5}{|c|}{ Pseudacris ocularis } \\
\hline Cypress & 18 & 4 & 22.22 & 35.70 \\
\hline Cypress Prairie & 17 & 5 & 29.41 & 55.18 \\
\hline Hammock & 12 & 3 & 25.00 & 31.19 \\
\hline Prairie & 32 & 4 & 12.50 & 40.59 \\
\hline Pineland & 25 & 13 & 52.00 & 81.68 \\
\hline Total & 104 & 29 & 27.88 & 48.02 \\
\hline \multicolumn{5}{|c|}{ Rana grylio } \\
\hline Cypress & 18 & 16 & 88.89 & NA \\
\hline Cypress Prairie & 17 & 15 & 88.24 & NA \\
\hline Hammock & 12 & 11 & 91.67 & NA \\
\hline Prairie & 32 & 21 & 65.63 & NA \\
\hline Pineland & 25 & 21 & 84.00 & NA \\
\hline Total & 104 & 84 & 80.77 & 99.96 \\
\hline \multicolumn{5}{|c|}{ Rana sphenocephala } \\
\hline Cypress & 18 & 14 & 77.78 & 100.00 \\
\hline Cypress Prairie & 17 & 13 & 76.47 & 93.33 \\
\hline Hammock & 12 & 9 & 75.00 & 100.00 \\
\hline Prairie & 32 & 27 & 84.38 & 99.51 \\
\hline Pineland & 25 & 16 & 64.00 & 100.00 \\
\hline Total & 104 & 79 & 75.96 & 98.79 \\
\hline
\end{tabular}


Table 8. Numbers of individual caudates captured by different survey methods.

\begin{tabular}{lcccc}
\hline \multicolumn{1}{c}{ Survey Method } & $\begin{array}{c}\text { Amphiuma } \\
\text { means }\end{array}$ & $\begin{array}{c}\text { Notophthalmus } \\
\text { viridescens }\end{array}$ & $\begin{array}{c}\text { Pseudobranchus } \\
\text { axanthus }\end{array}$ & $\begin{array}{c}\text { Siren } \\
\text { lacertina }\end{array}$ \\
\hline VES & 4 & 1 & 0 & 0 \\
Opportunistic Encounter & 4 & 3 & 0 & 1 \\
Drift Fences & 0 & 0 & 1 & 7 \\
\hline Total & 8 & 4 & 1 & 8 \\
\hline
\end{tabular}


Table 9. Reptiles believed to potentially occur in Big Cypress National Preserve, whether they are introduced, and whether they were encountered during this study.

\begin{tabular}{|c|c|c|c|}
\hline Class & Species & Introduced & This Study \\
\hline \multirow[t]{2}{*}{ Crocodilians } & Alligator mississippiensis & & $\mathrm{X}$ \\
\hline & Crocodylus acutus & & \\
\hline \multirow[t]{9}{*}{ Lizards } & Anolis carolinensis & & $\mathrm{X}$ \\
\hline & Anolis sagrei & $\mathrm{X}$ & $\mathrm{X}$ \\
\hline & Eumeces inexpectatus & & $\mathrm{X}$ \\
\hline & Hemidactylus garnotii & $\mathrm{X}$ & $\mathrm{X}$ \\
\hline & Hemidactylus mabouia & $\mathrm{X}$ & $\mathrm{X}$ \\
\hline & Hemidactylus tursicus & $\mathrm{X}$ & \\
\hline & Iguana iguana & $\mathrm{X}$ & $\mathrm{X}$ \\
\hline & Ophisaurus compressus & & $\mathrm{X}$ \\
\hline & Scincella lateralis & & $\mathrm{X}$ \\
\hline \multirow[t]{25}{*}{ Snakes } & Agkistrodon piscivorus conanti & & $\mathrm{X}$ \\
\hline & Cemophora coccinea coccinea & & $\mathrm{X}$ \\
\hline & Coluber constrictor paludicola & & $\mathrm{X}$ \\
\hline & Crotalus adamanteus & & $\mathrm{X}$ \\
\hline & Diadophis punctatus punctatus & & $\mathrm{X}$ \\
\hline & Drymarchon corais & & \\
\hline & Elaphe guttata guttata & & $\mathrm{X}$ \\
\hline & Elaphe obsoleta quadrivittata & & $\mathrm{X}$ \\
\hline & Farancia abacura & & \\
\hline & Lampropeltis getula floridana & & $\mathrm{X}$ \\
\hline & Lampropeltis triangulum elapsoides & & $\mathrm{X}$ \\
\hline & Micrurus fulvius & & \\
\hline & Nerodia clarkii & & \\
\hline & Nerodia fasciata pictiventris & & $\mathrm{X}$ \\
\hline & Nerodia floridana & & $\mathrm{X}$ \\
\hline & Nerodia taxispilota & & $\mathrm{X}$ \\
\hline & Opheodrys aestivus & & $\mathrm{X}$ \\
\hline & Python molorus & $\mathrm{X}$ & \\
\hline & Ramphotyphlops braminus & $\mathrm{X}$ & \\
\hline & Regina alleni & & $\mathrm{X}$ \\
\hline & Seminatrix pygea cyclas & & $\mathrm{X}$ \\
\hline & Sistrurus miliarius barbouri & & $\mathrm{X}$ \\
\hline & Storeria dekayi victa & & $\mathrm{X}$ \\
\hline & Thamnophis sauritus sackenii & & $\mathrm{X}$ \\
\hline & Thamnophis sirtalis sirtalis & & $\mathrm{X}$ \\
\hline Turtles & Apolone ferox & & $\mathrm{X}$ \\
\hline
\end{tabular}




\begin{tabular}{llc}
\hline \multicolumn{1}{c}{ Class } & \multicolumn{1}{c}{ Species } & This Study \\
\hline & $\begin{array}{l}\text { Chelydra serpentina osceola } \\
\text { Deirochelys reticularia } \\
\text { Gopherus polyphemus }\end{array}$ & $\mathrm{X}$ \\
Kinosternon baurii & \\
Kinosternon subrubrum & $\mathrm{X}$ \\
& \\
Pseudemys floridana peninsularis & \\
Pseudemys nelsoni & $\mathrm{X}$ \\
Sternotherus odoratus & $\mathrm{X}$ \\
Terrapene carolina baurii & \\
& $\mathrm{X}$ \\
\hline
\end{tabular}


Table 10. Reptile species found in Big Cypress National Preserve and the survey methods by which they were detected

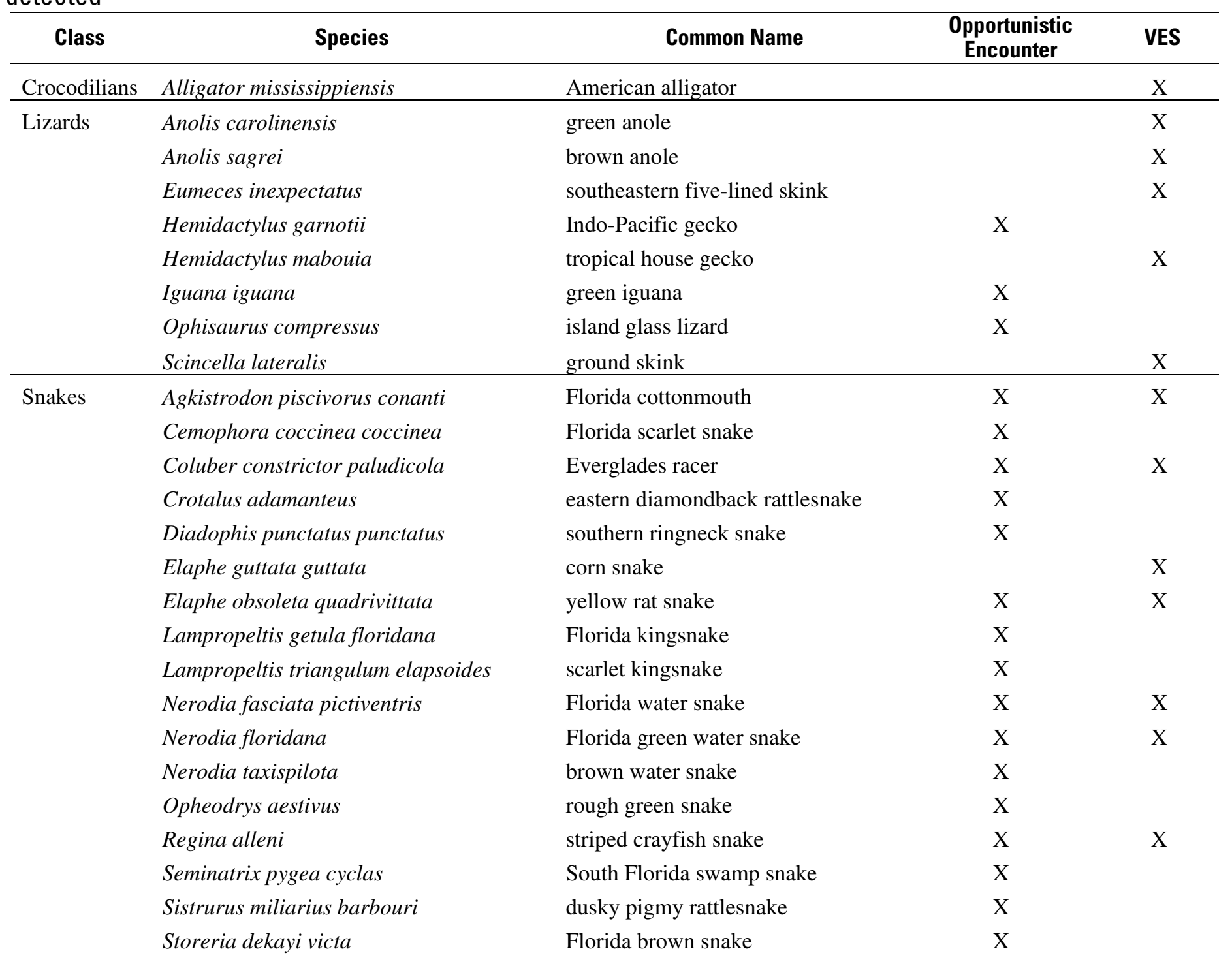




\begin{tabular}{lllcc}
\hline \multicolumn{1}{c}{ Class } & \multicolumn{1}{c}{ Species } & \multicolumn{1}{c}{ Common Name } & $\begin{array}{c}\text { Opportunistic } \\
\text { Encounter }\end{array}$ & VES \\
\hline \multirow{2}{*}{ Turtles } & Thamnophis sauritus sackenii & peninsula ribbon snake & $\mathrm{X}$ & $\mathrm{X}$ \\
& Thamnophis sirtalis sirtalis & eastern garter snake & $\mathrm{X}$ & $\mathrm{X}$ \\
& Apolone ferox & Florida softshell turtle & $\mathrm{X}$ & \\
& Chelydra serpentina osceola & Florida snapping turtle & $\mathrm{X}$ & $\mathrm{X}$ \\
& Deirochelys reticularia & Chicken turtle & $\mathrm{X}$ & \\
& Kinosternon baurii & striped mud turtle & $\mathrm{X}$ & $\mathrm{X}$ \\
& Pseudemys floridana peninsularis & peninsula cooter & $\mathrm{X}$ & $\mathrm{X}$ \\
& Pseudemys nelsoni & Florida redbelly turtle & $\mathrm{X}$ & $\mathrm{X}$ \\
& Terrapene carolina baurii & Florida box turtle & $\mathrm{X}$ & $\mathrm{X}$ \\
\hline
\end{tabular}




\section{Figures}




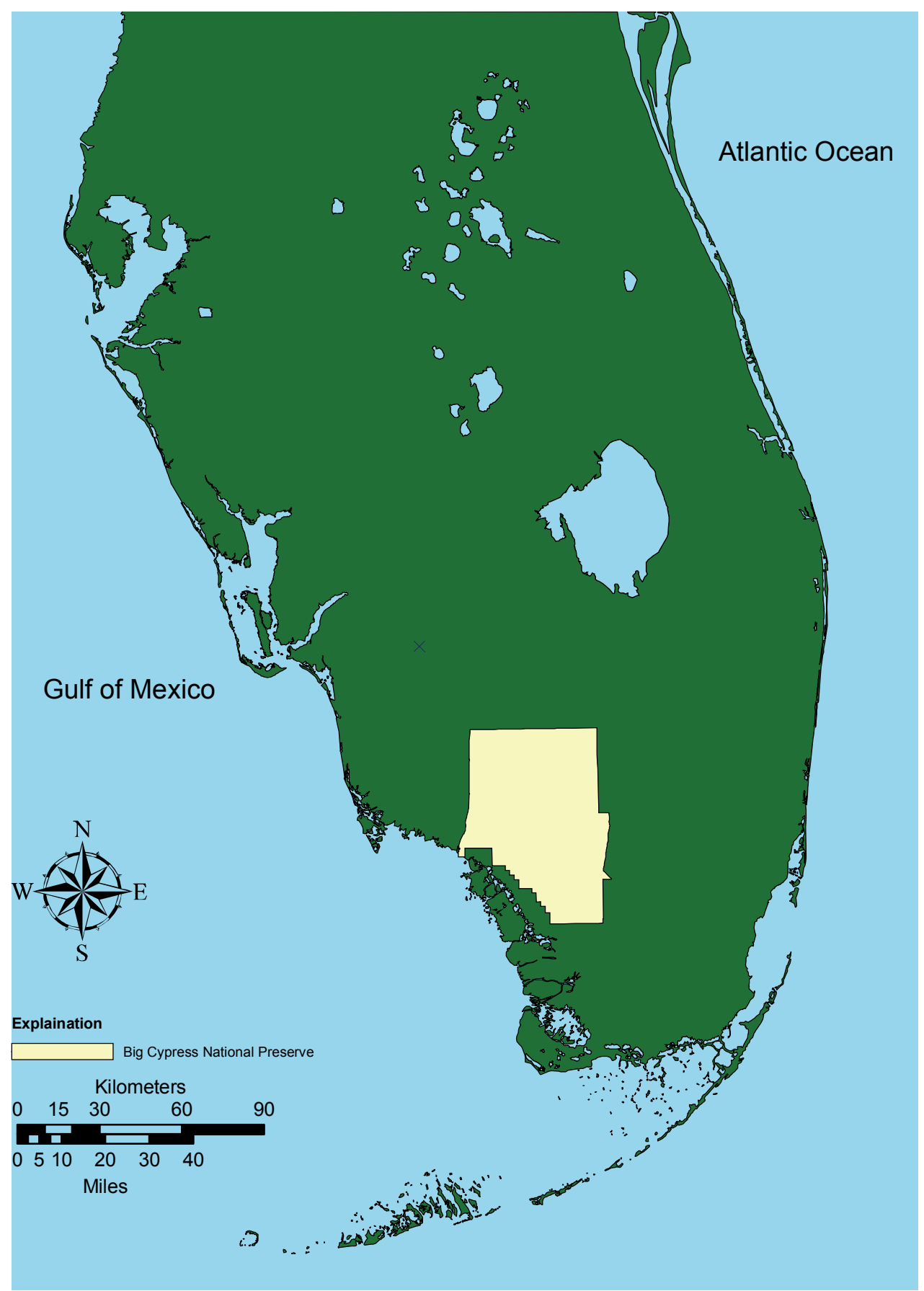

Figure 1. Map of southern Florida showing the location of Big Cypress National Preserve. 


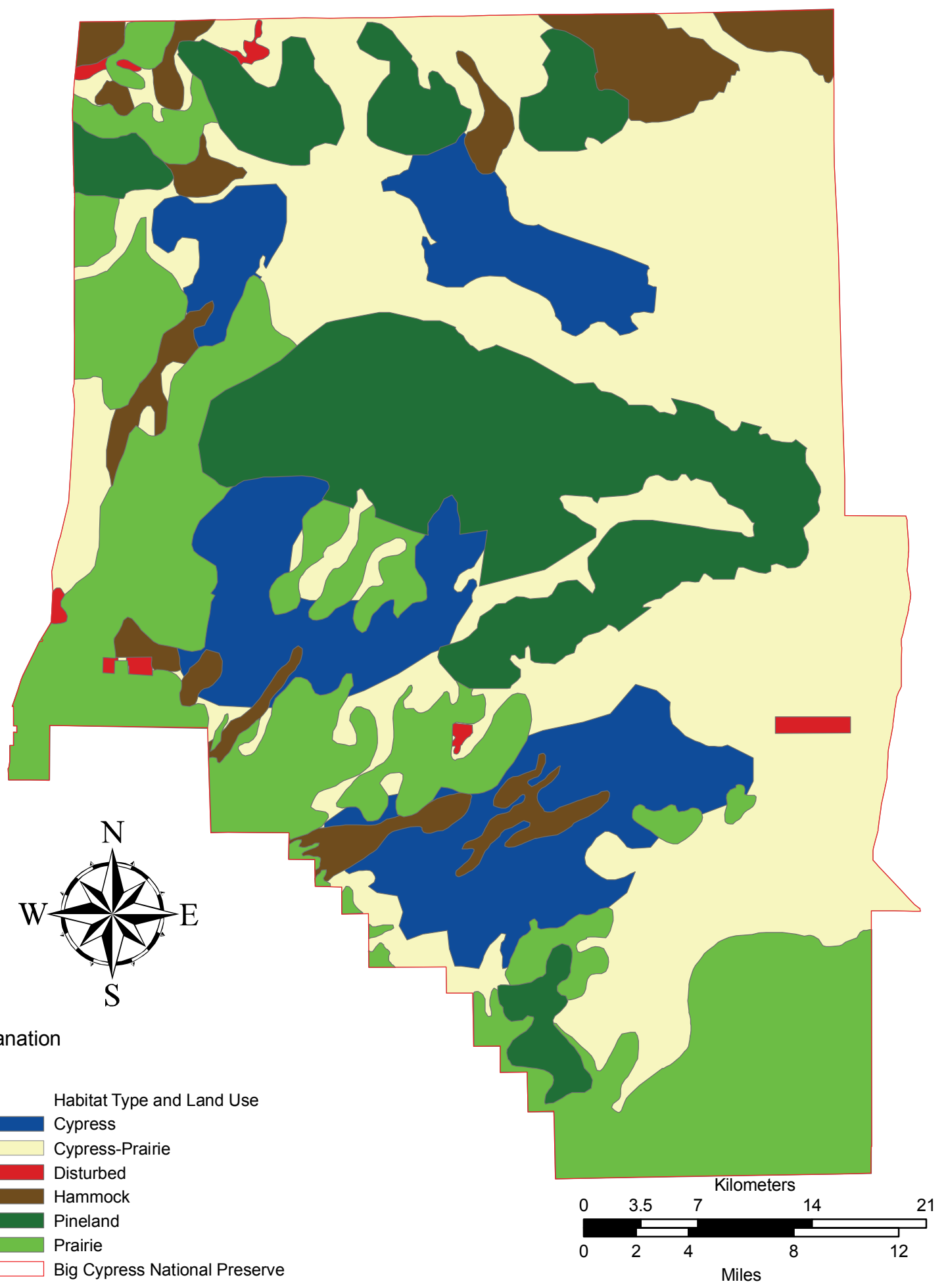

Figure 2. Vegetation classification of Big Cypress National Preserve. 


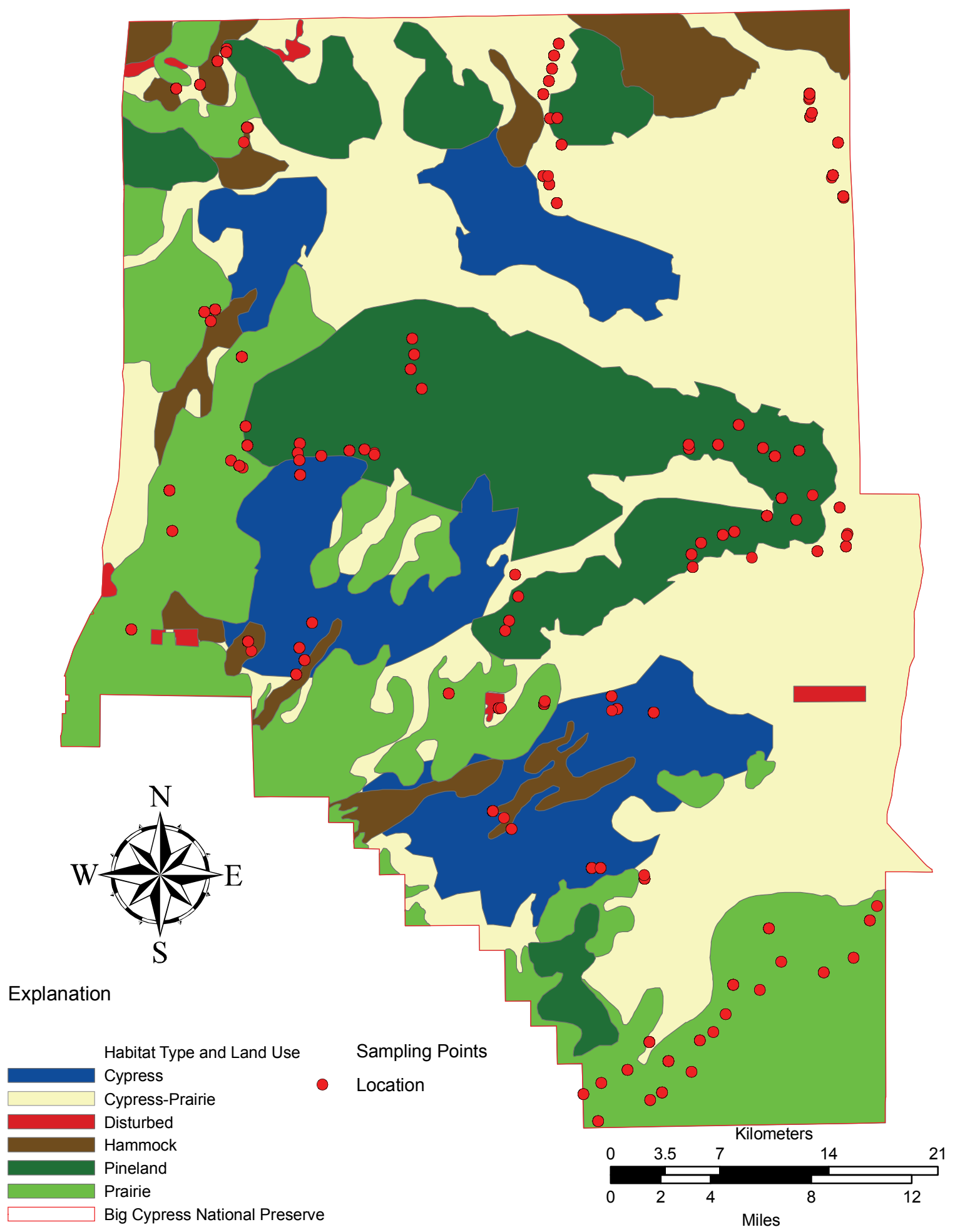

Figure 3. Standard sampling site locations. Map of all standard sampling locations at which VES and vocalization surveys were conducted at Big Cypress National Preserve. 


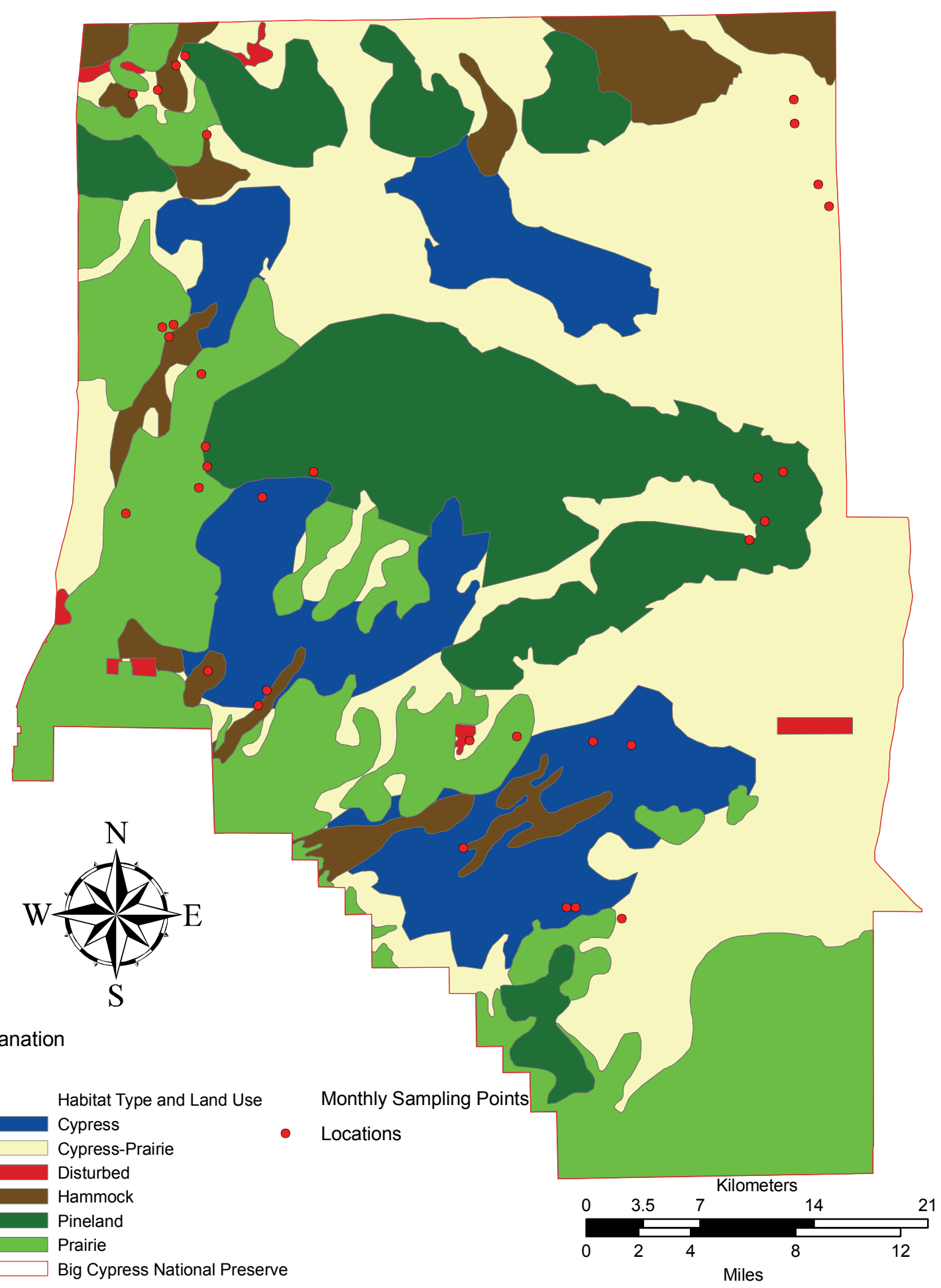

Figure 4. Sites sampled on a monthly basis. Map of all locations at which VES and vocalization surveys were conducted on a monthly basis at Big Cypress National Preserve. 


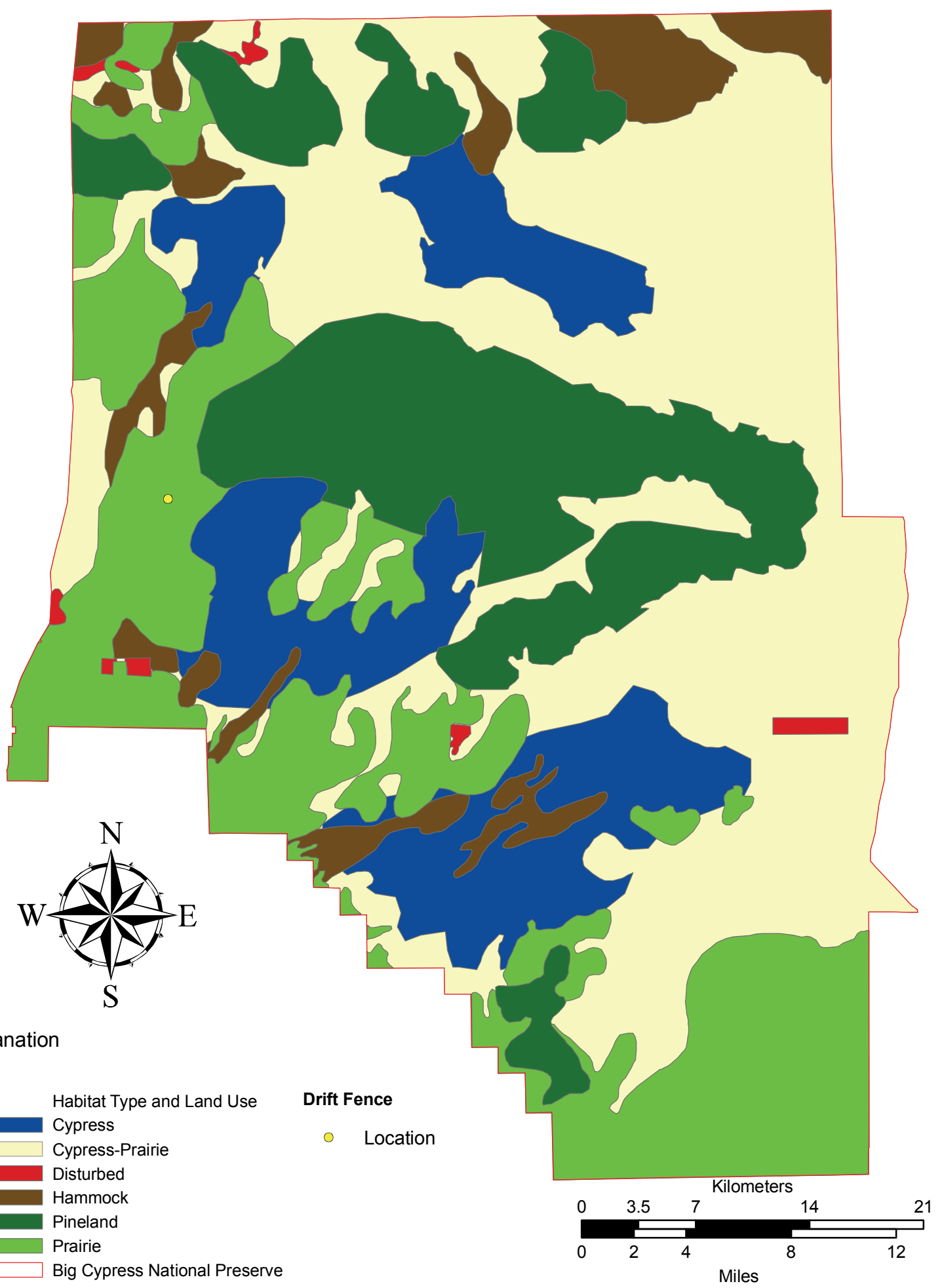

Figure 5. Location of drift fences. Map of the location at which drift fence surveys were conducted at Big Cypress National Preserve. 


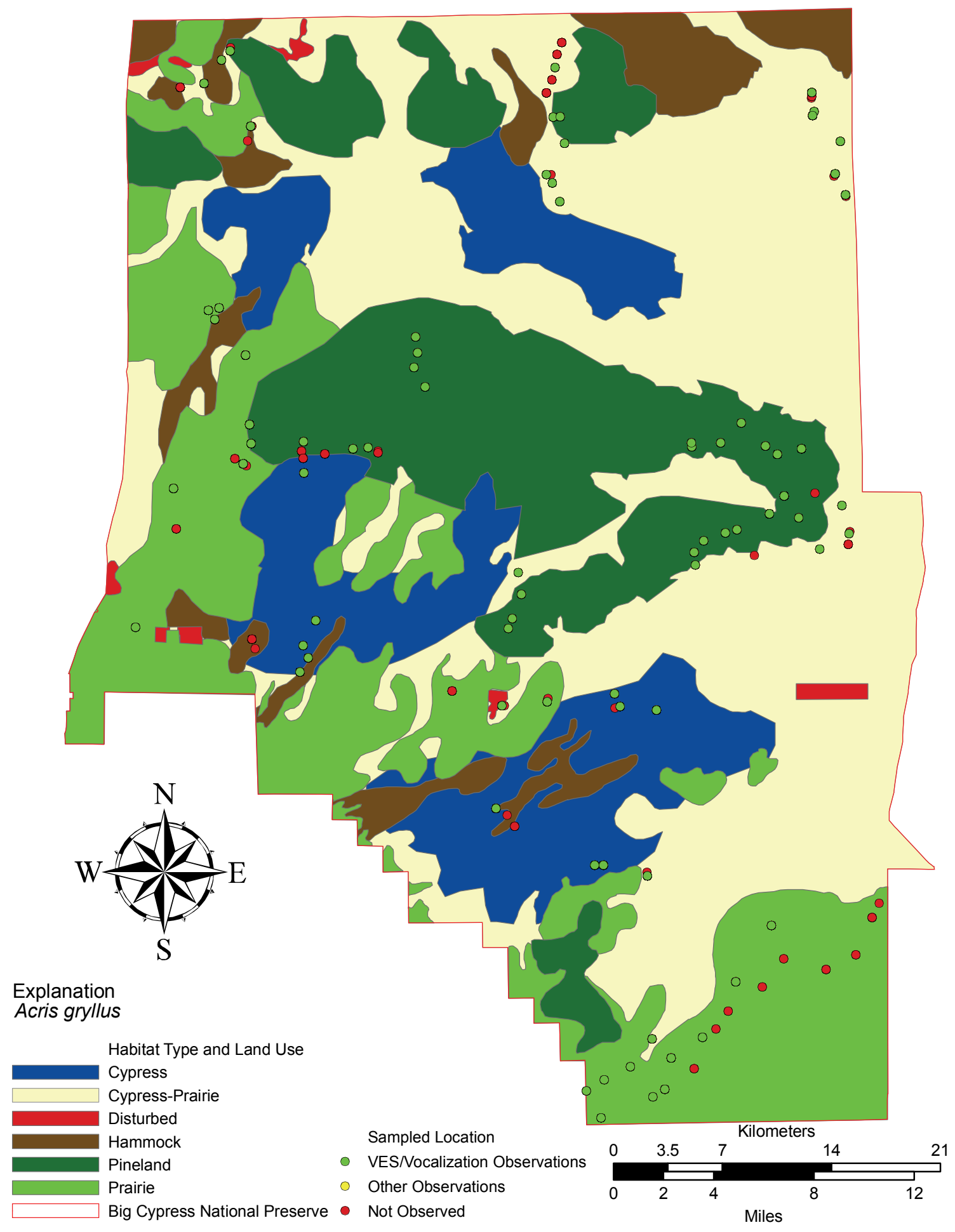

Figure 6. Acris gryllus locations. Map of all locations Acris gryllus were observed in Big Cypress National Preserve. 


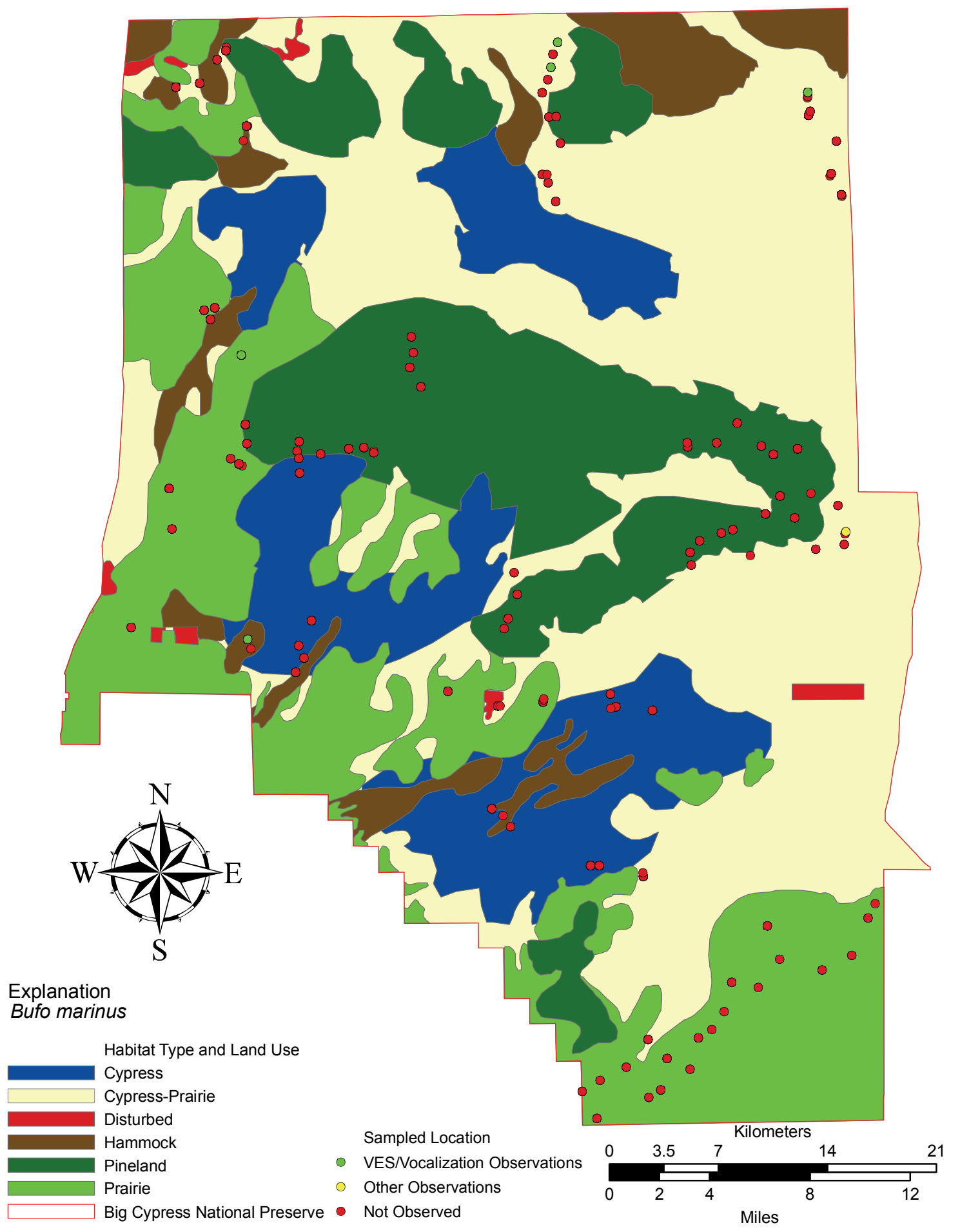

Figure 7. Bufo marinus locations. Map of all locations at which Bufo marinus were observed in Big Cypress National Preserve. 


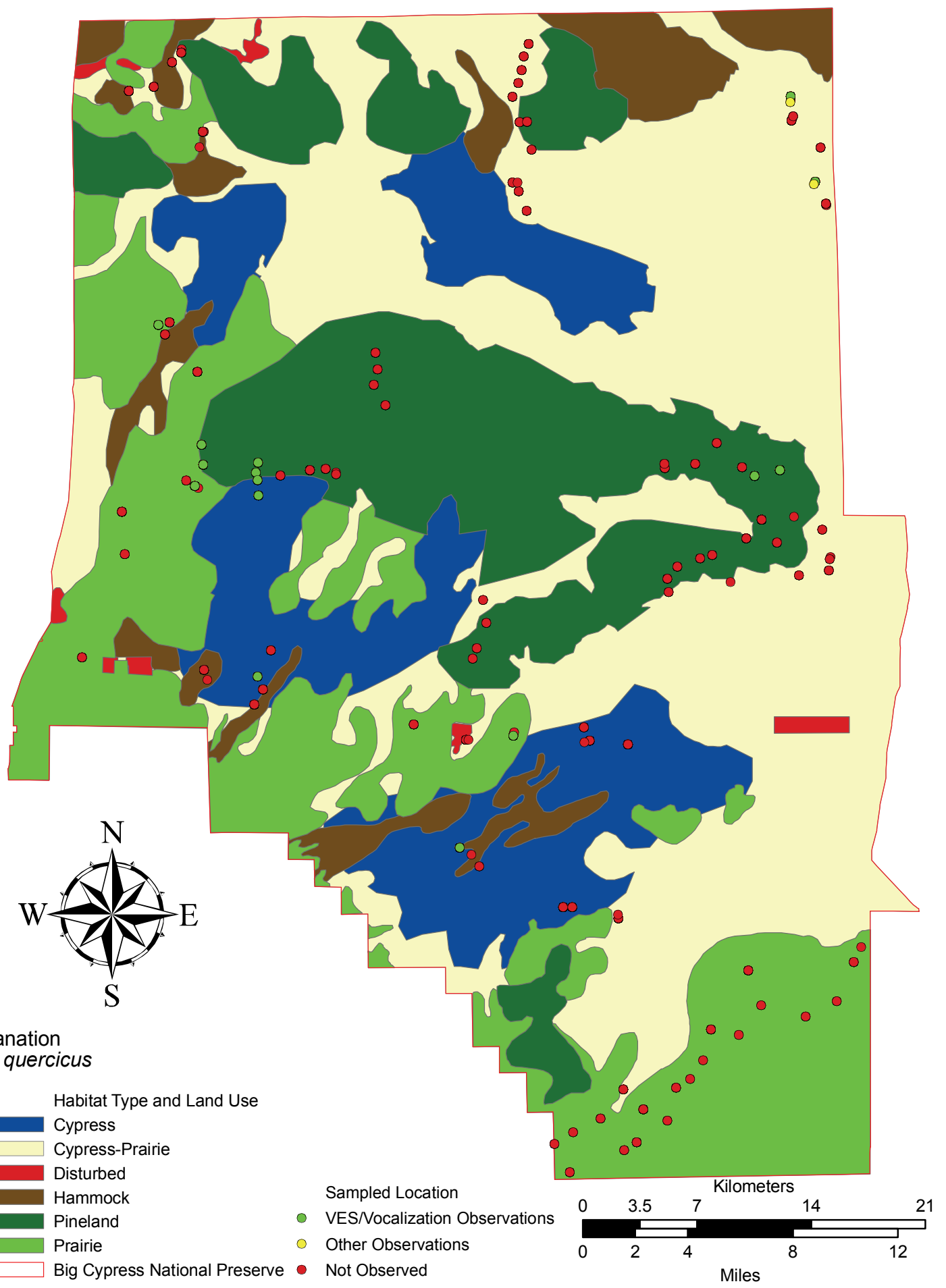

Figure 8. Bufo quercicus locations. Map of all locations at which Bufo quercicus were observed in Big Cypress National Preserve. 


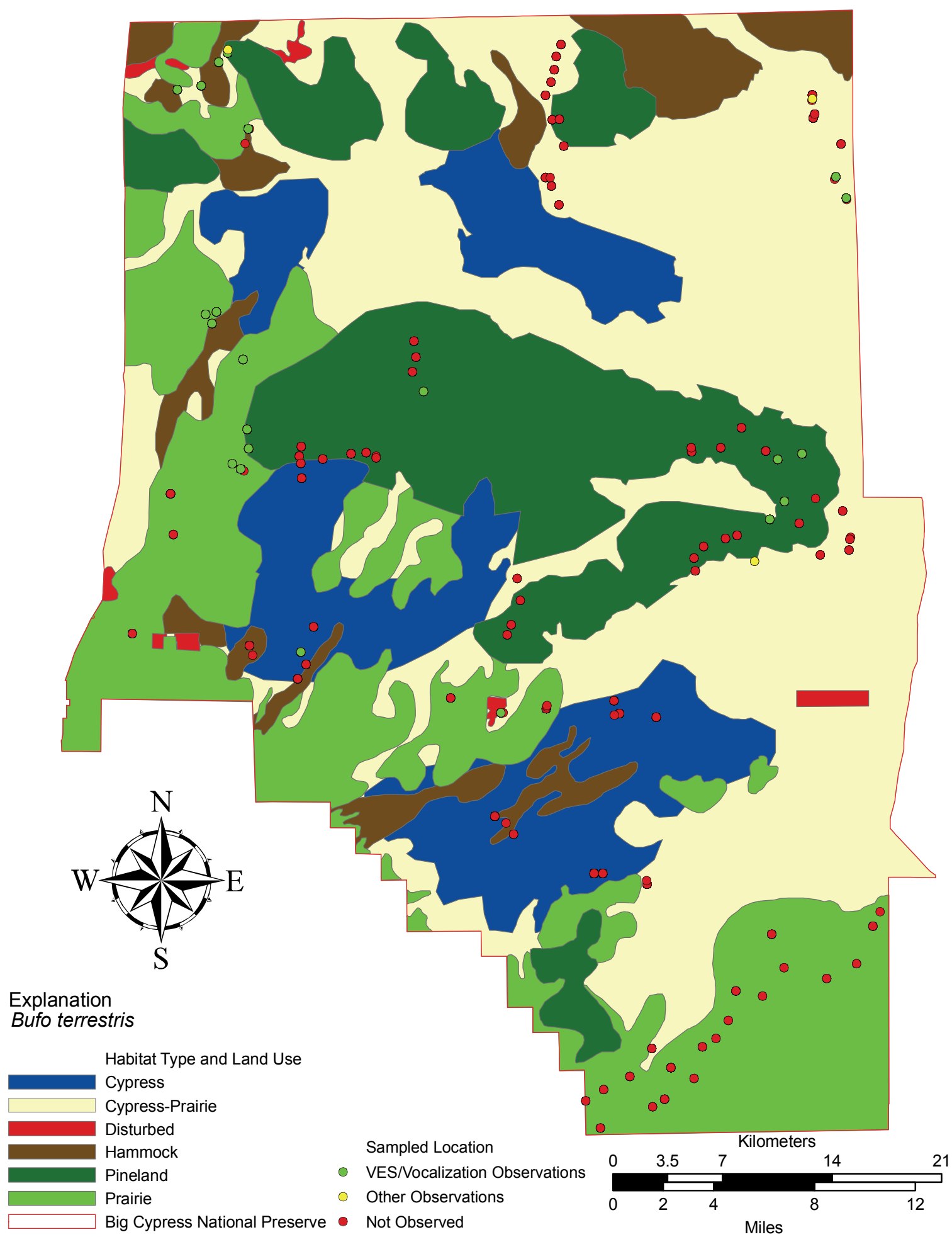

Figure 9. Bufo terrestris locations. Map of all locations at which Bufo terrestris were observed in Big Cypress National Preserve. 


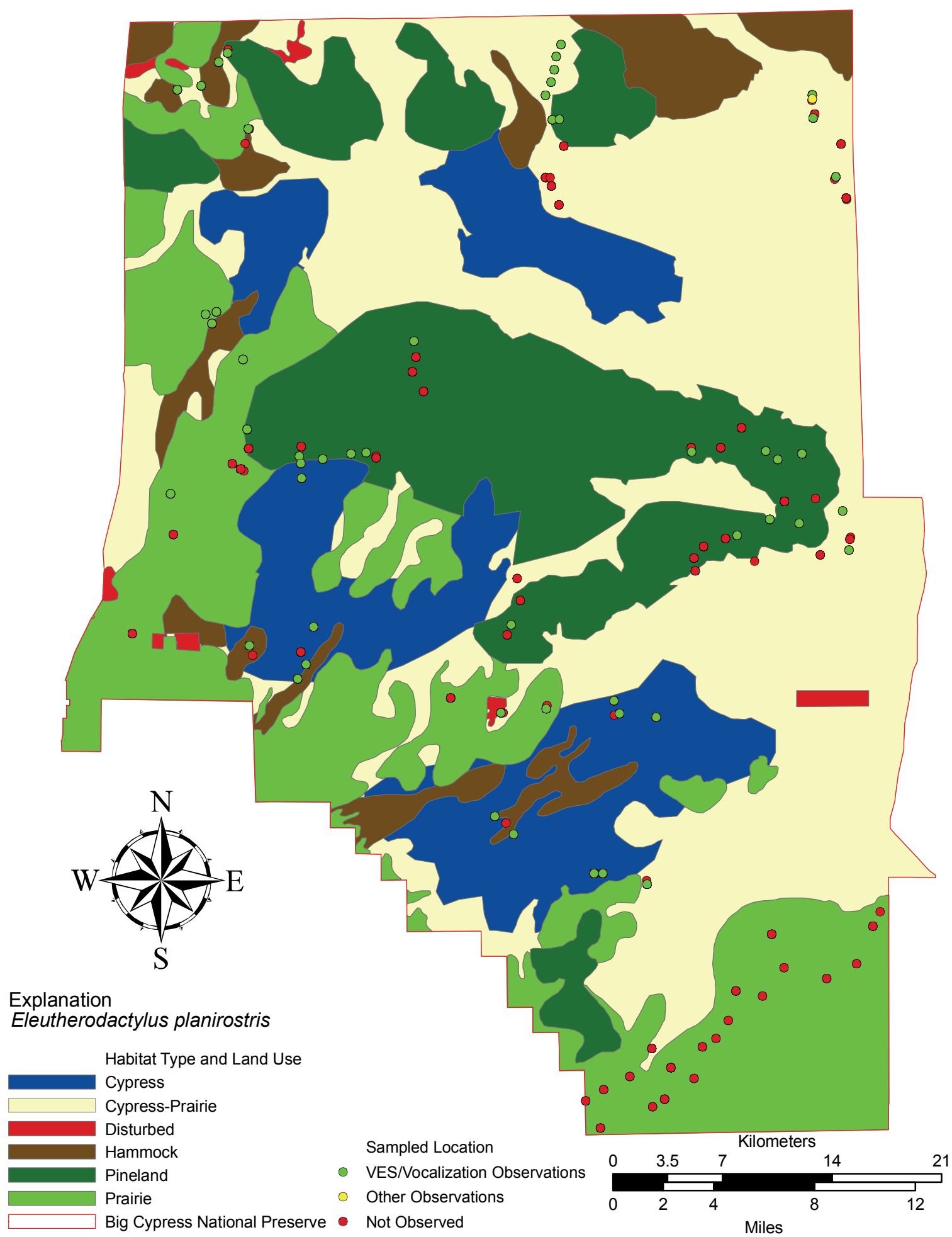

Figure 10. Eleutherodactylus planirostris locations. Map of all locations at which Eleutherodacty/us planirostris were observed in Big Cypress National Preserve. 


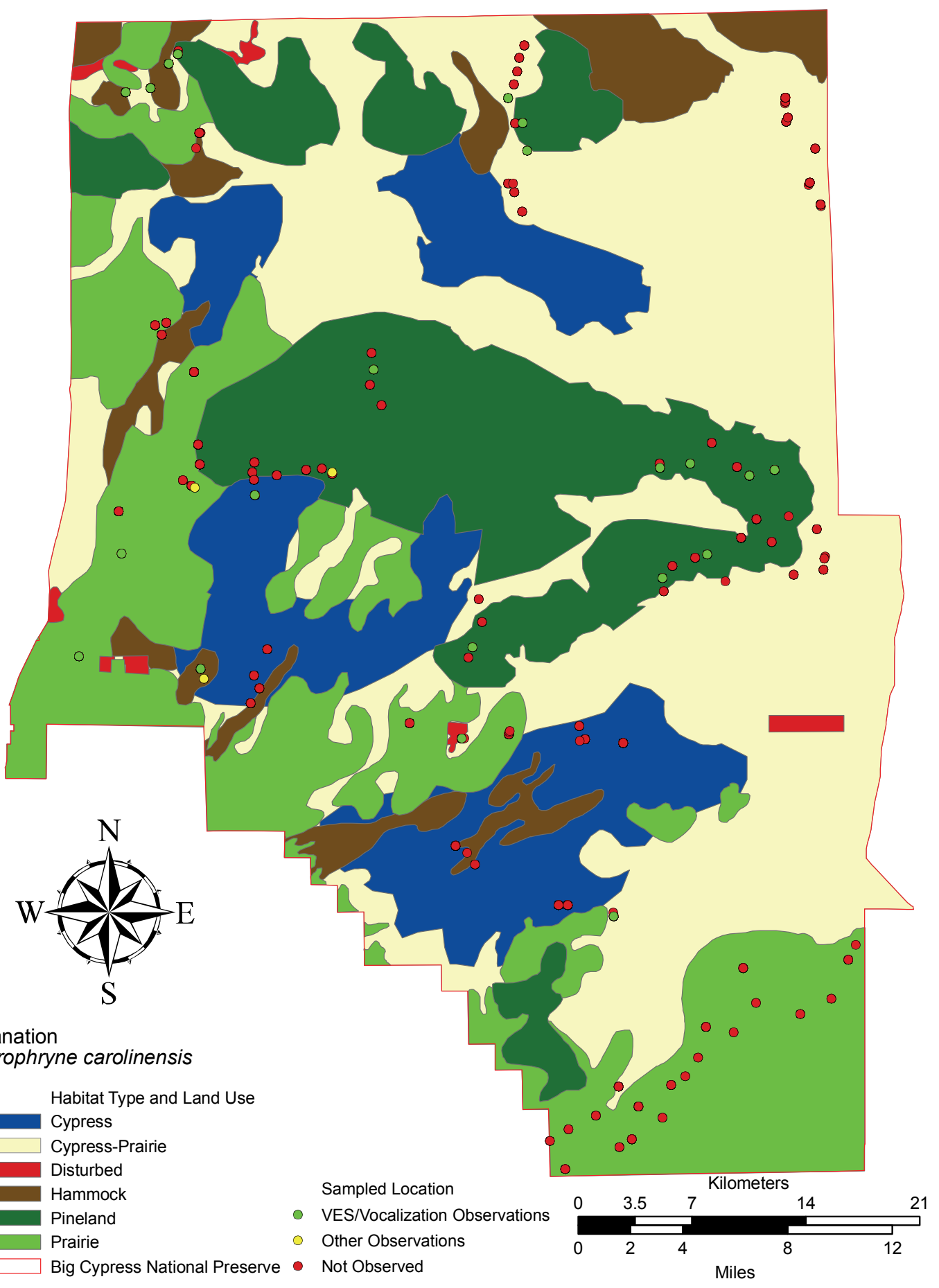

Figure 11. Gastrophryne carolinensis locations. Map of all locations at which Gastrophryne carolinensis were observed in Big Cypress National Preserve. 


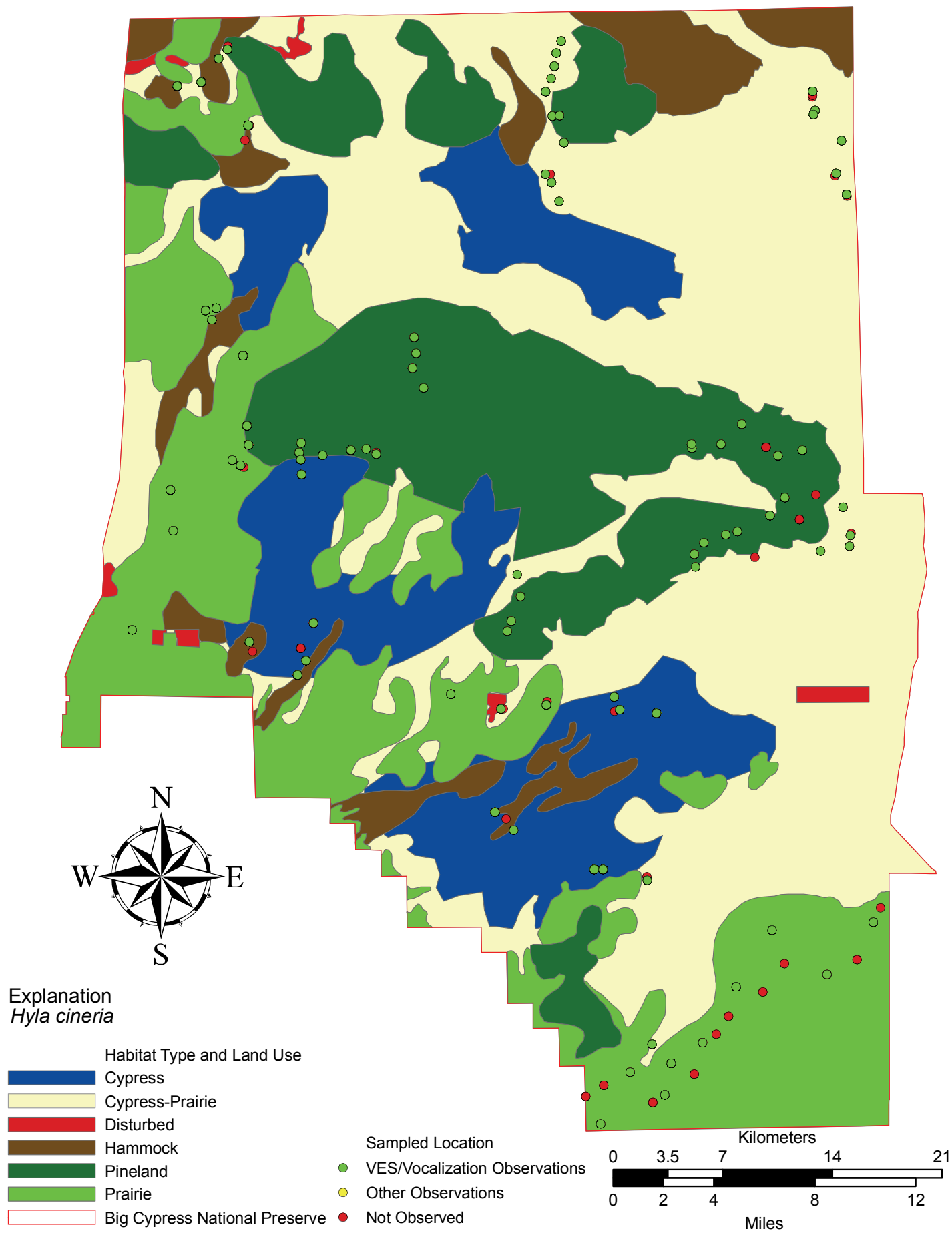

Figure 12. Hyla cinerea locations. Map of all locations at which Hyla cinerea were observed in Big Cypress National Preserve. 


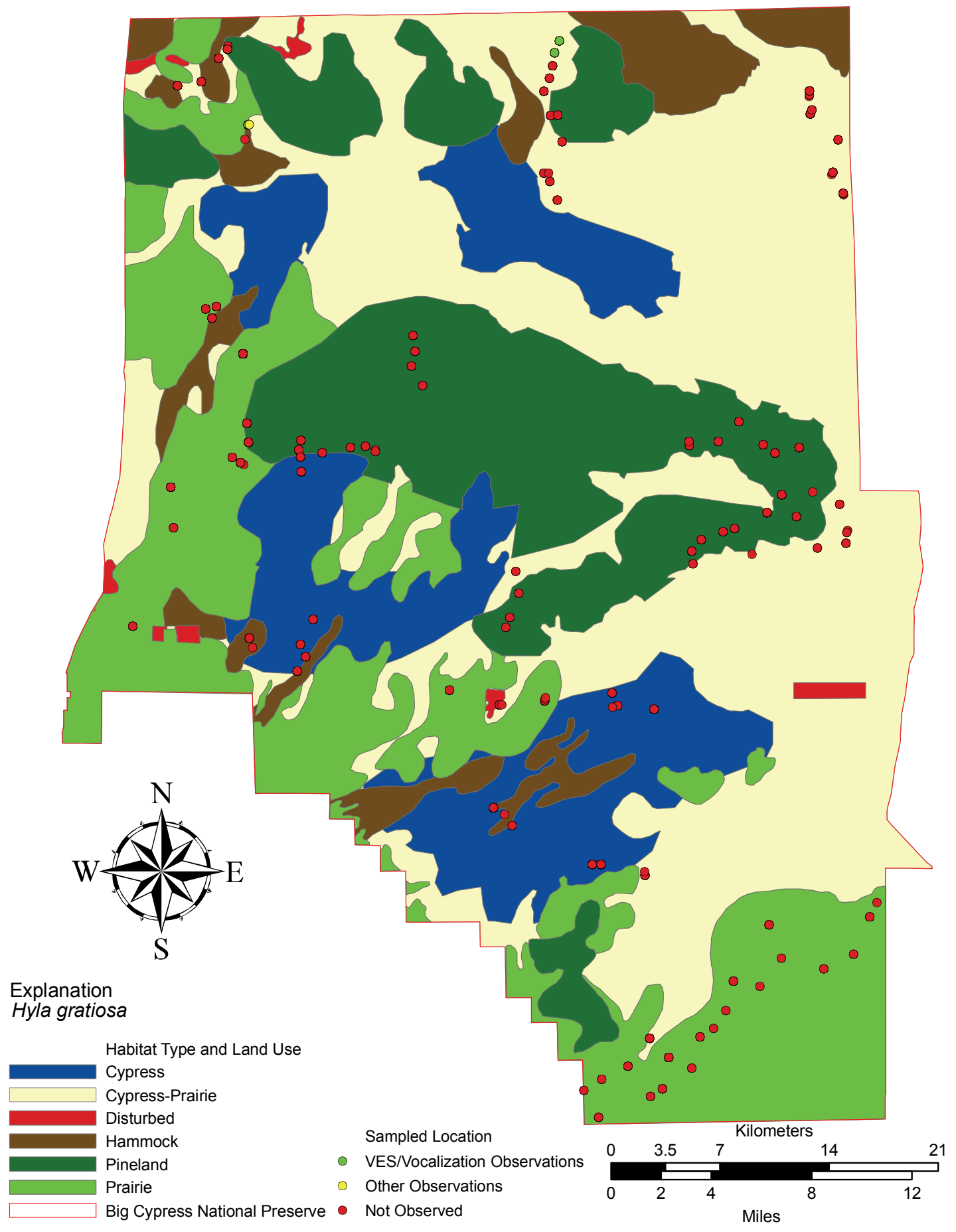

Figure 13. Hyla gratiosa locations. Map of all locations at which Hyla gratiosa ere observed in Big Cypress National Preserve. 


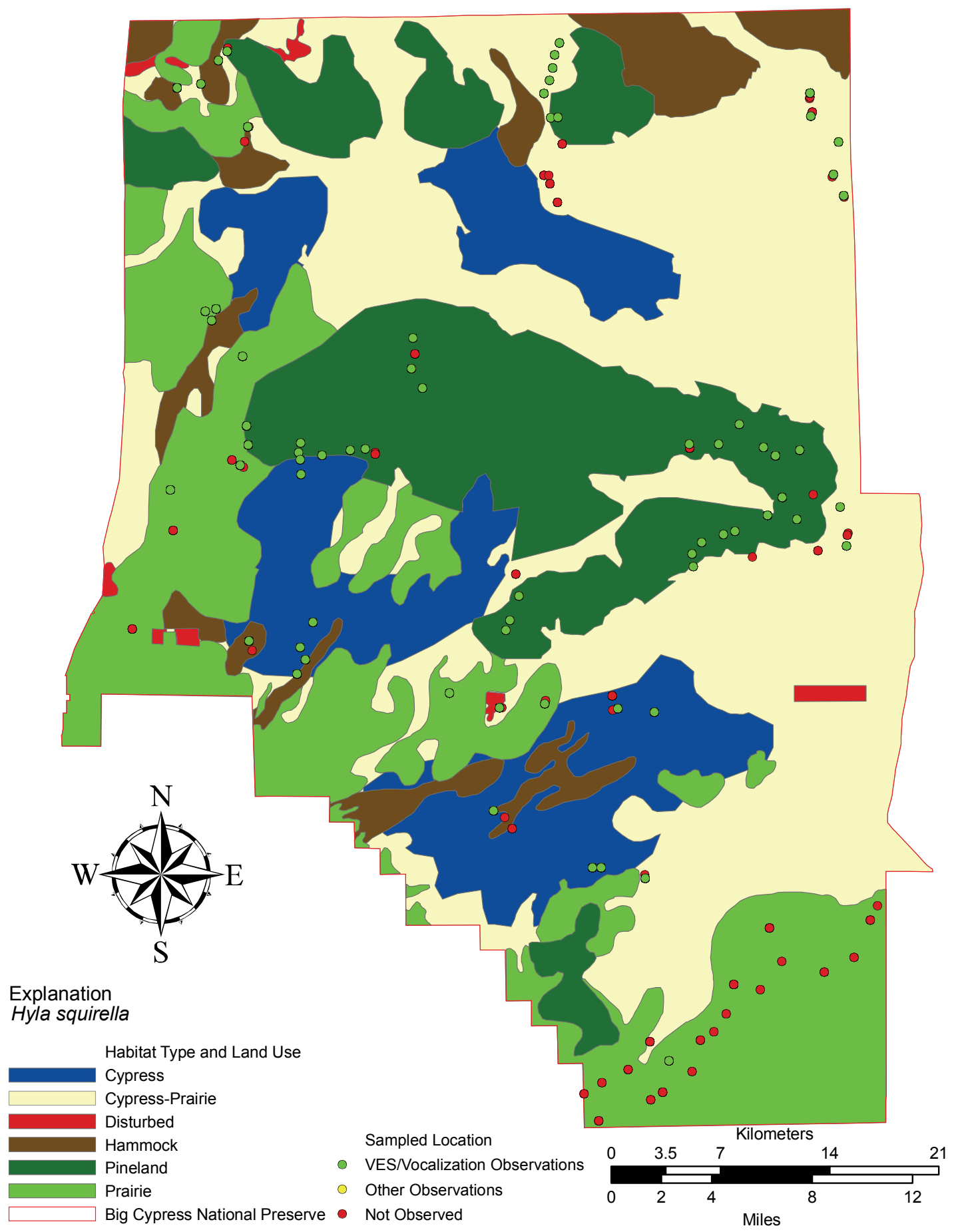

Figure 14. Hyla squirella locations. Map of all locations at which Hyla squirella were observed in Big Cypress National Preserve. 


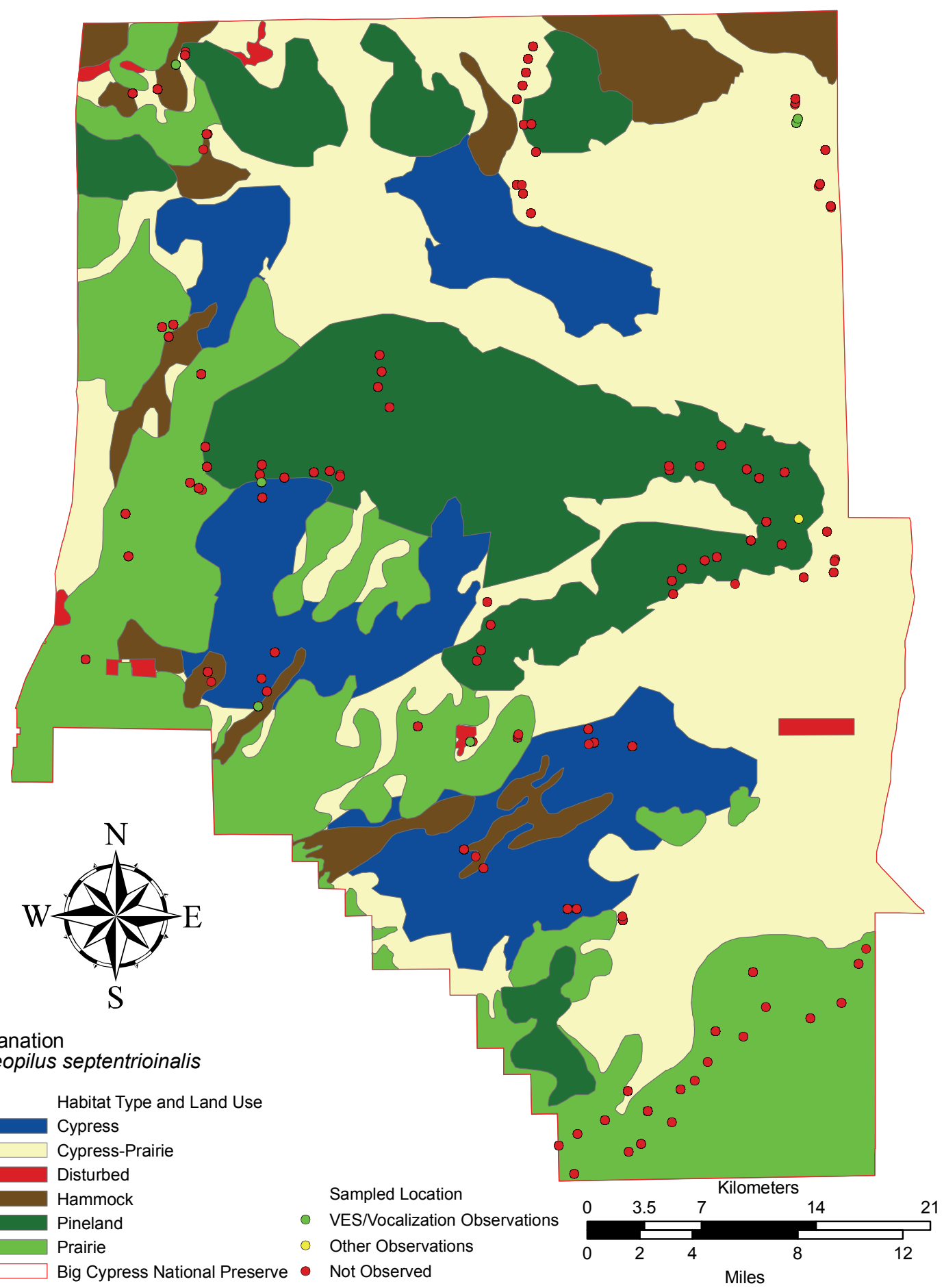

Figure 15. Osteopilus septentrionalis locations. Map of all locations at which Osteopilus septentrionalis were observed in Big Cypress National Preserve. 


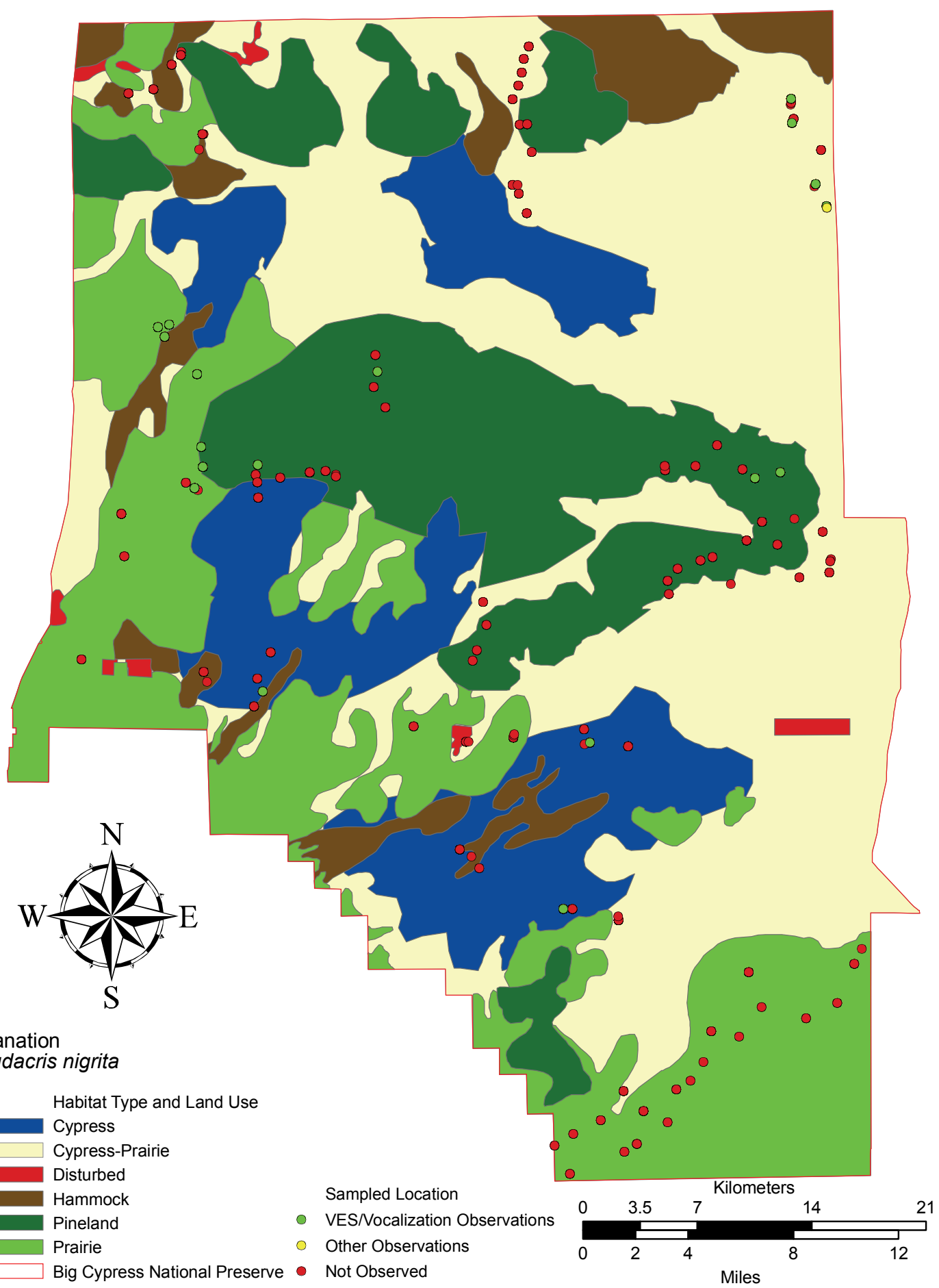

Figure 16. Pseudacris nigrita locations. Map of all locations at which Pseudacris nigrita were observed in Big Cypress National Preserve. 


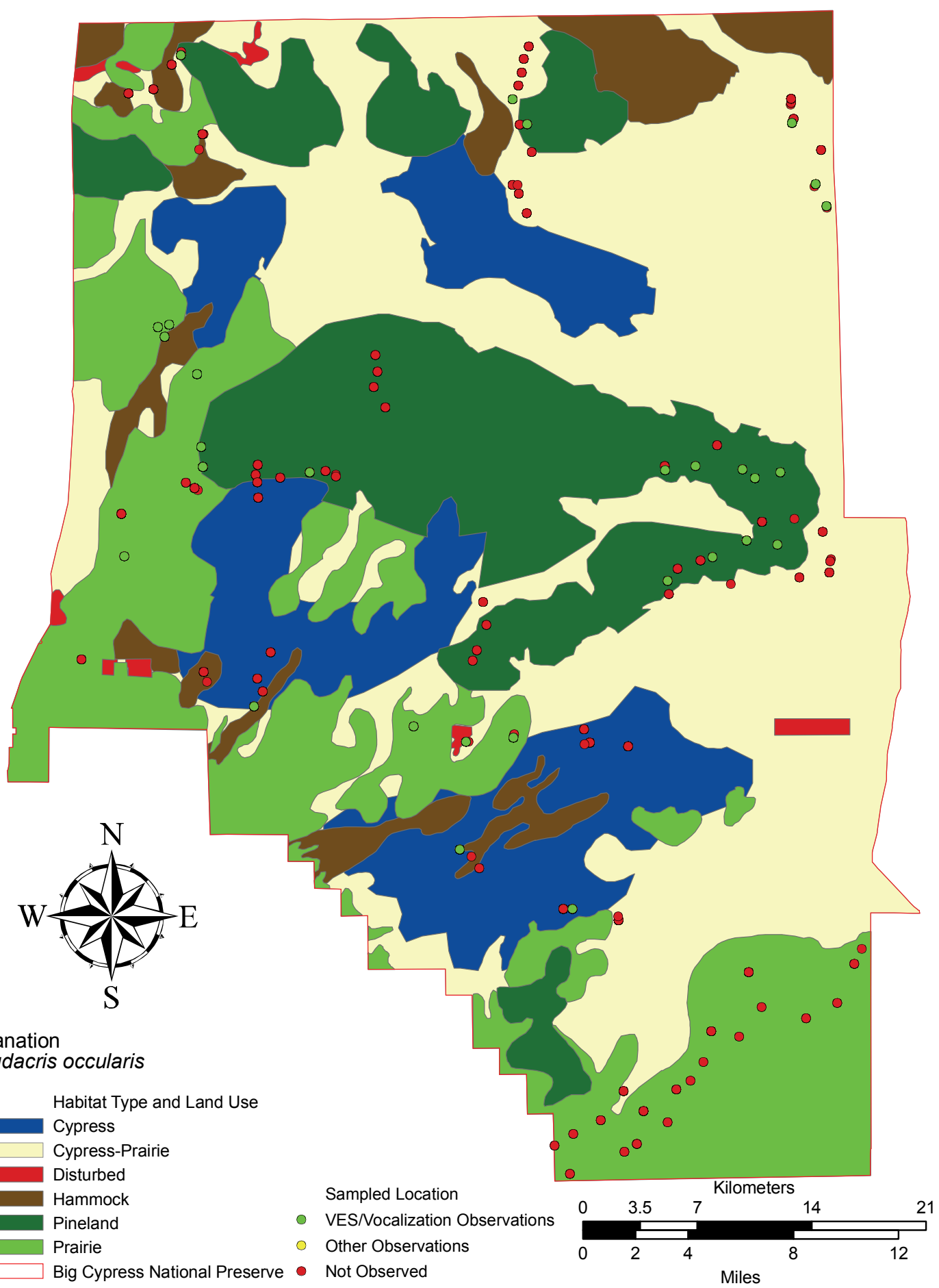

Figure 17. Pseudacris ocularis locations. Map of all locations at which Pseudacris ocularis were observed in Big Cypress National Preserve. 


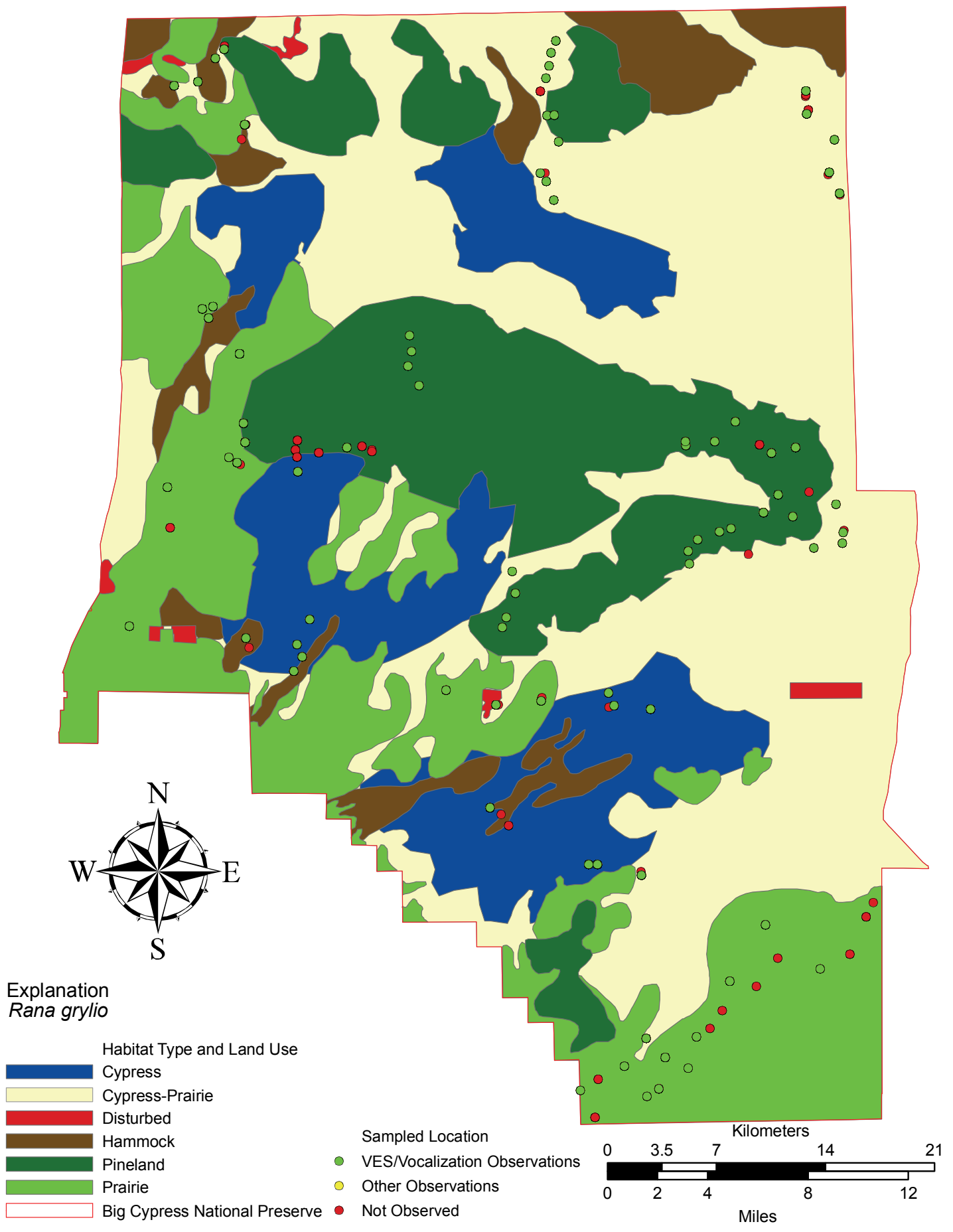

Figure 18. Rana grylio locations. Map of all locations at which Rana grylio were observed in Big Cypress National Preserve. 


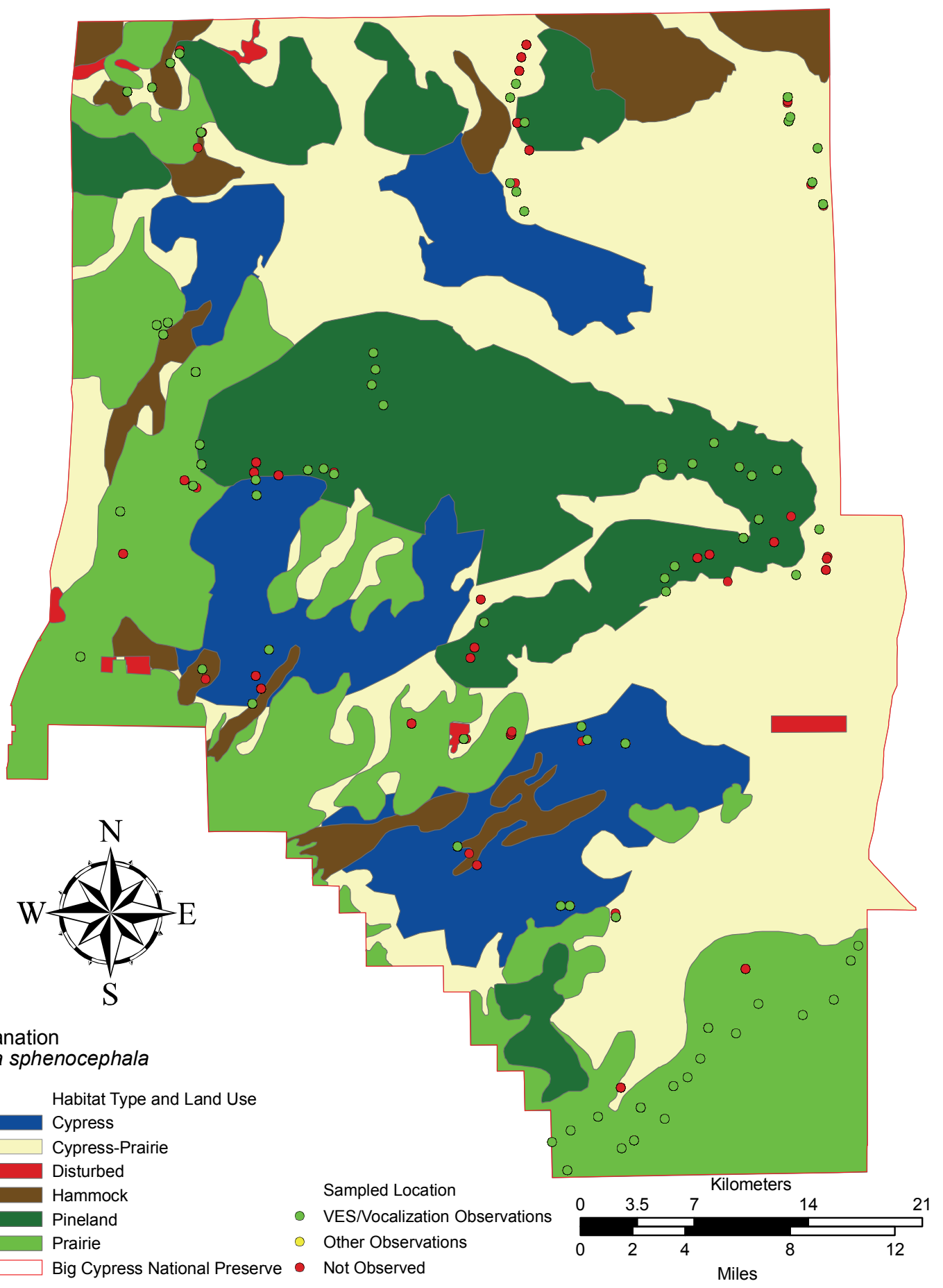

Figure 19. Rana sphenocephala locations. Map of all locations at which Rana sphenocephala were observed in Big Cypress National Preserve. 


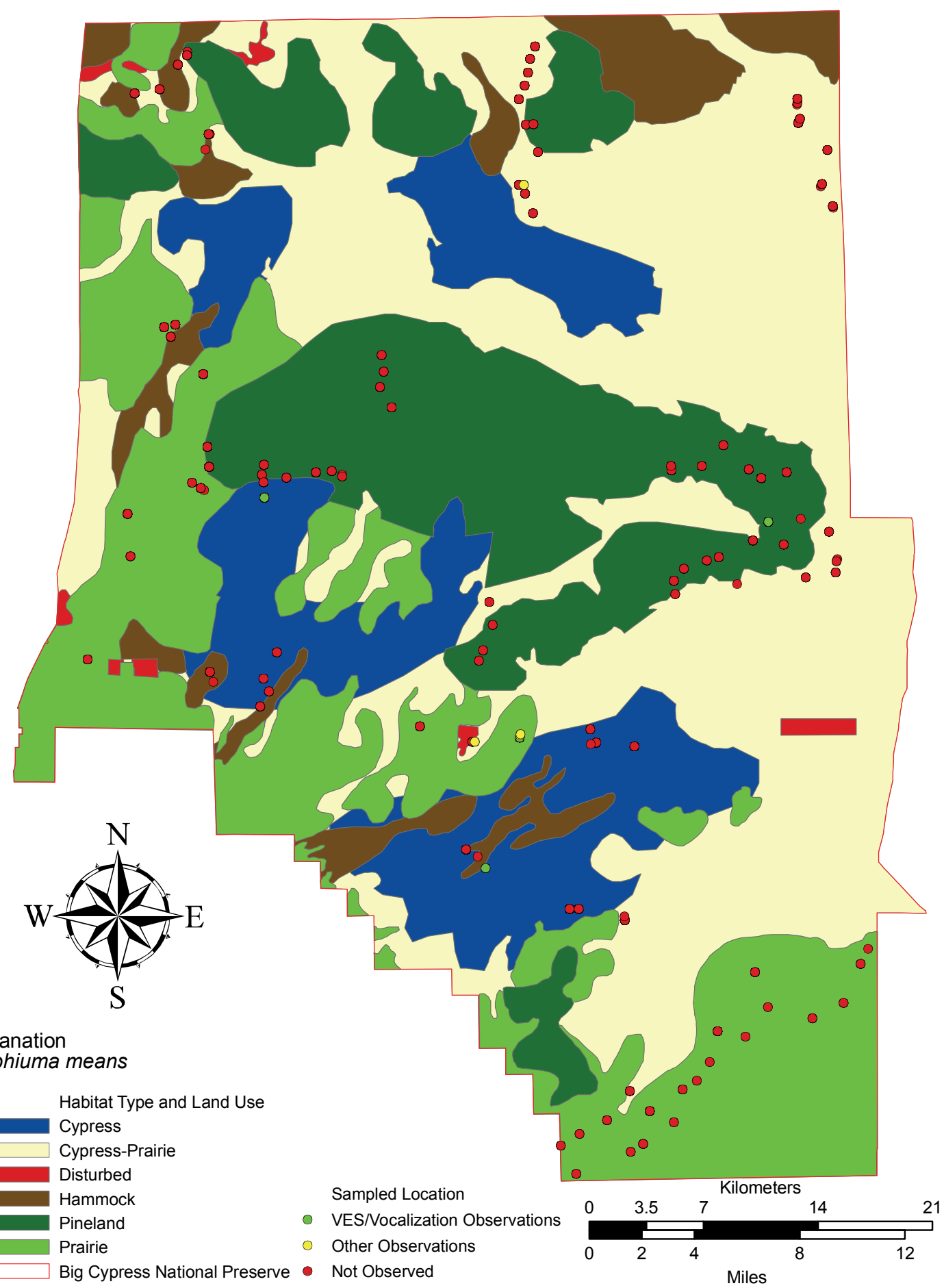

Figure 20. Amphiuma means locations. Map of all locations at which Amphiuma means were observed in Big Cypress National Preserve. 


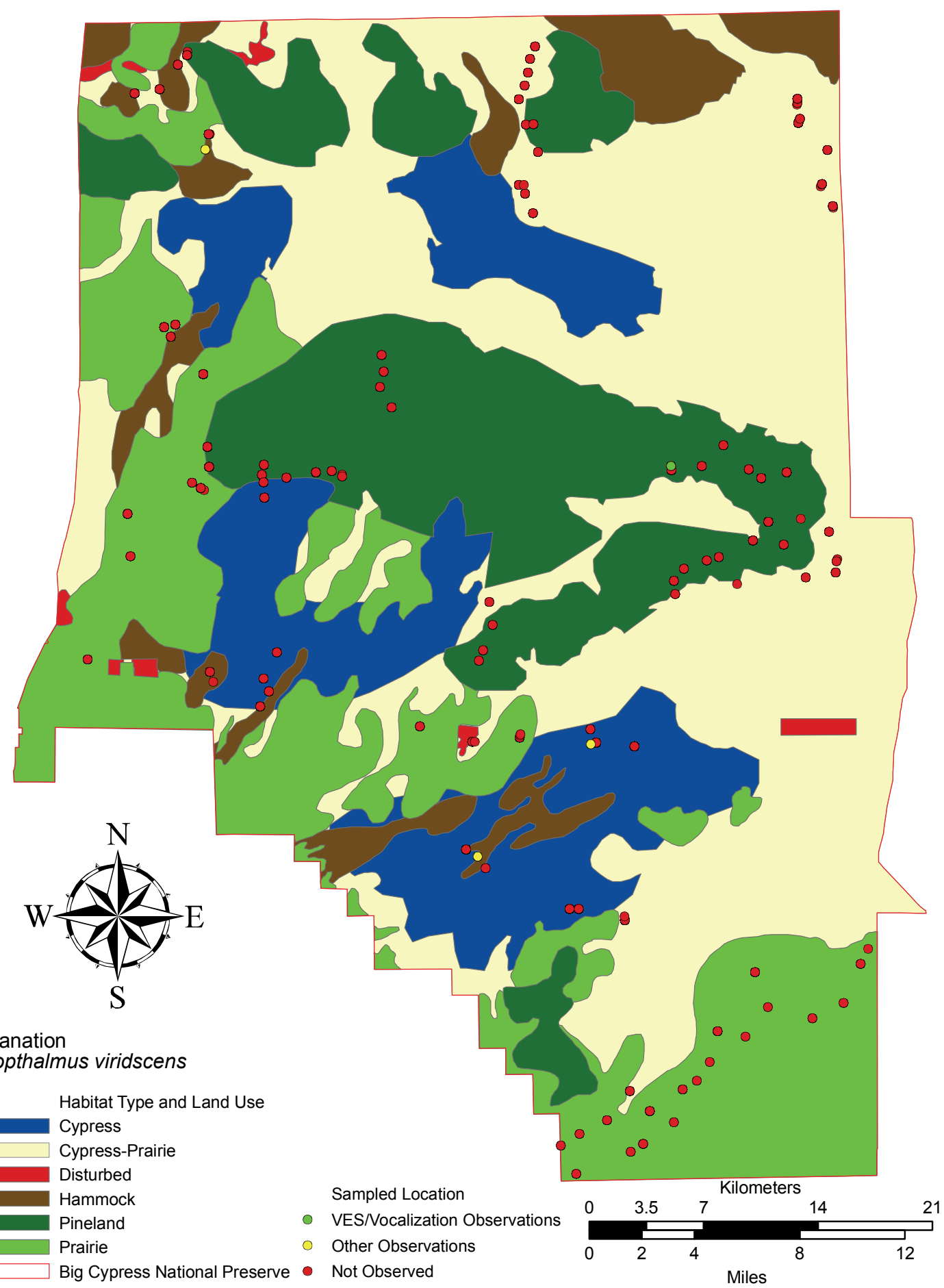

Figure 21. Notophthalmus viridescens locations. Map of all locations at which Notophthalmus viridescens were observed in Big Cypress National Preserve. 


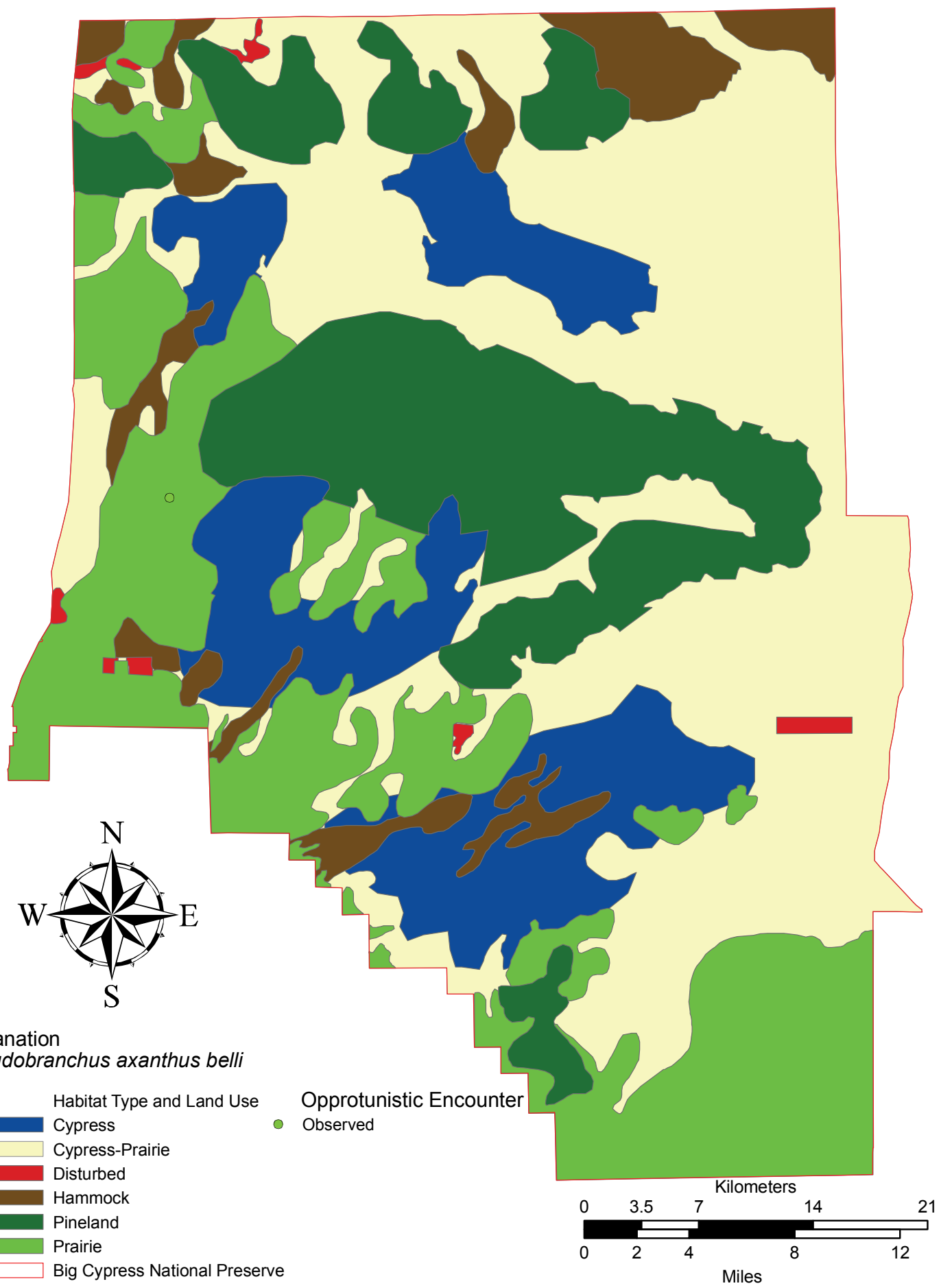

Figure 22. Pseudobranchus axanthus belli locations. Map of all locations at which Pseudobranchus axanthus belli were observed in Big Cypress National Preserve. 


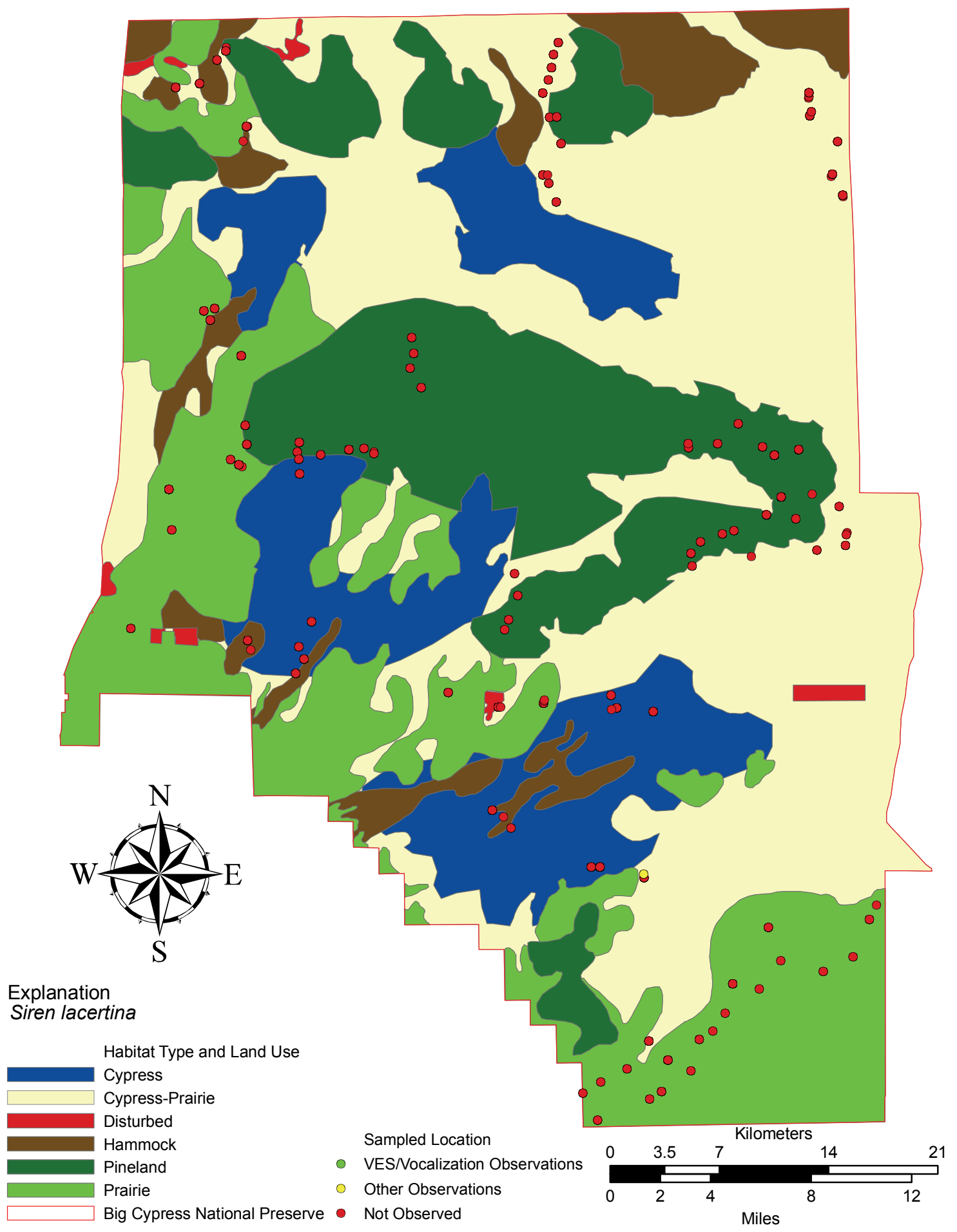

Figure 23. Siren lacertina locations. Map of all locations at which Siren lacertina were observed in Big Cypress National Preserve 


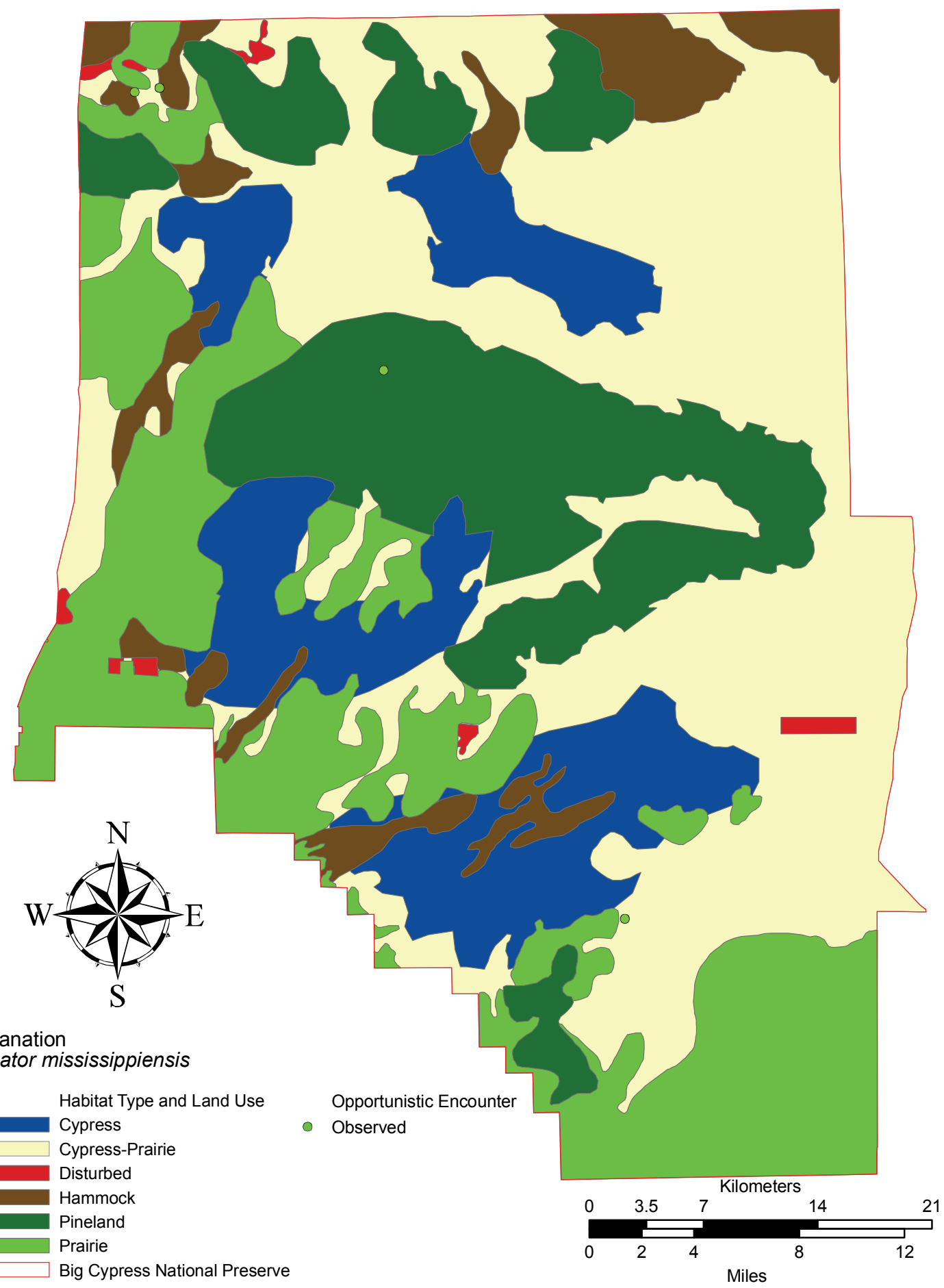

Figure 24. Alligator mississippiensis locations. Map of all locations at which Alligator mississippiensis were observed in Big Cypress National Preserve. 


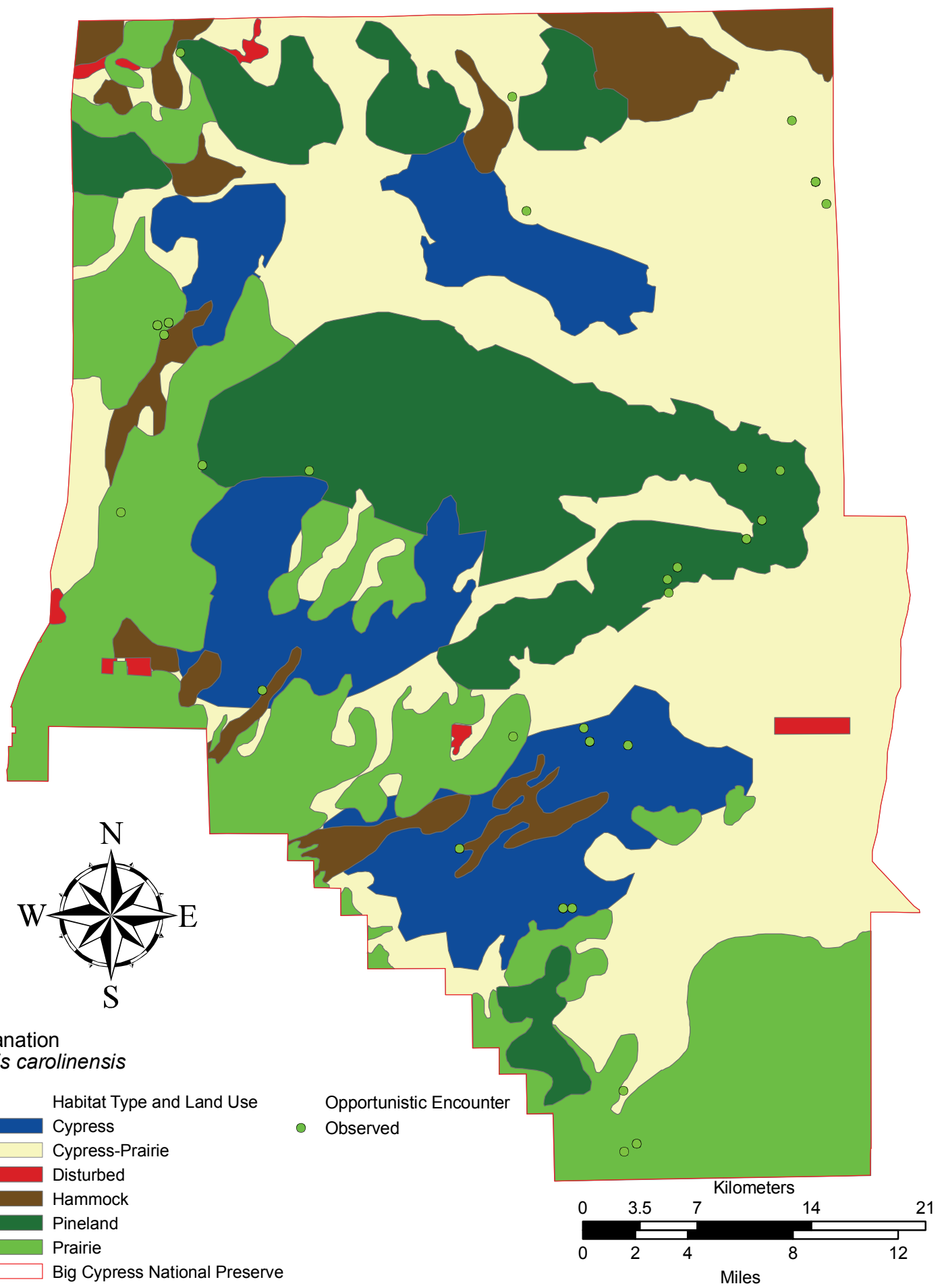

Figure 25. Anolis carolinensis locations. Map of all locations at which Anolis carolinensis were observed in Big Cypress National Preserve. 


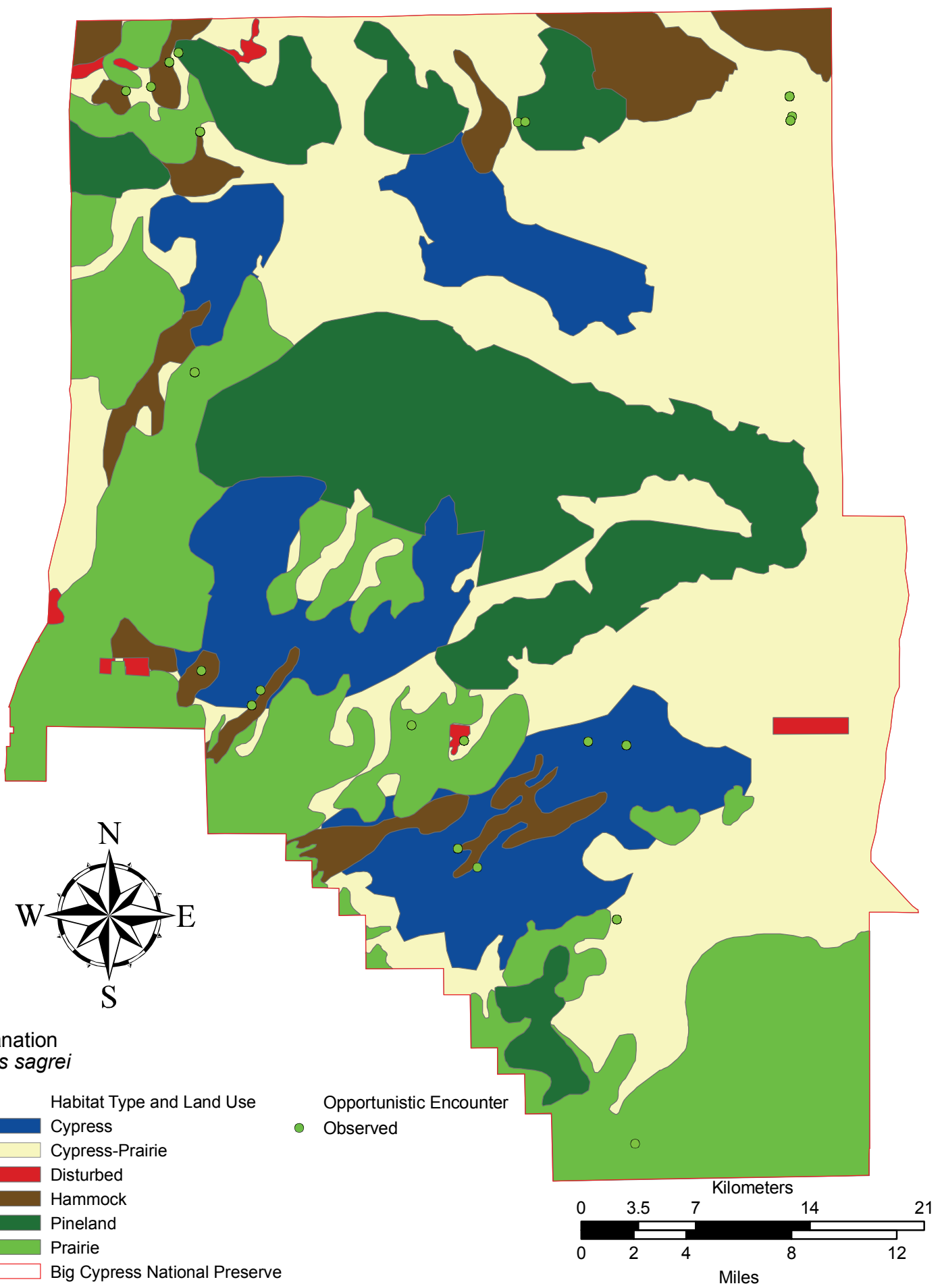

Figure 26. Anolis sagreilocations. Map of all locations at which Anolis sagrei were observed in Big Cypress National Preserve. 


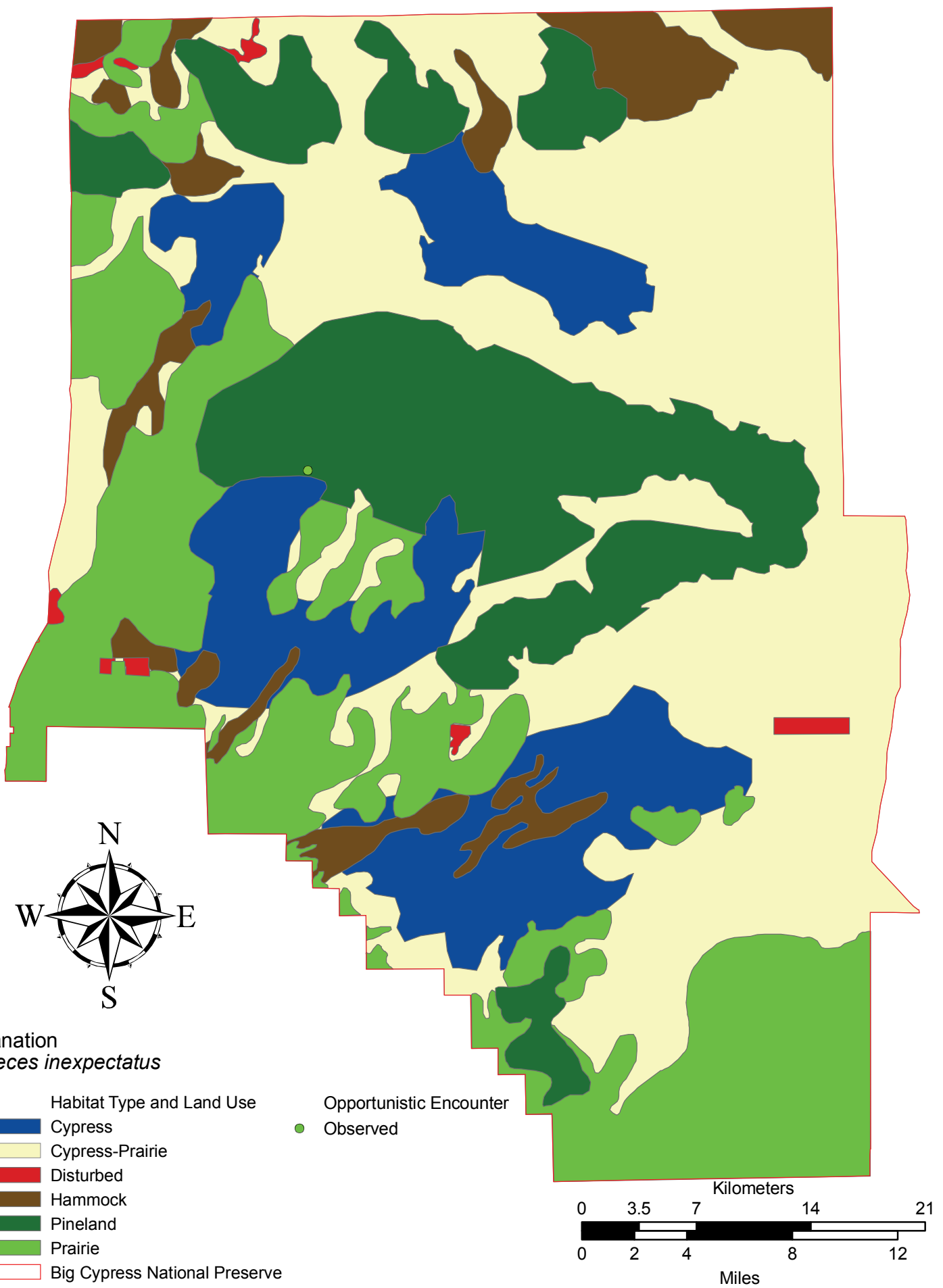

Figure 27. Eumeces inexpectatus locations. Map of all locations at which Eumeces inexpectatus were observed in Big Cypress National Preserve. 


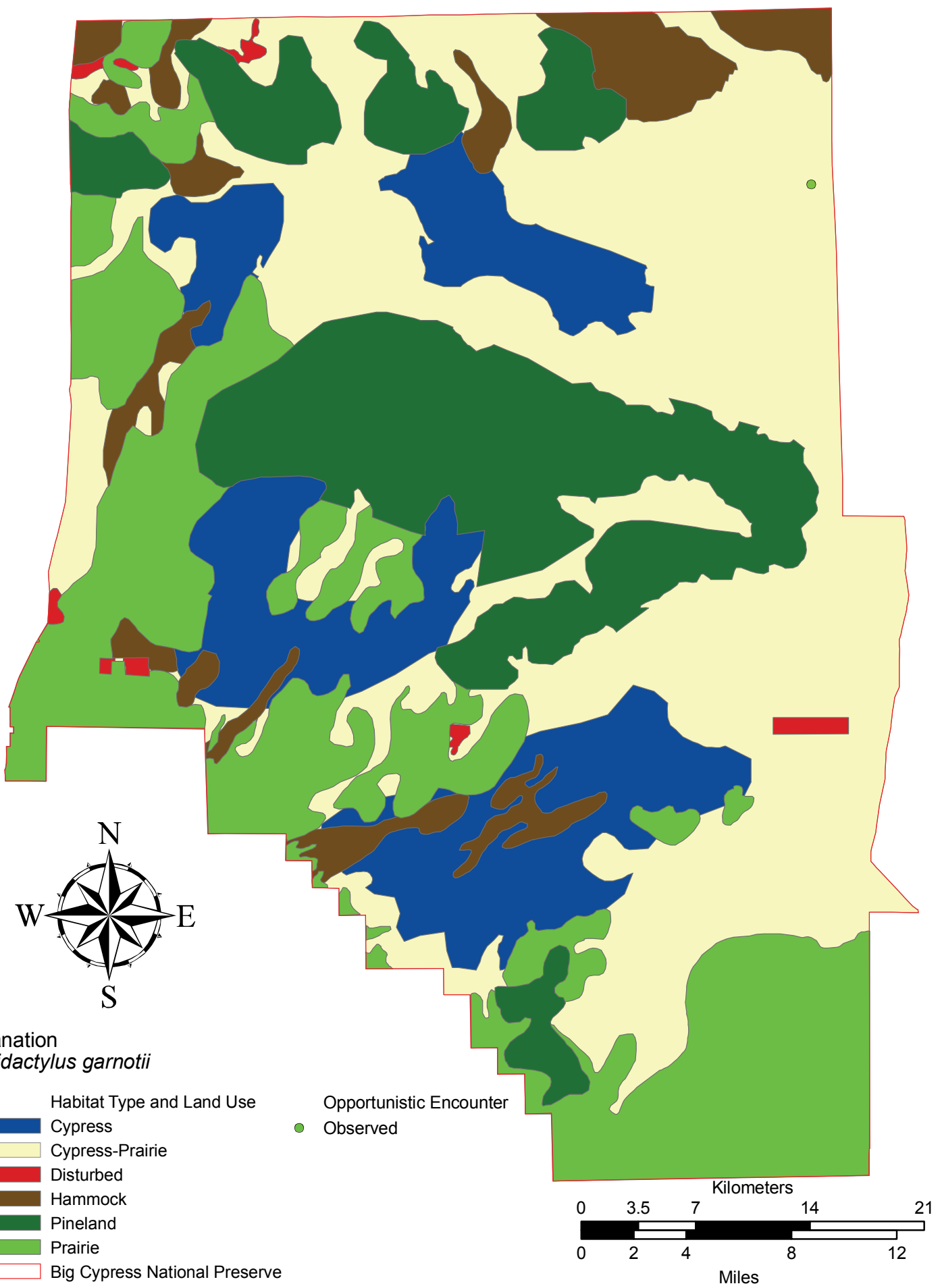

Figure 28. Hemidactylus garnotii locations. Map of all locations at which Hemidacty/us garnotii were observed in Big Cypress National Preserve. 


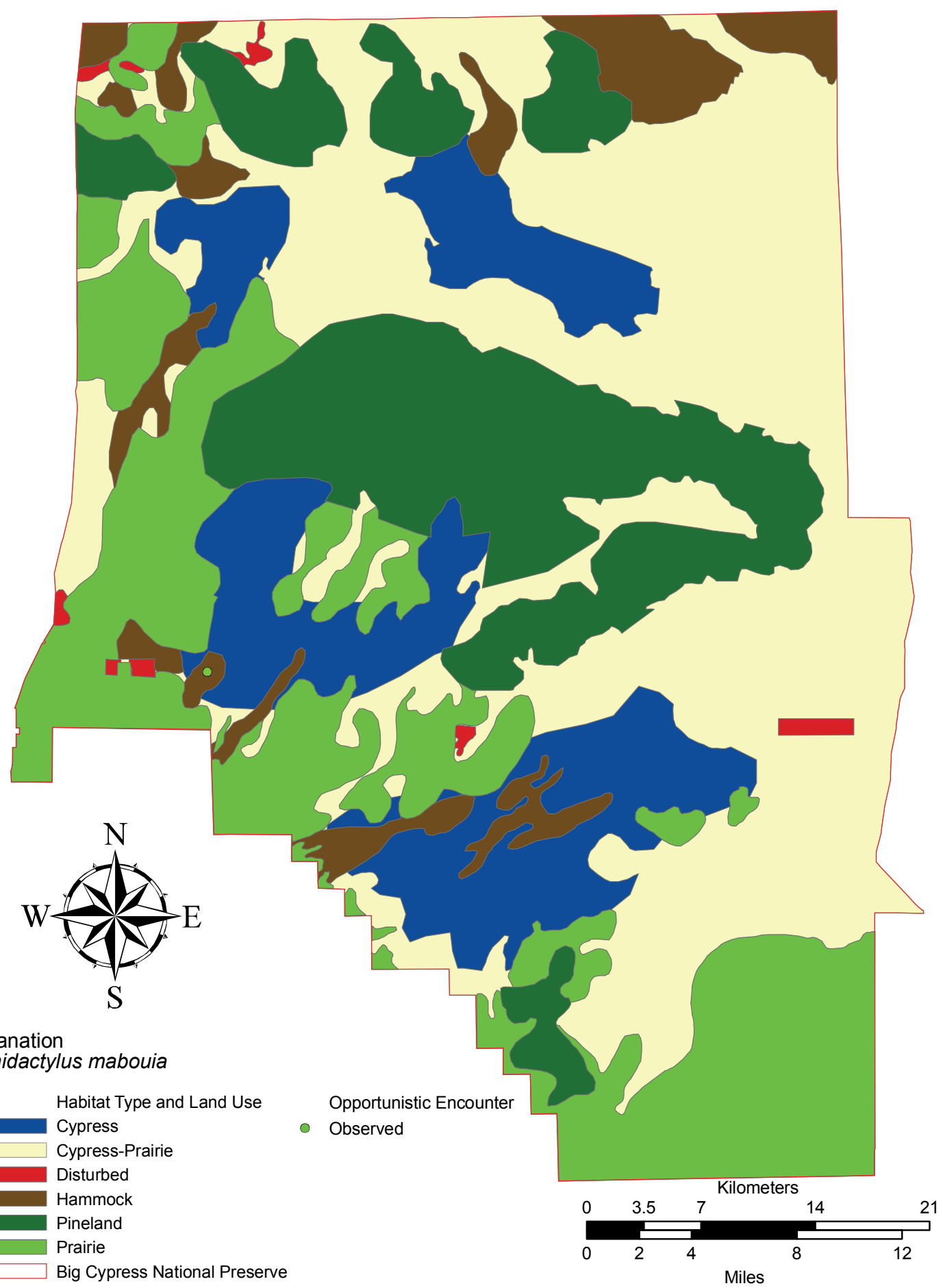

Figure 29. Hemidactylus mabouia locations. Map of all locations at which Hemidacty/us mabouia were observed in Big Cypress National Preserve. 


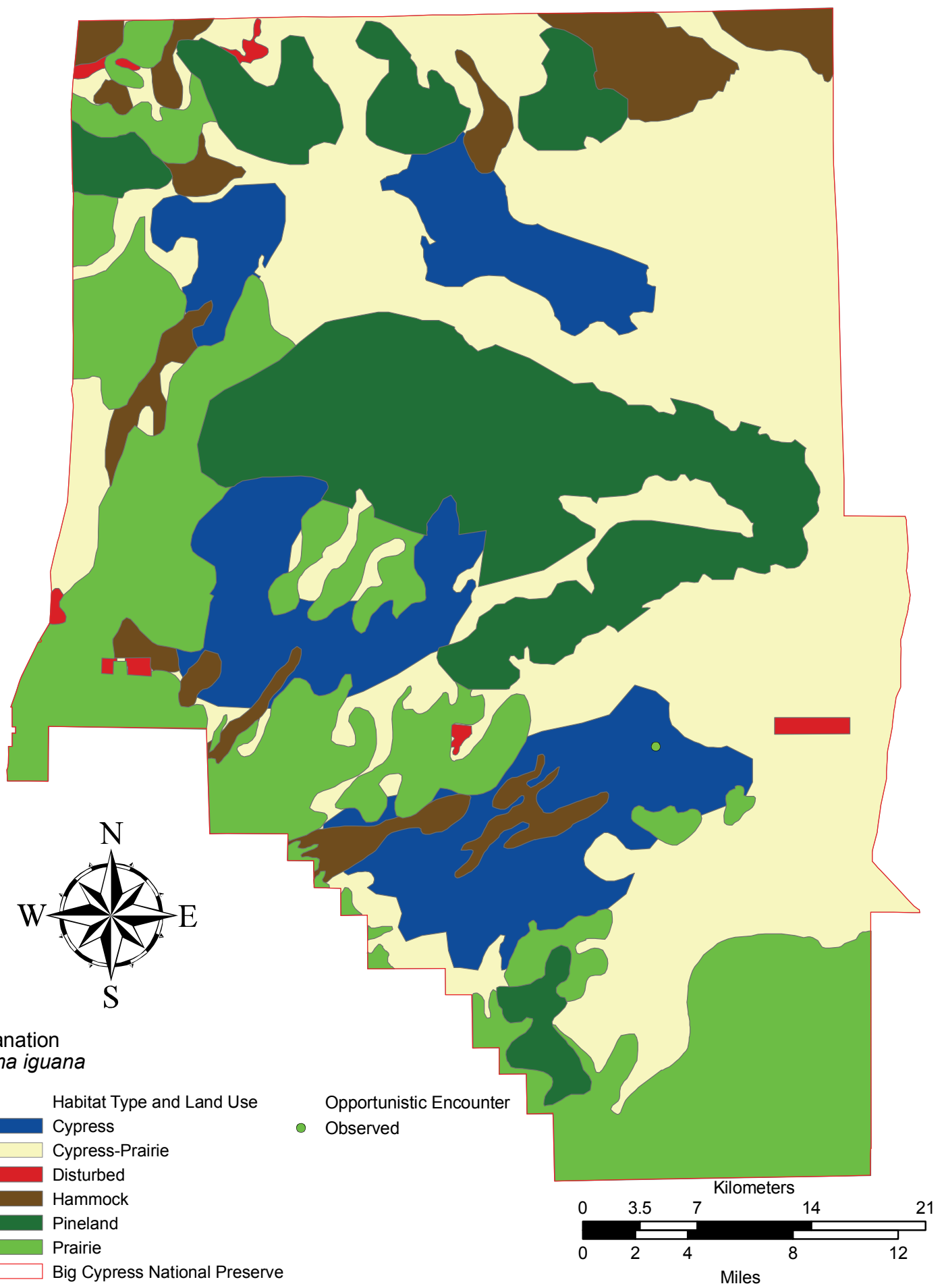

Figure 30. Iguana iguana locations. Map of all locations at which Iguana iguana were observed in Big Cypress National Preserve. 


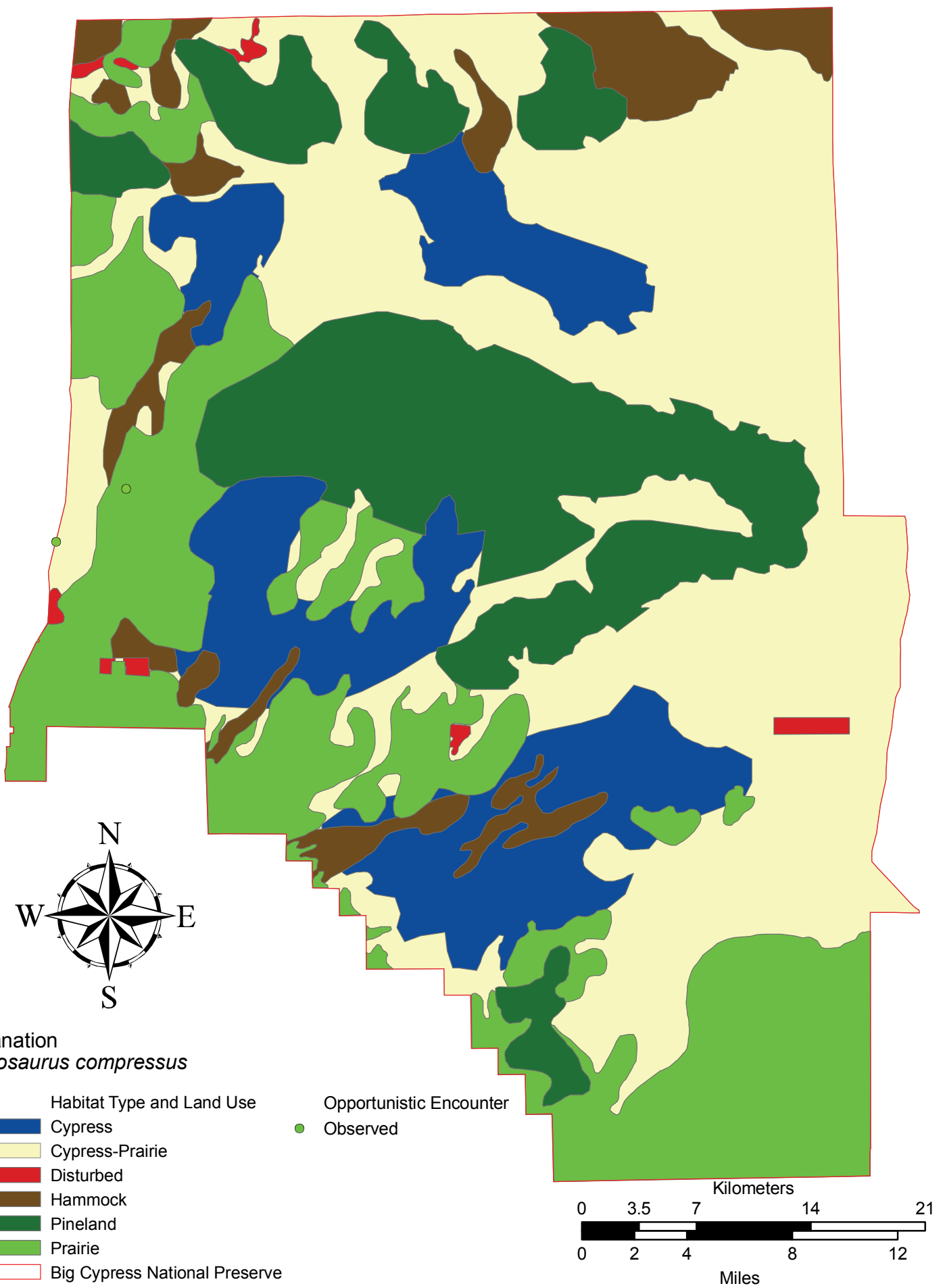

Figure 31. Ophisaurus compressus locations. Map of all locations at which Ophisaurus compressus were observed in Big Cypress National Preserve. 


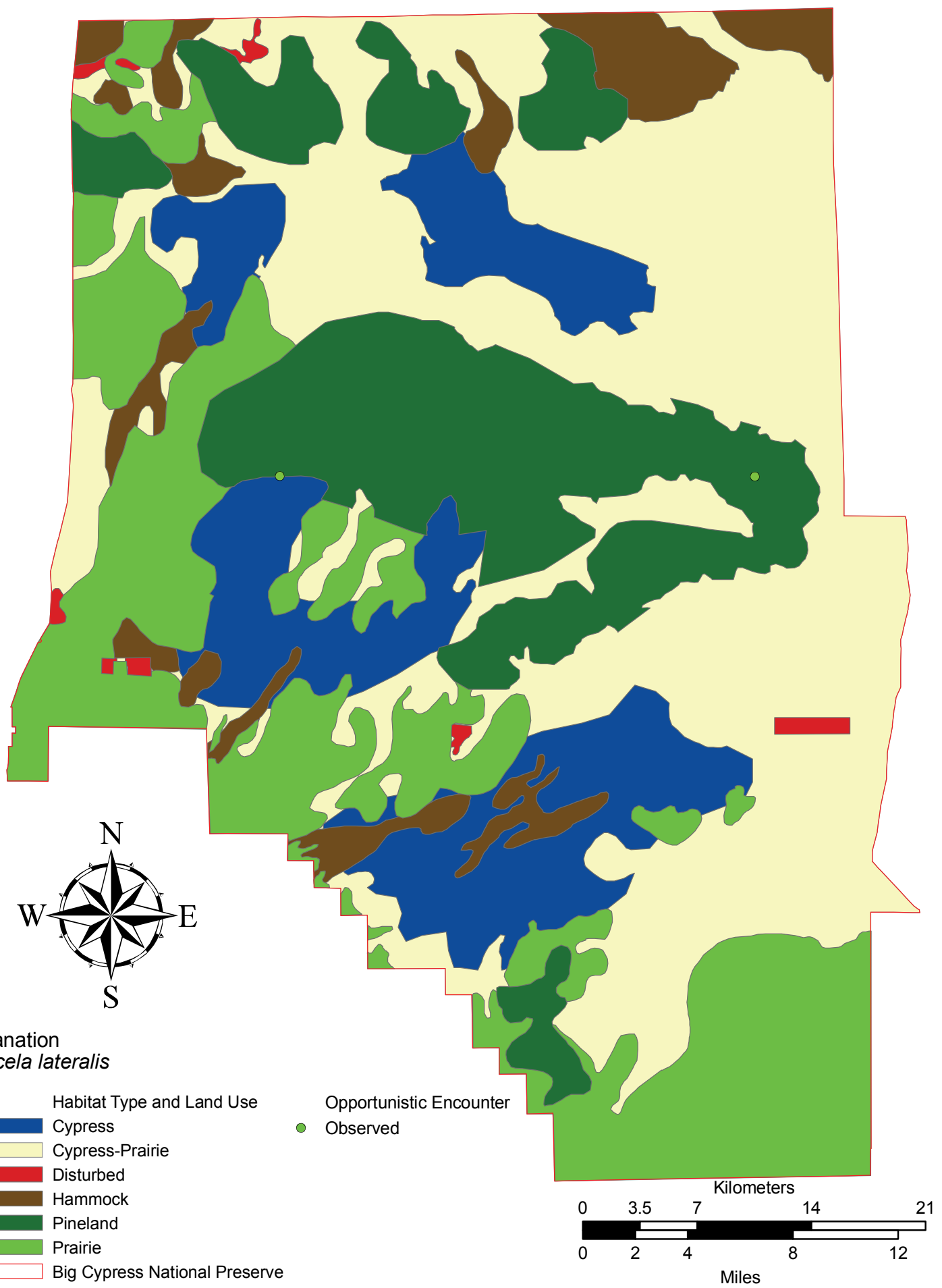

Figure 32. Scincella lateralis locations. Map of all locations at which Scincella lateralis were observed in Big Cypress National Preserve. 


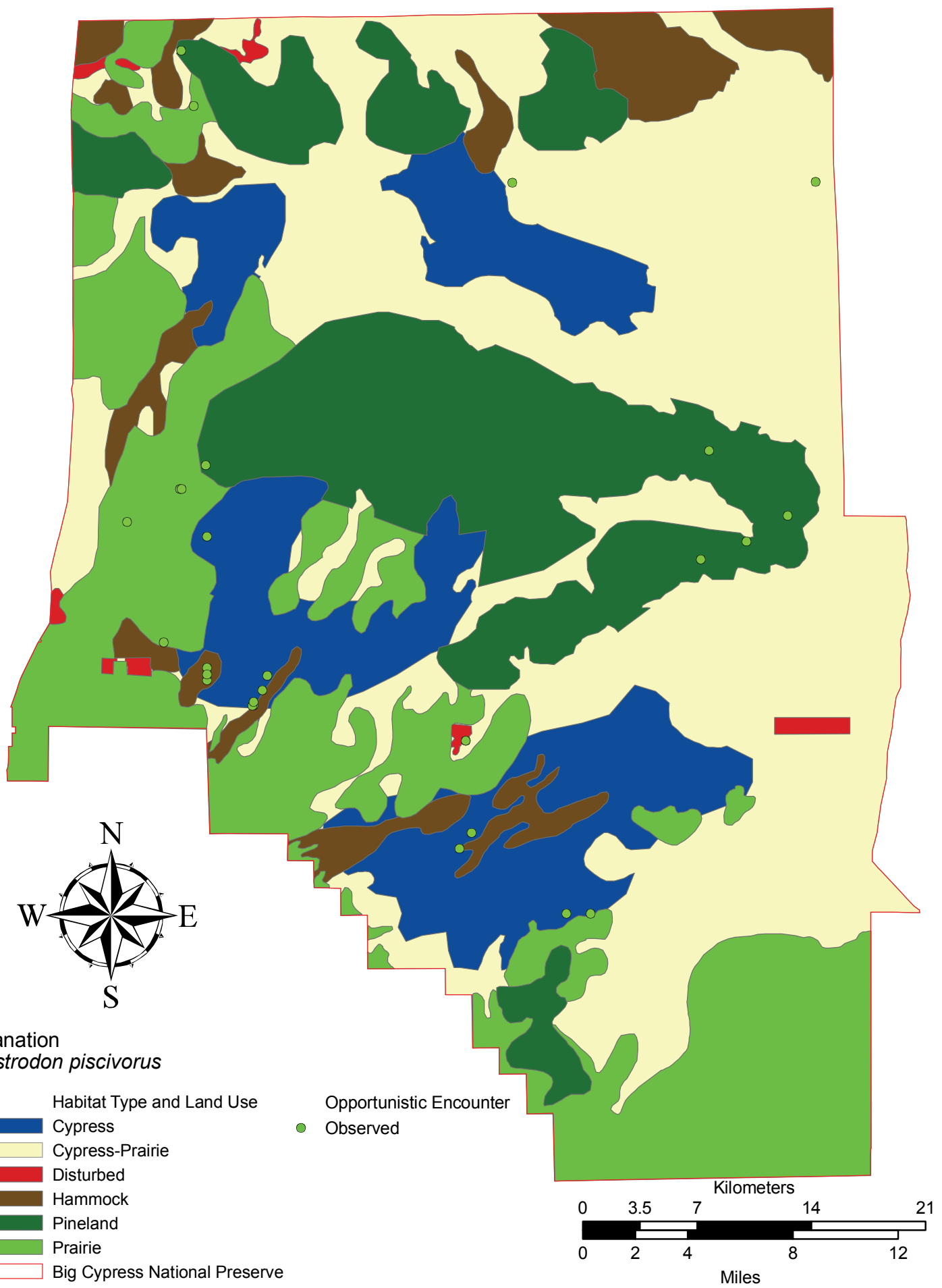

Figure 33. Agkistrodon piscivorus locations. Map of all locations at which Agkistrodon piscivorus were observed in Big Cypress National Preserve. 


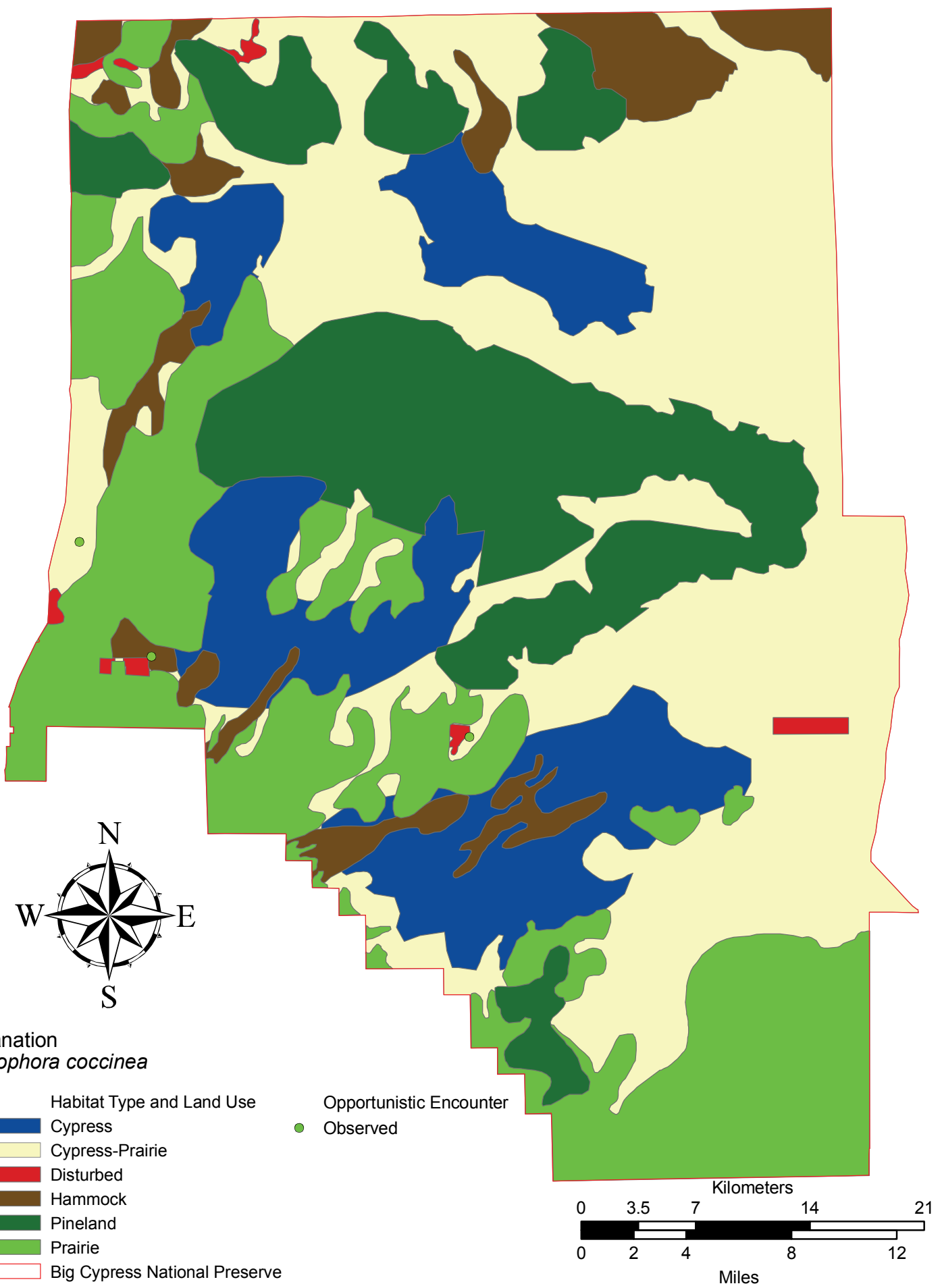

Figure 34. Cemophora coccinea locations. Map of all locations at which Cemophora coccinea were observed in Big Cypress National Preserve. 


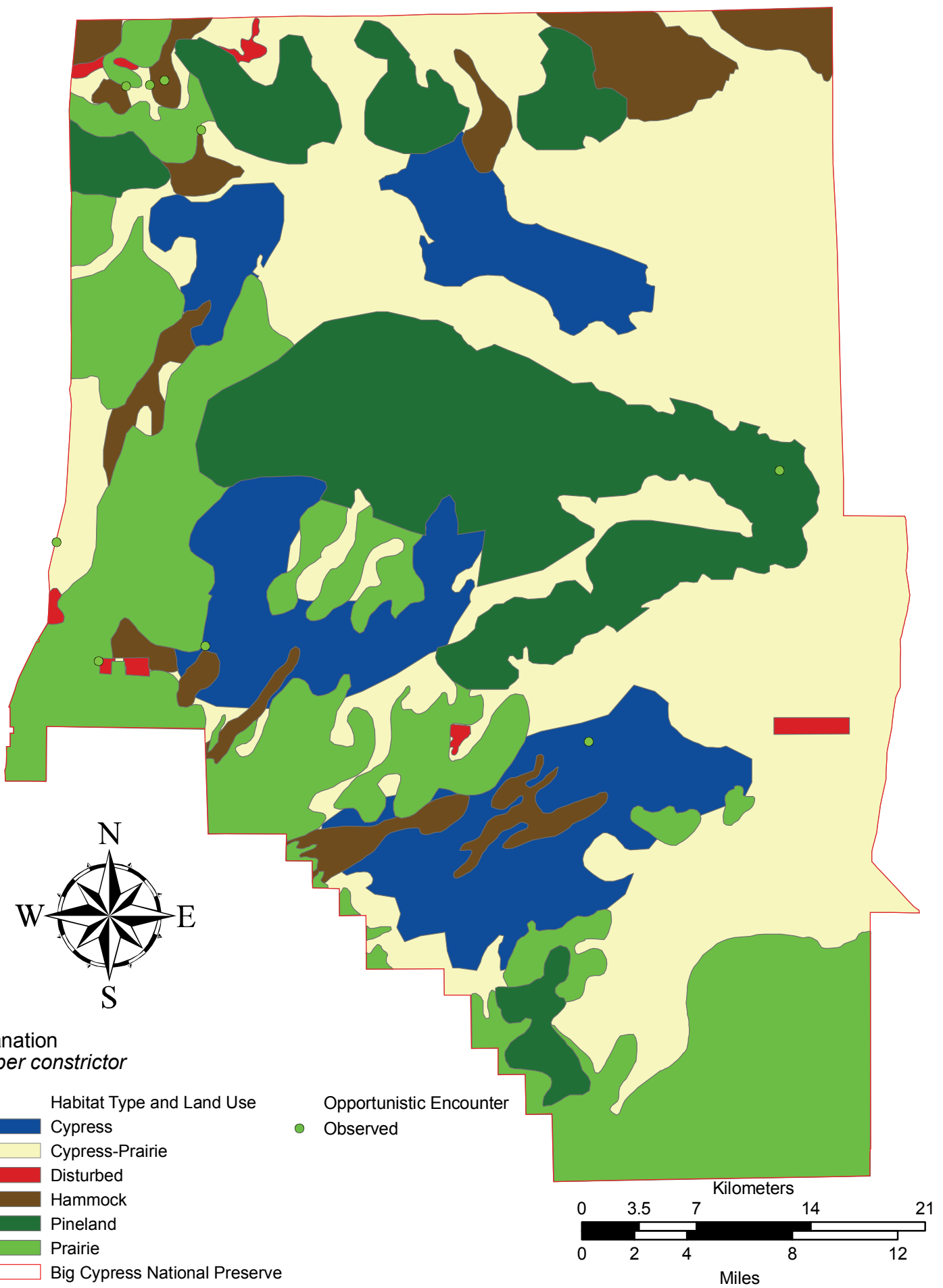

Figure 35. Coluber constrictor locations. Map of all locations at which Coluber constrictor were observed in Big Cypress National Preserve. 


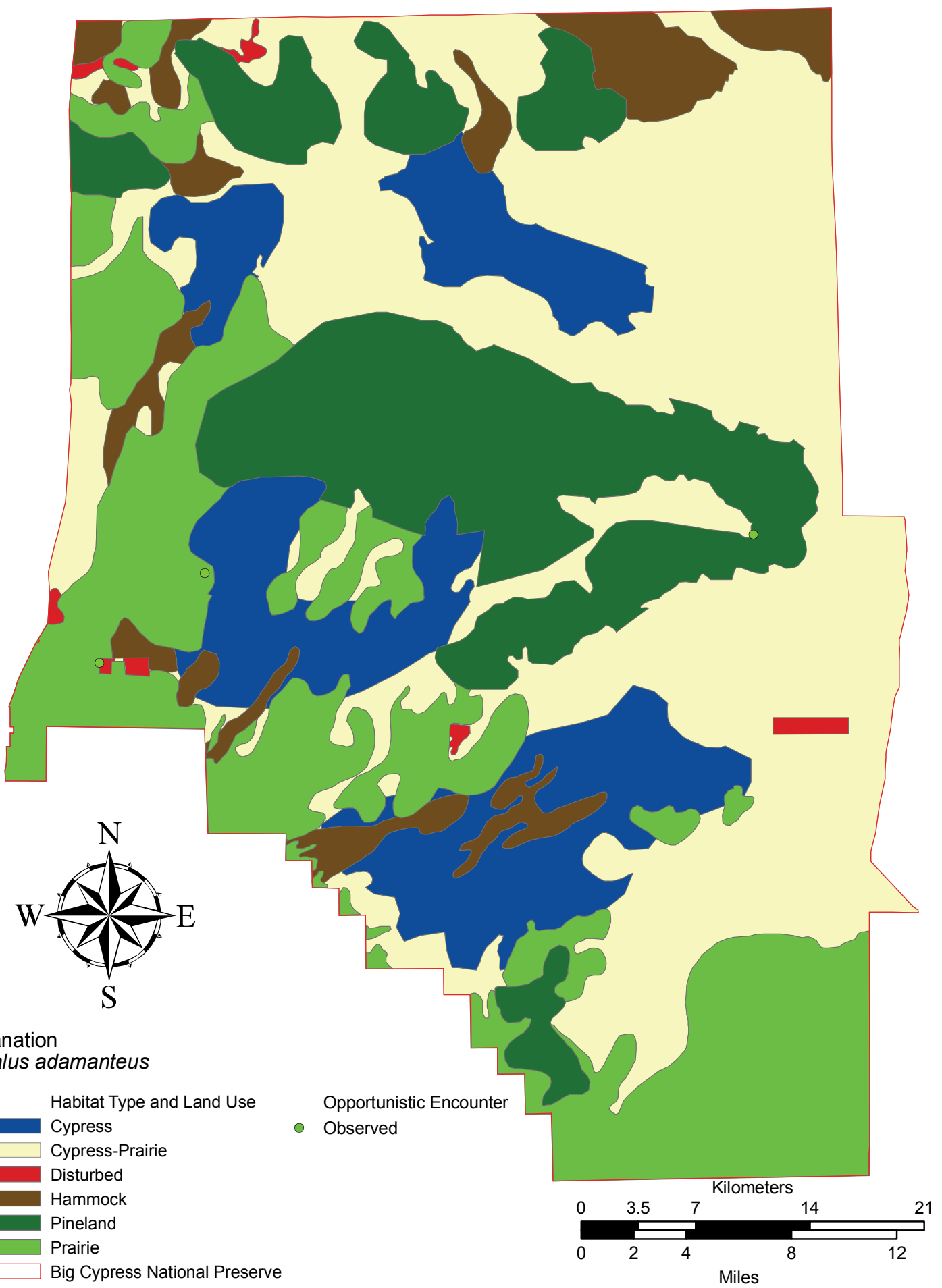

Figure 36. Crotalus adamanteus locations. Map of all locations at which Crotalus adamanteus were observed in Big Cypress National Preserve. 


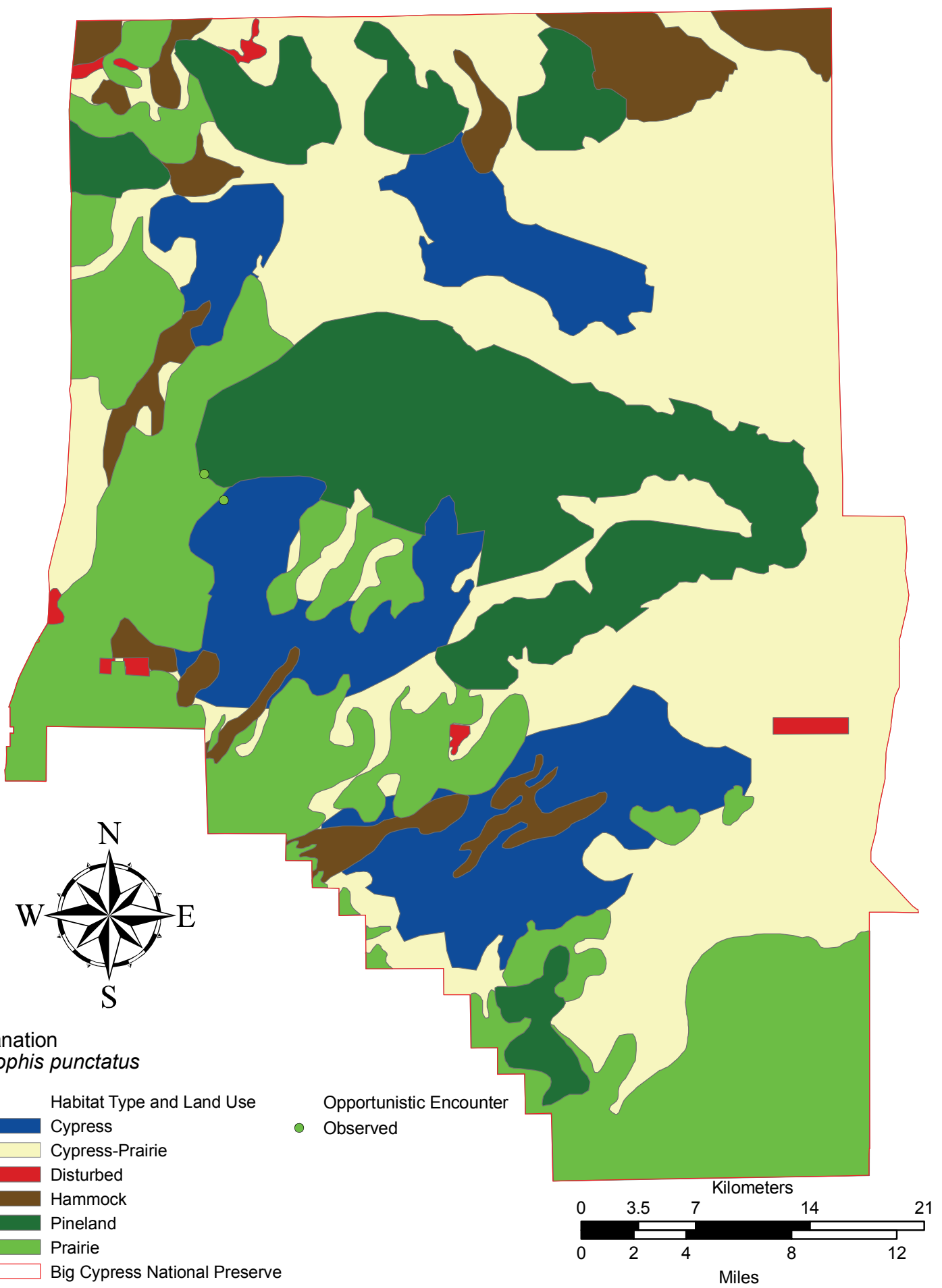

Figure 37. Diadophis punctatus. Map of all locations at which Diadophis punctatus were observed in Big Cypress National Preserve. 


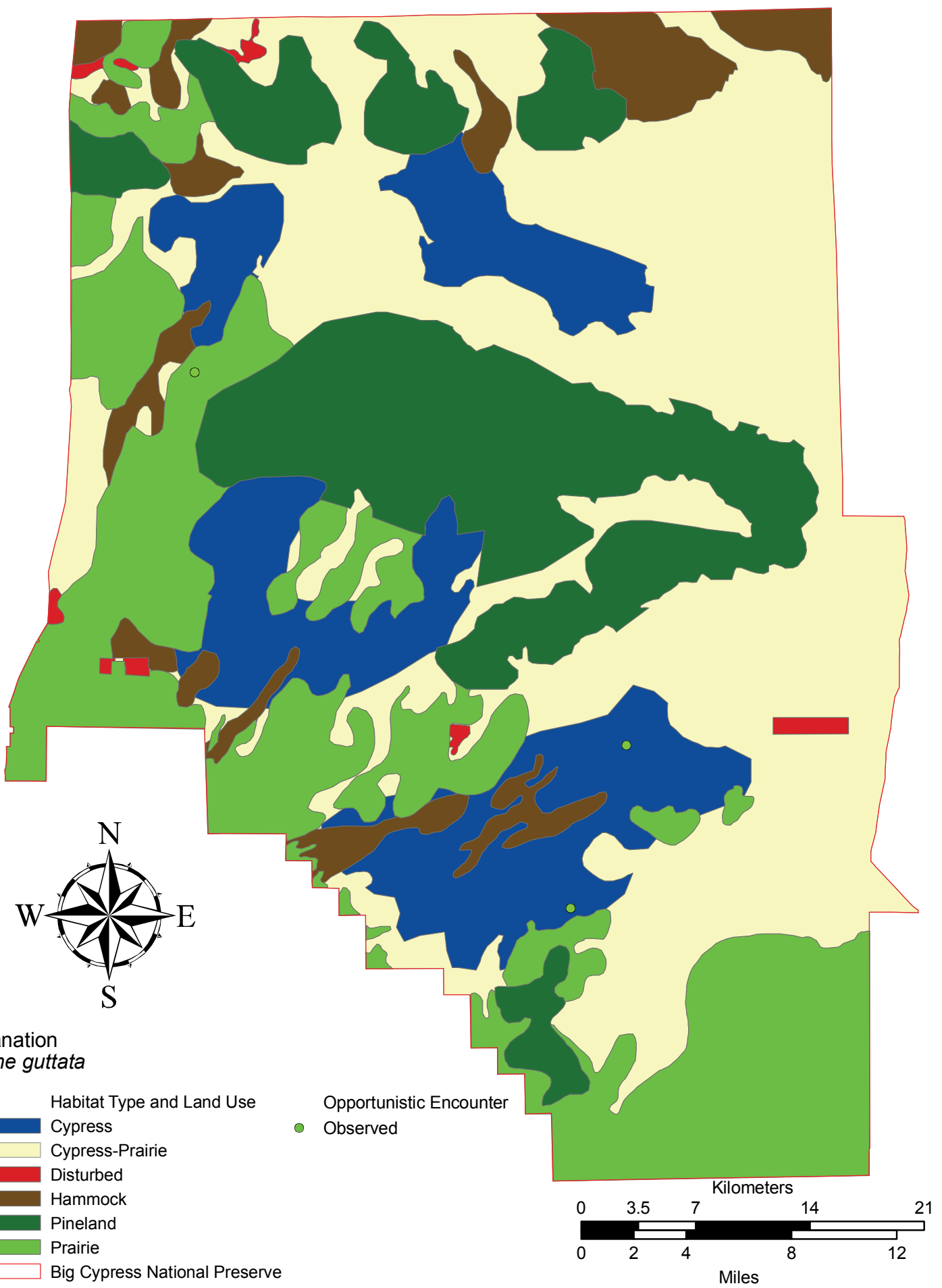

Figure 38. Elaphe guttata locations. Map of all locations at which Elaphe guttata were observed in Big Cypress National Preserve. 


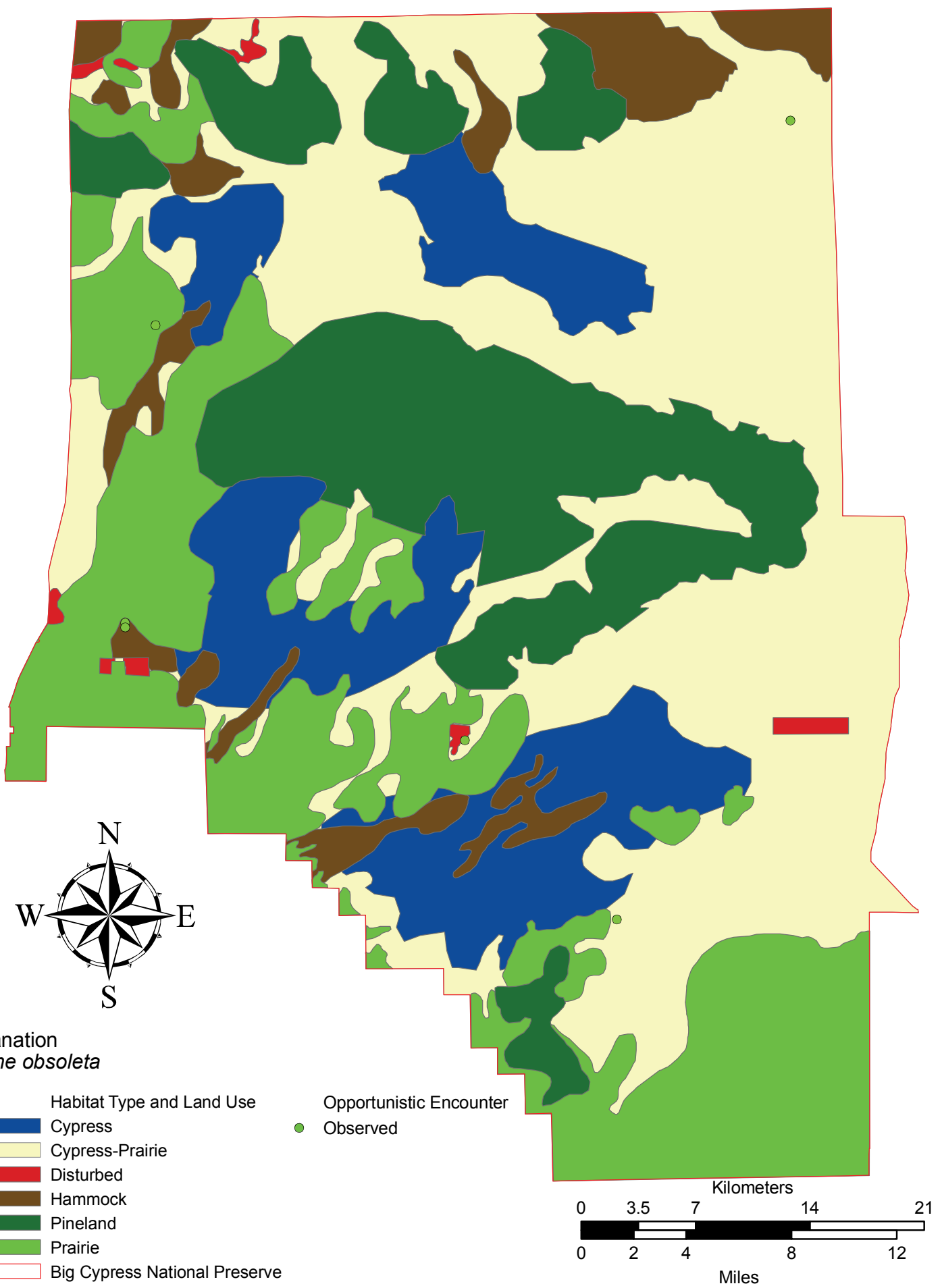

Figure 39. Elaphe obsoleta locations. Map of all locations at which Elaphe obsoleta were observed in Big Cypress National Preserve. 


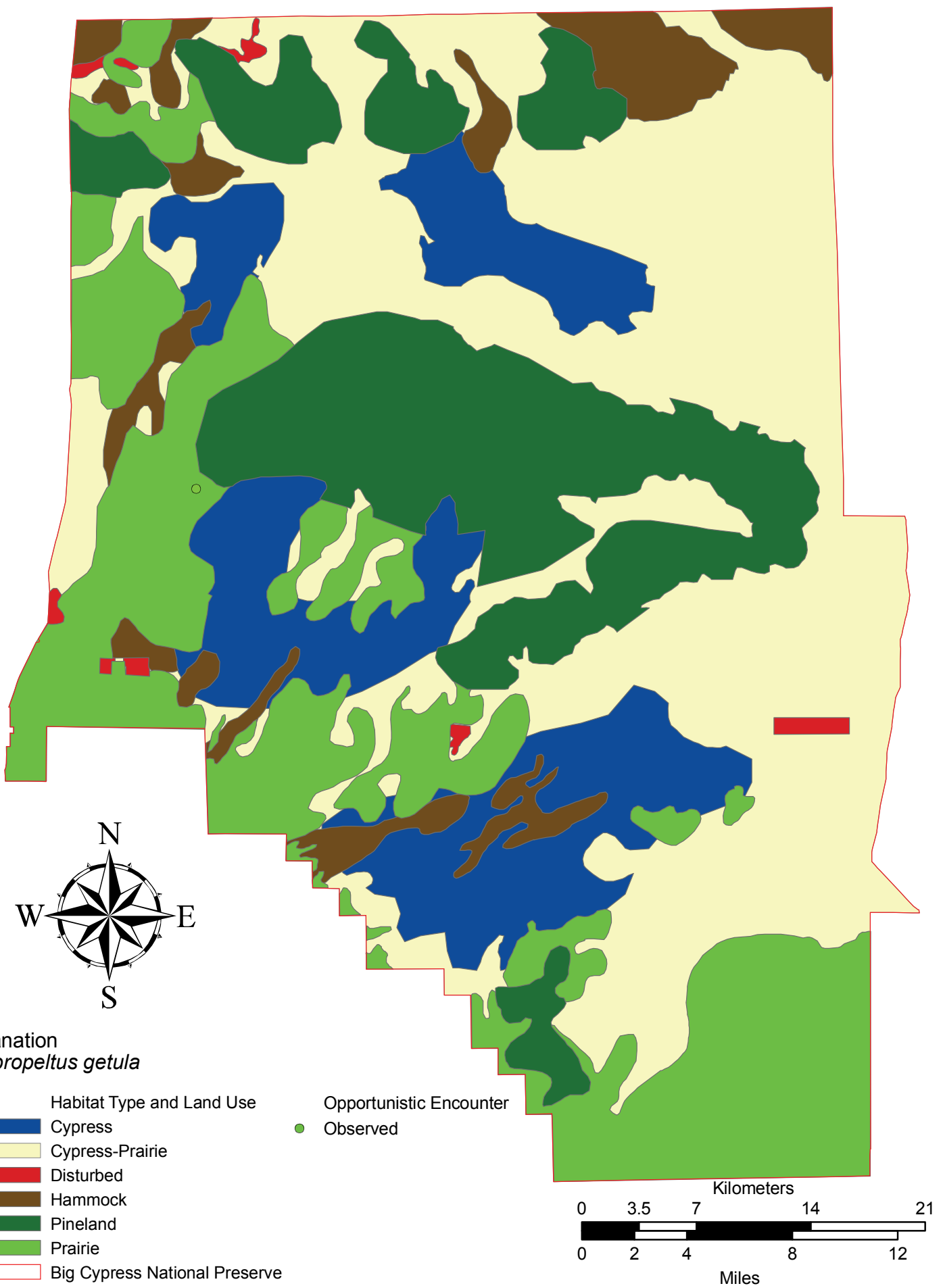

Figure 40. Lampropeltis getula locations. Map of all locations at which Lampropeltis getula were observed in Big Cypress National Preserve. 


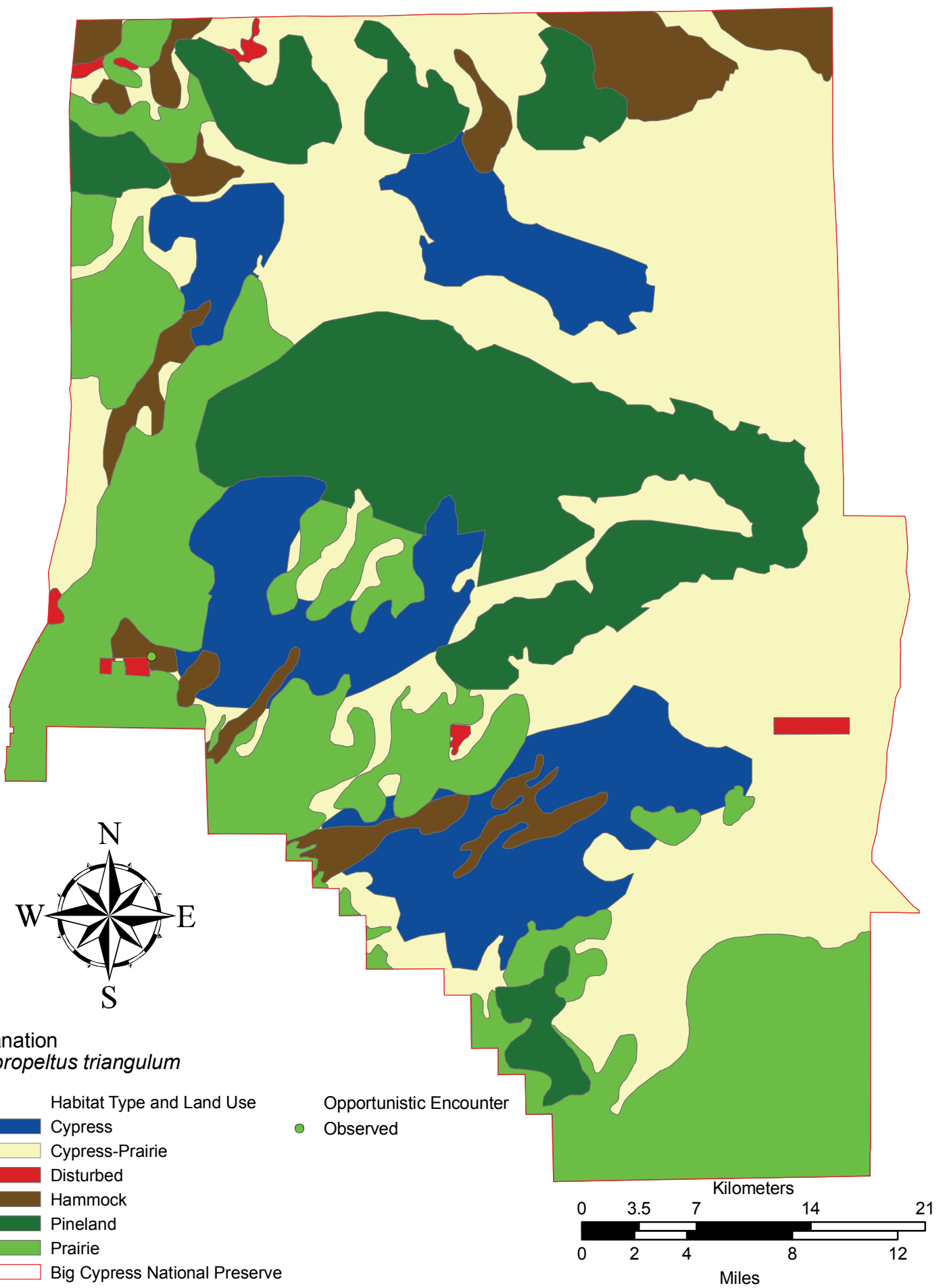

Figure 41. Lampropeltis triangulum locations. Map of all locations at which Lampropeltis triangulum were observed in Big Cypress National Preserve. 


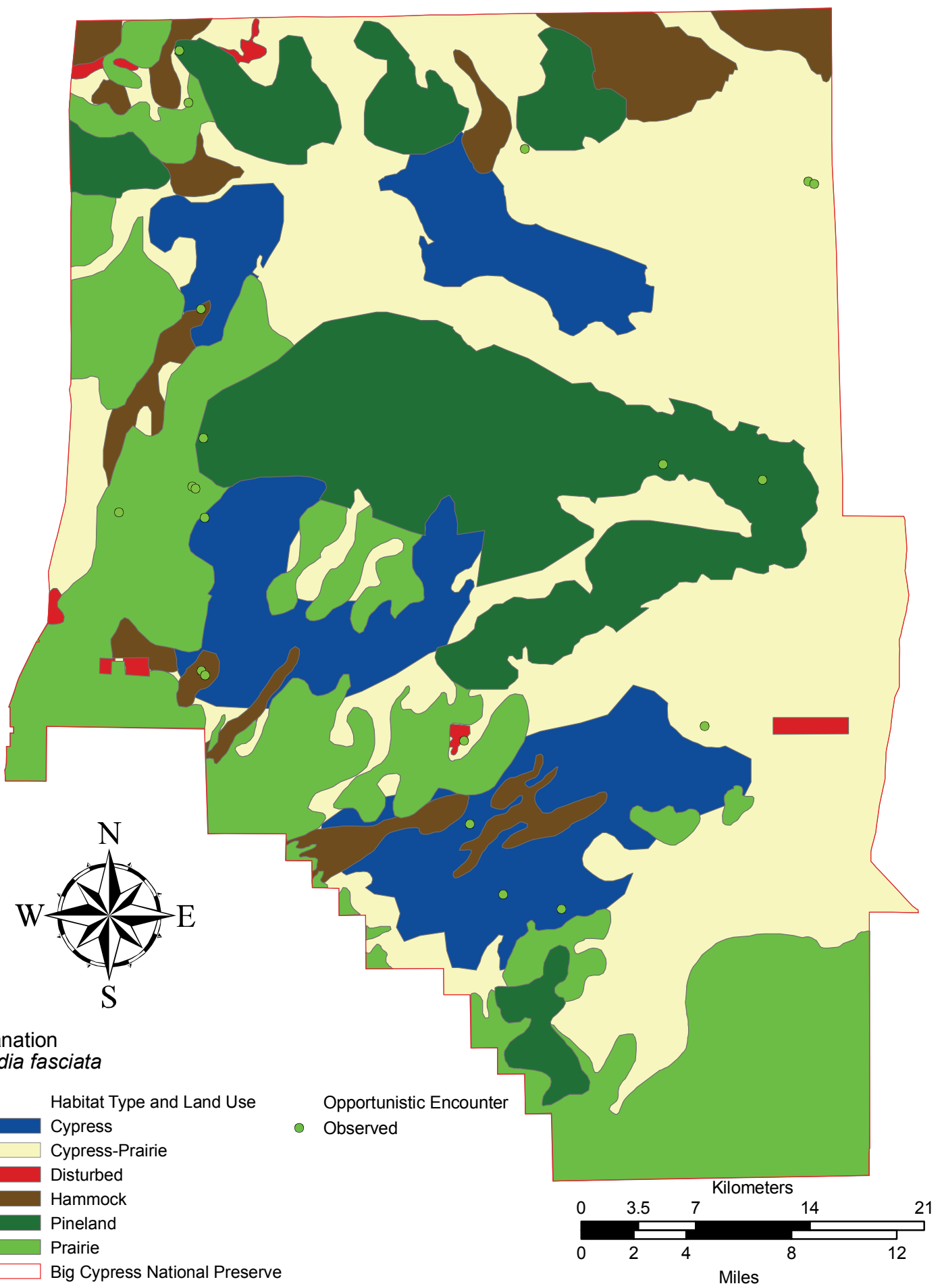

Figure 42. Nerodia fasciata locations. Map of all locations at which Nerodia fasciata were observed in Big Cypress National Preserve. 


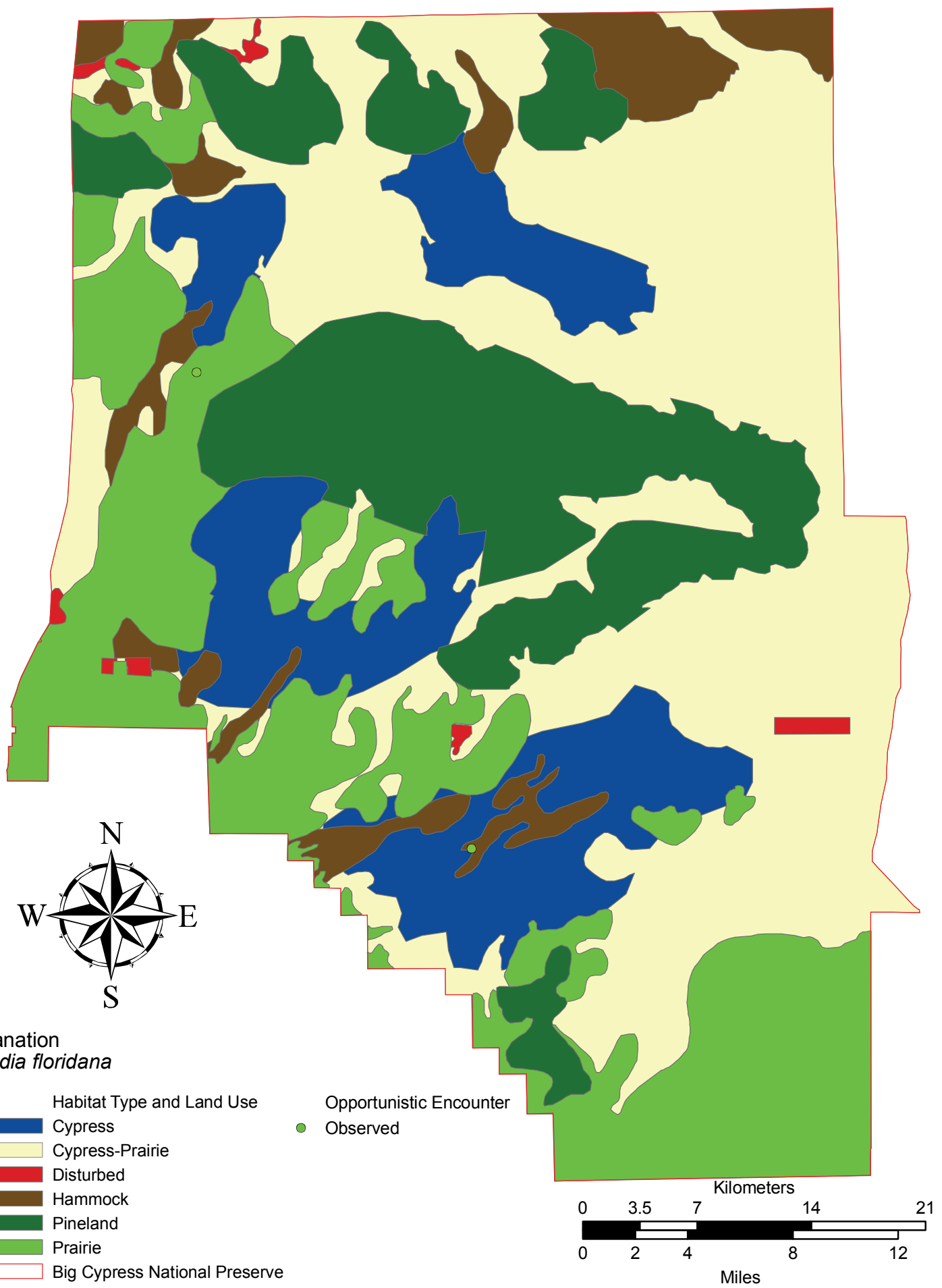

Figure 43. Nerodia floridana locations. Map of all locations at which Nerodia floridana were observed in Big Cypress National Preserve. 


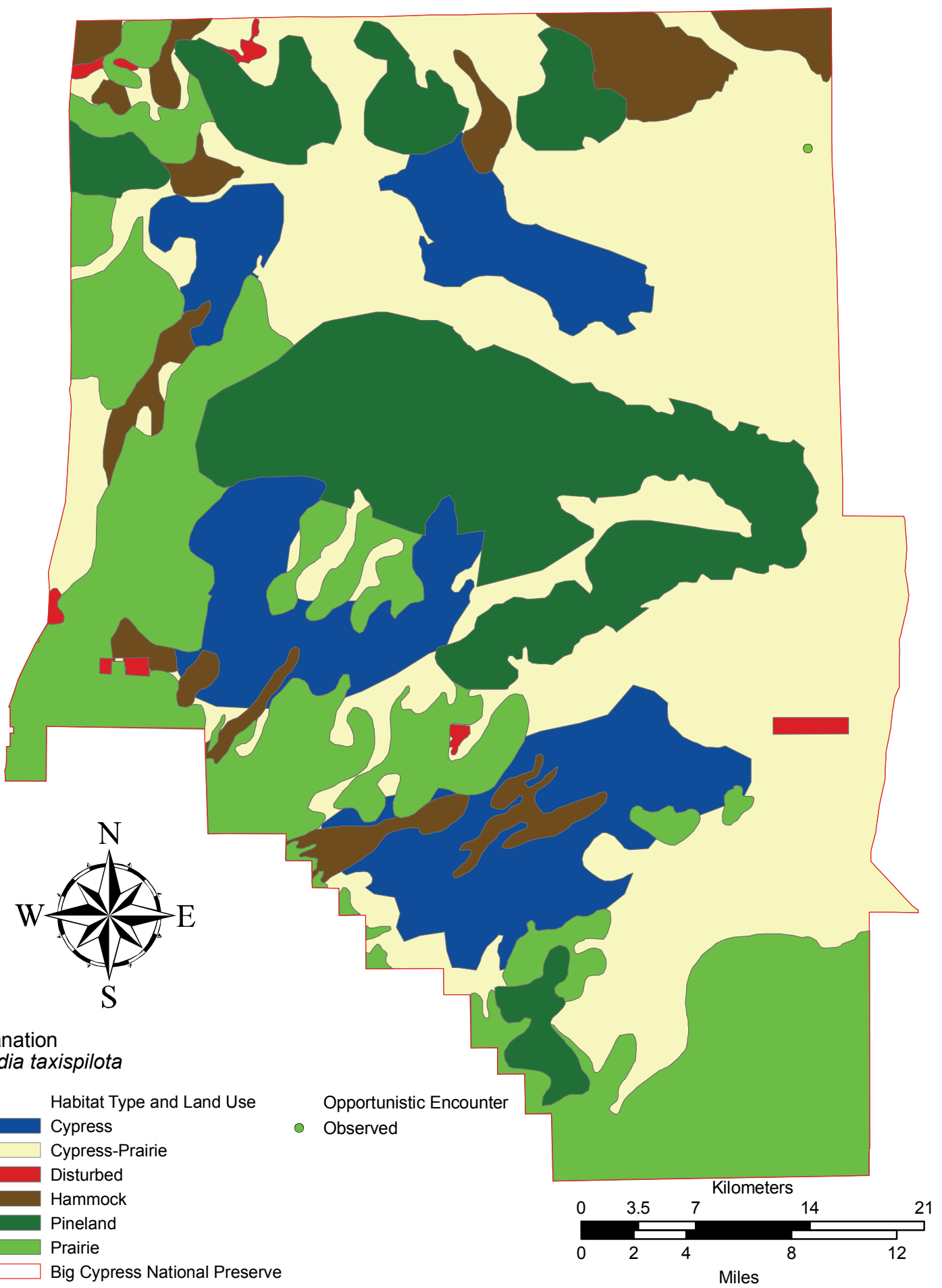

Figure 44. Nerodia taxispilota locations. Map of all locations at which Nerodia taxispilota were observed in Big Cypress National Preserve. 


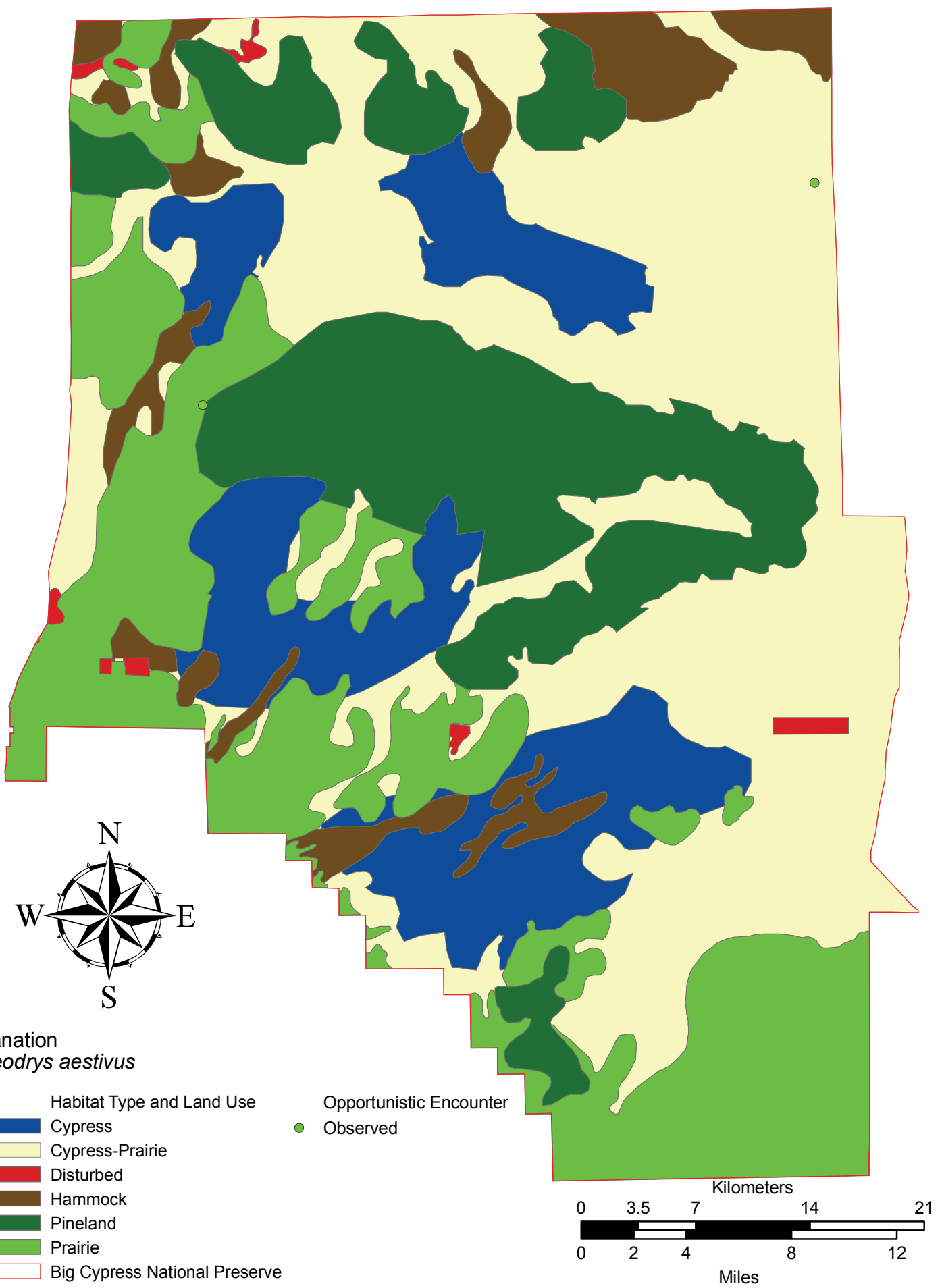

Figure 45. Opheodrys aestivus locations. Map of all locations at which Opheodrys aestivus were observed in Big Cypress National Preserve. 


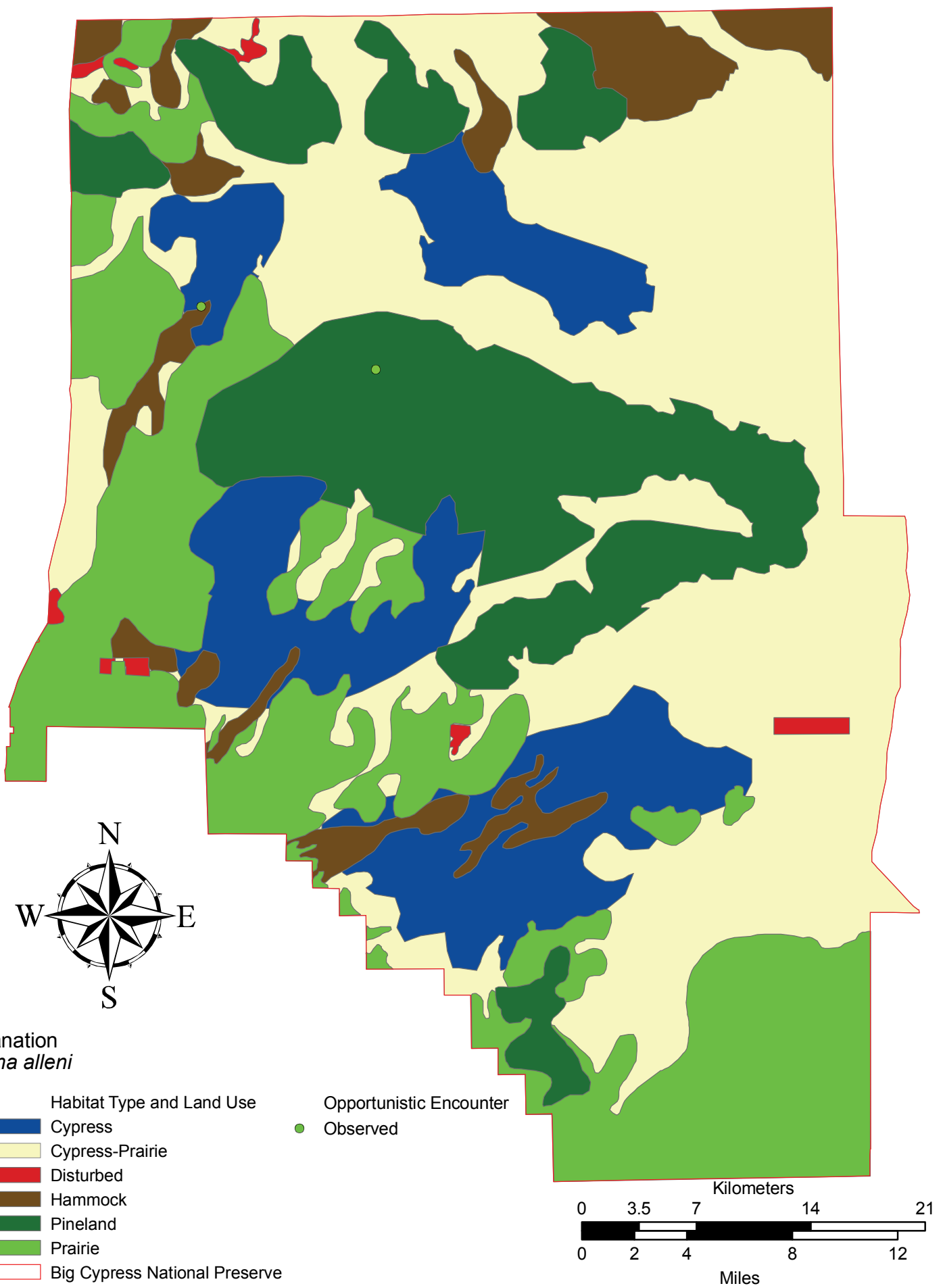

Figure 46. Regina alleni locations. Map of all locations at which Regina alleni were observed in Big Cypress National Preserve. 


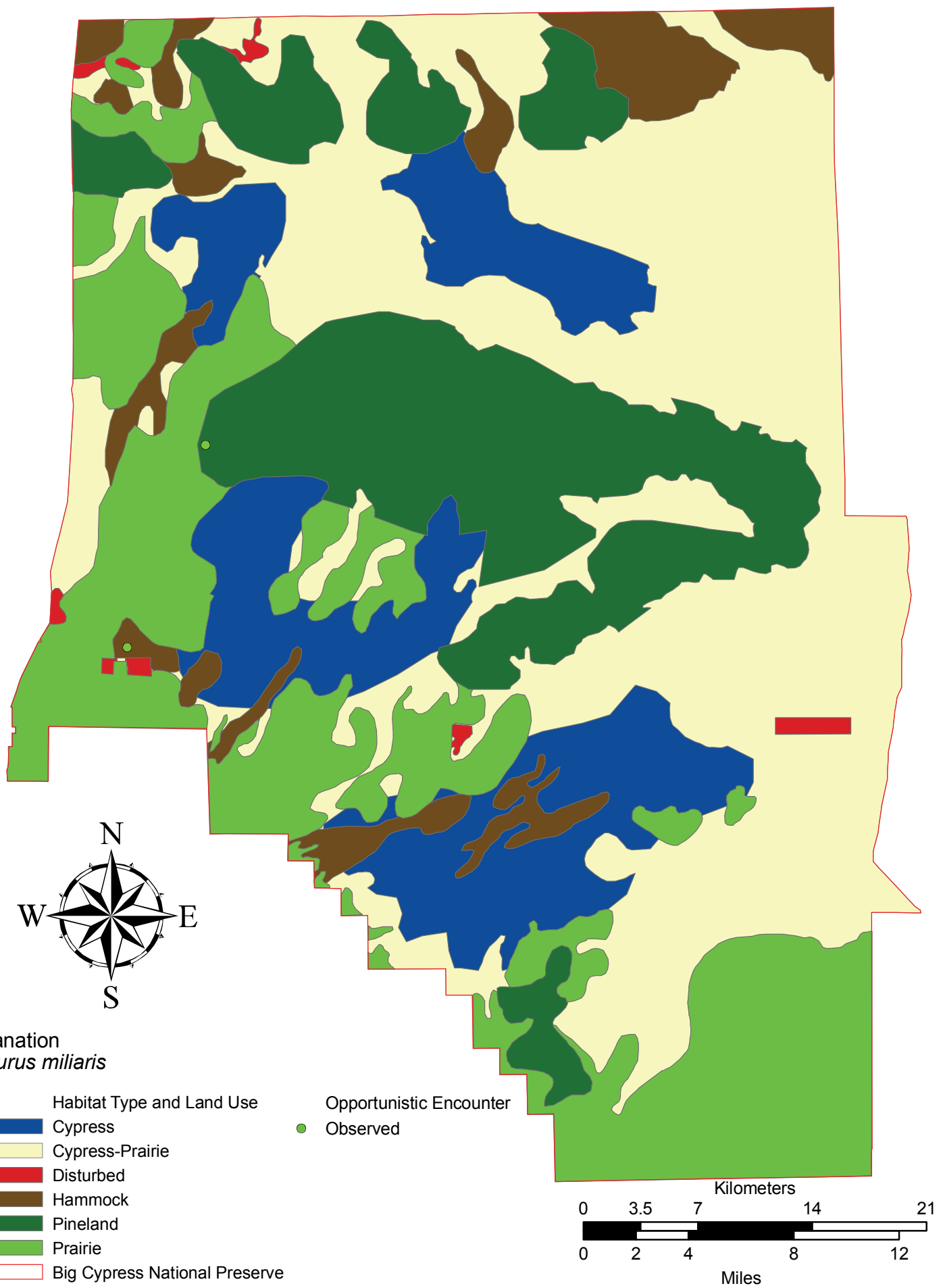

Figure 47. Sistrurus miliarius locations. Map of all locations at which Sistrurus miliarius were observed in Big Cypress National Preserve. 


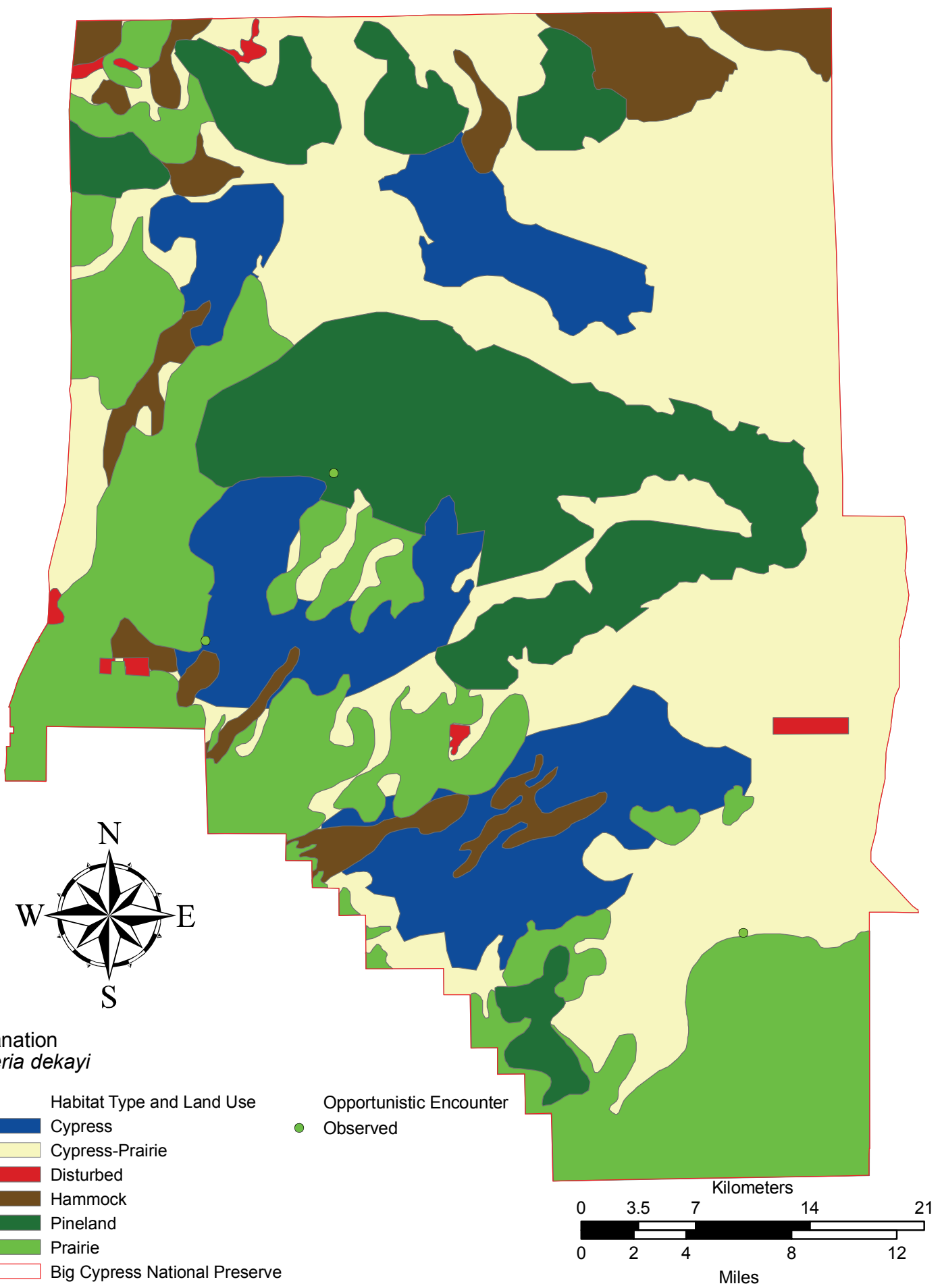

Figure 48. Storeria dekayi locations. Map of all locations at which Storeria dekayi were observed in Everglades National Park. 


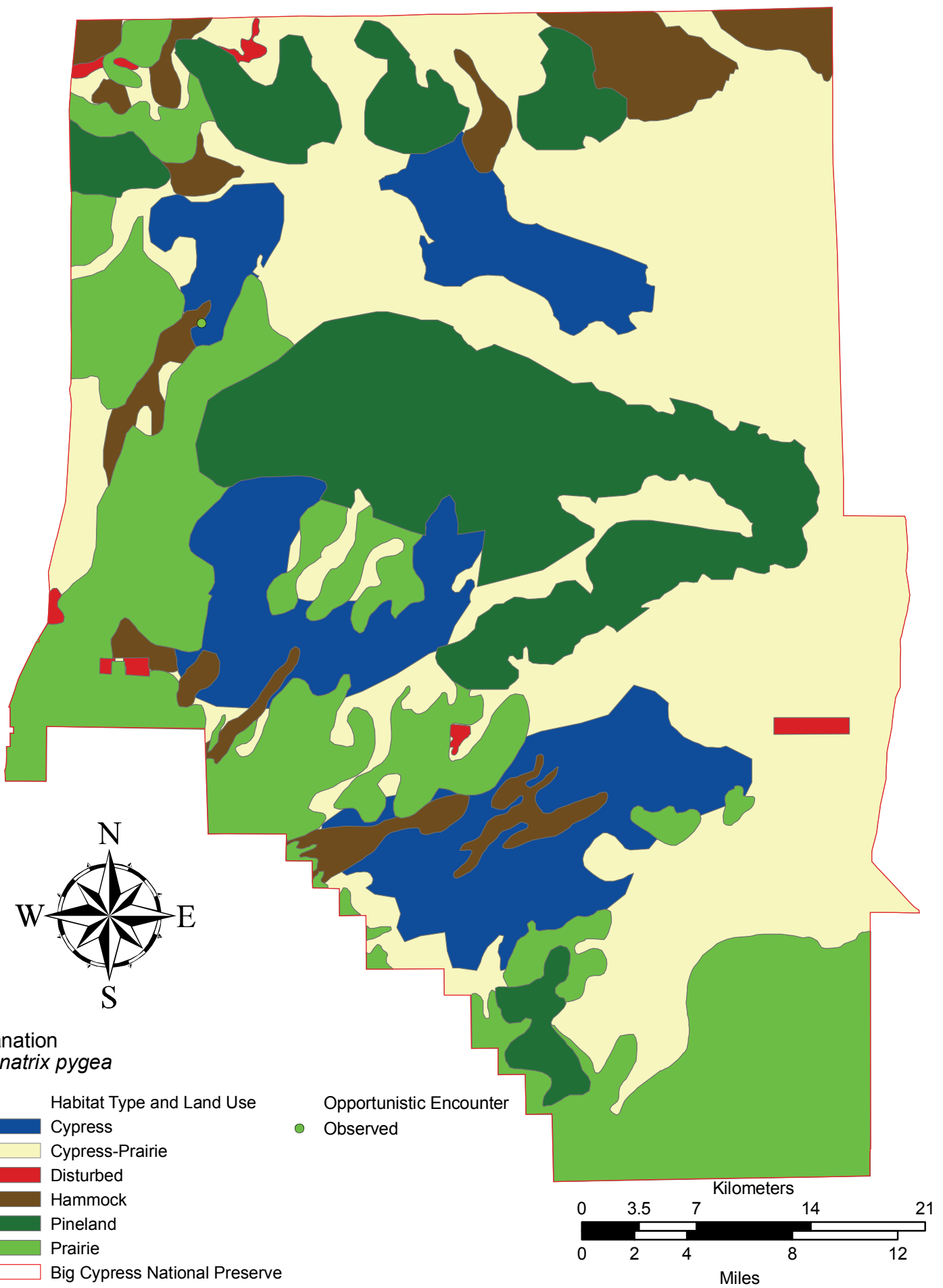

Figure 49. Seminatrix pygea locations. Map of all locations at which Seminatrix pygea were observed in Big Cypress National Preserve. 


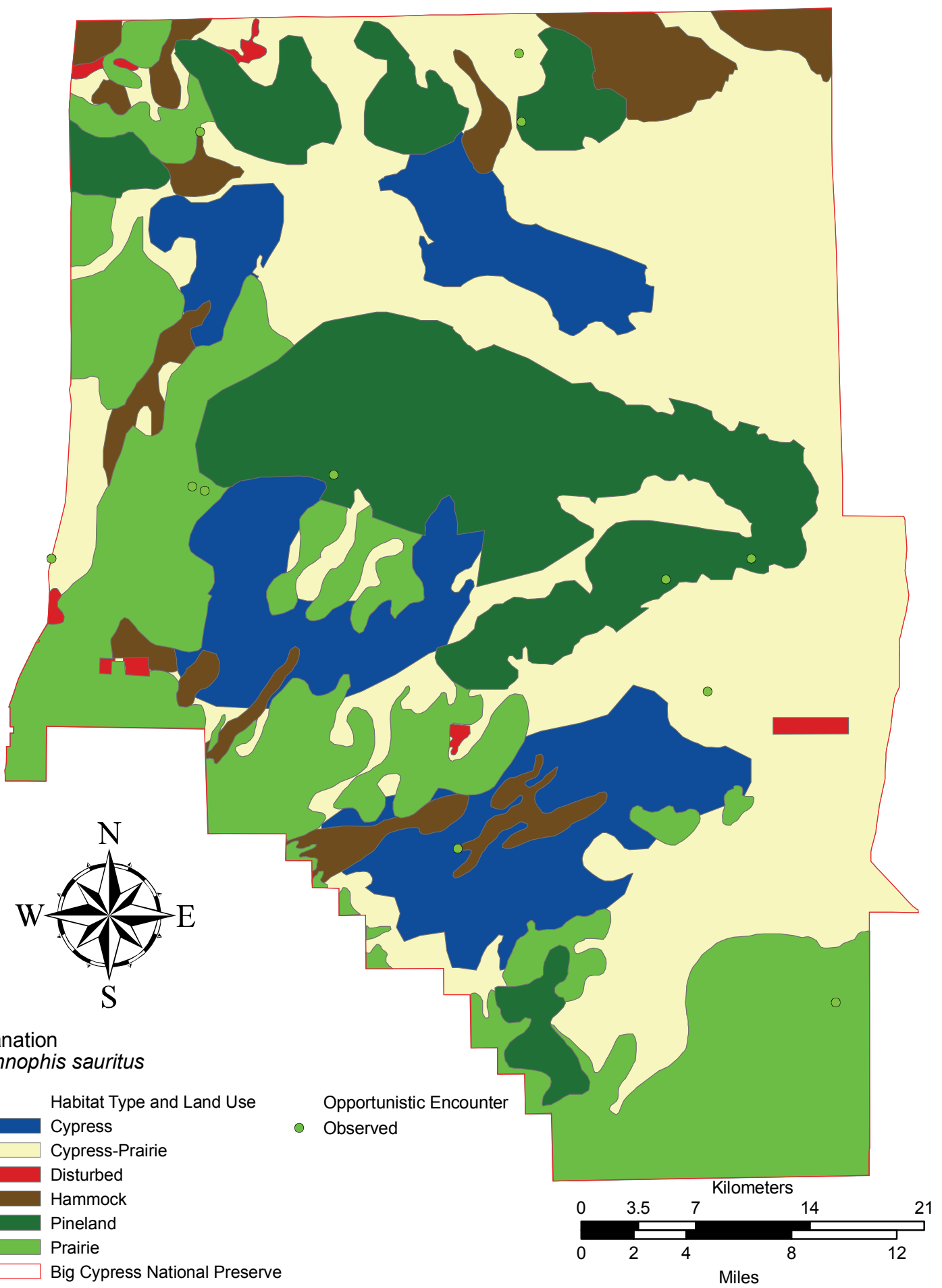

Figure 50. Thamnophis sauritus locations. Map of all locations at which Thamnophis sauritus were observed in Big Cypress National Preserve. 


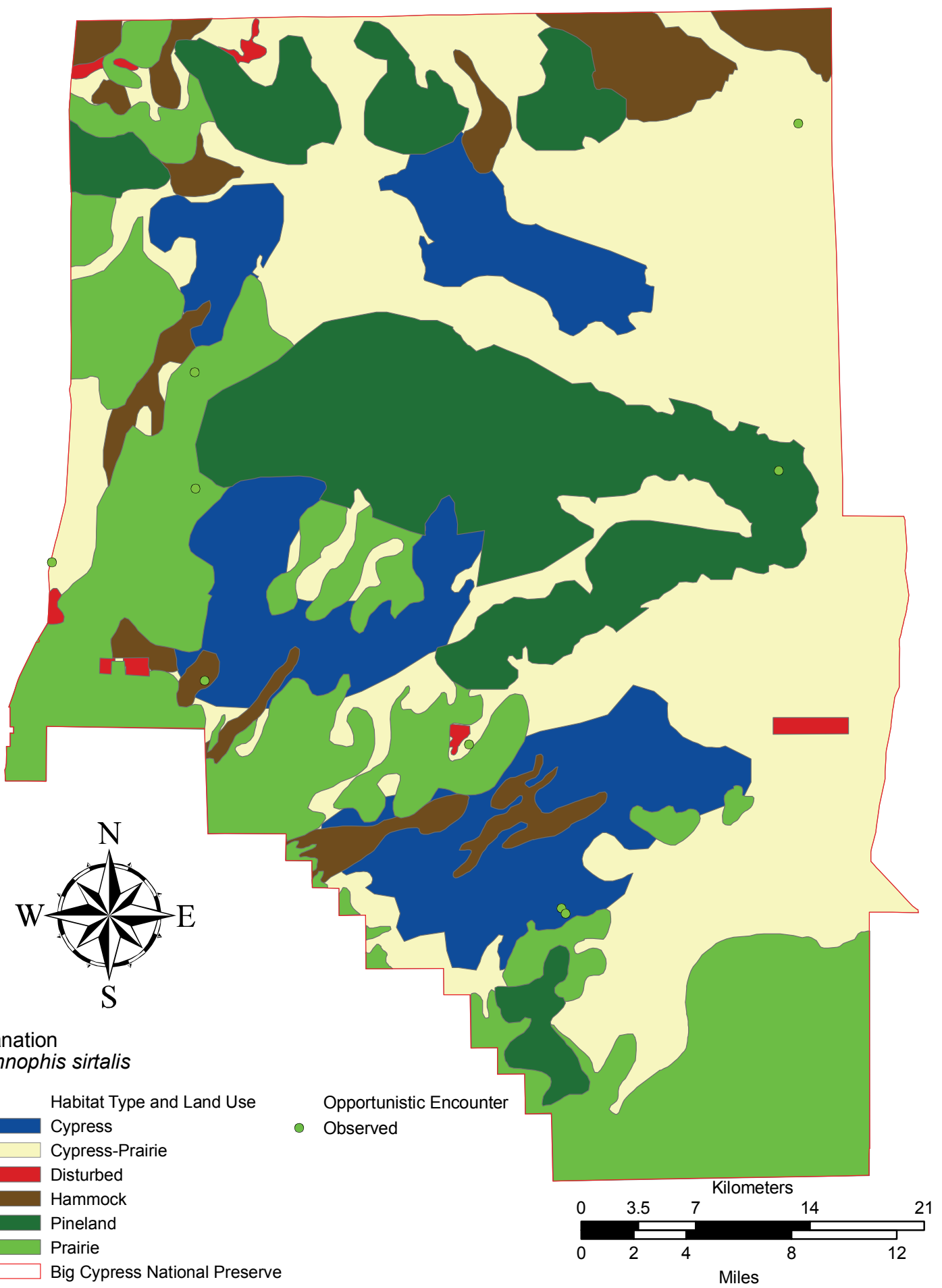

Figure 51. Thamnophis sirtalis locations. Map of all locations at which Thamnophis sirtalis were observed in Big Cypress National Preserve. 


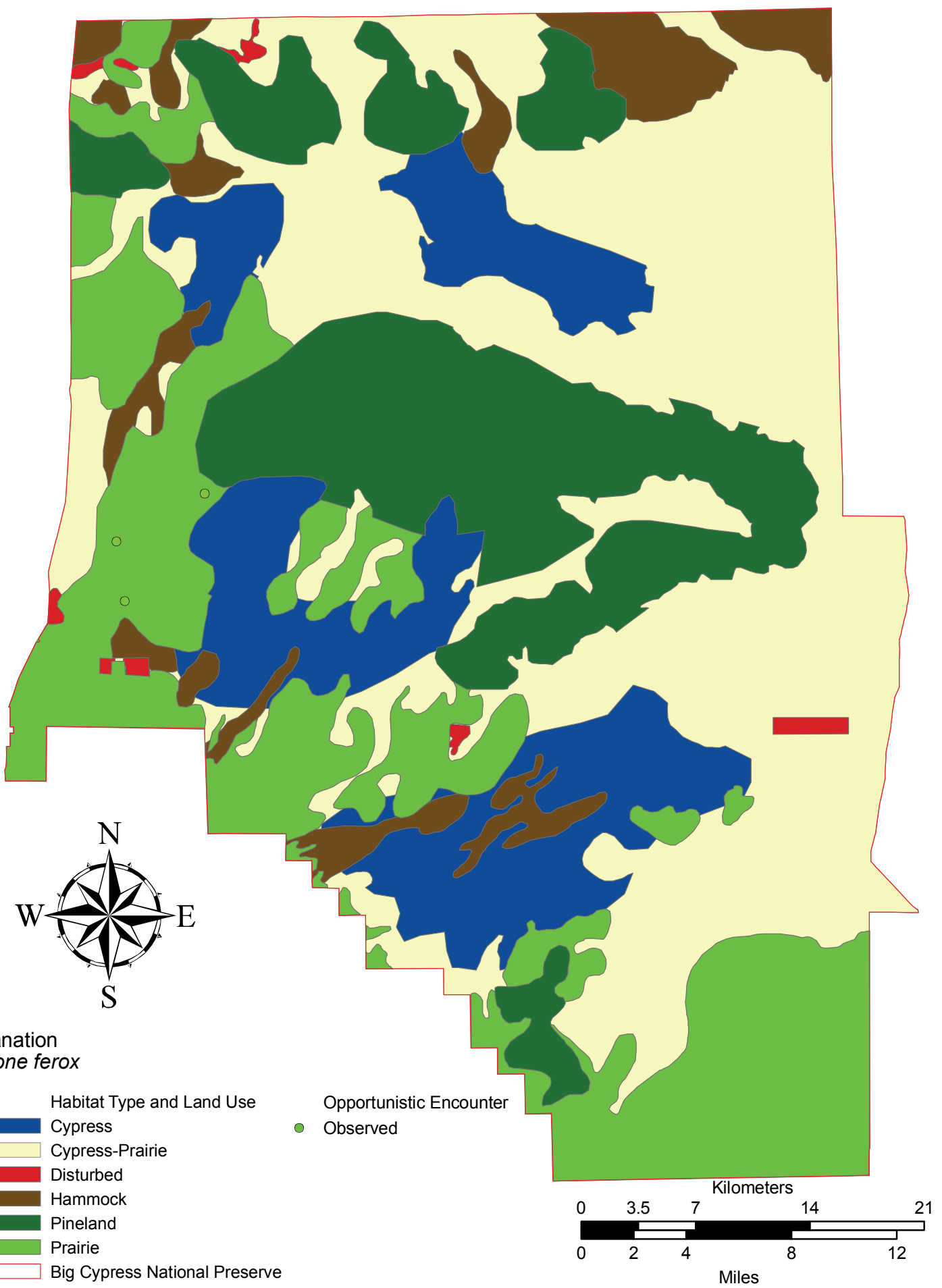

Figure 52. Apolone ferox locations. Map of all locations at which Apolone ferox were observed in Big Cypress National Preserve. 


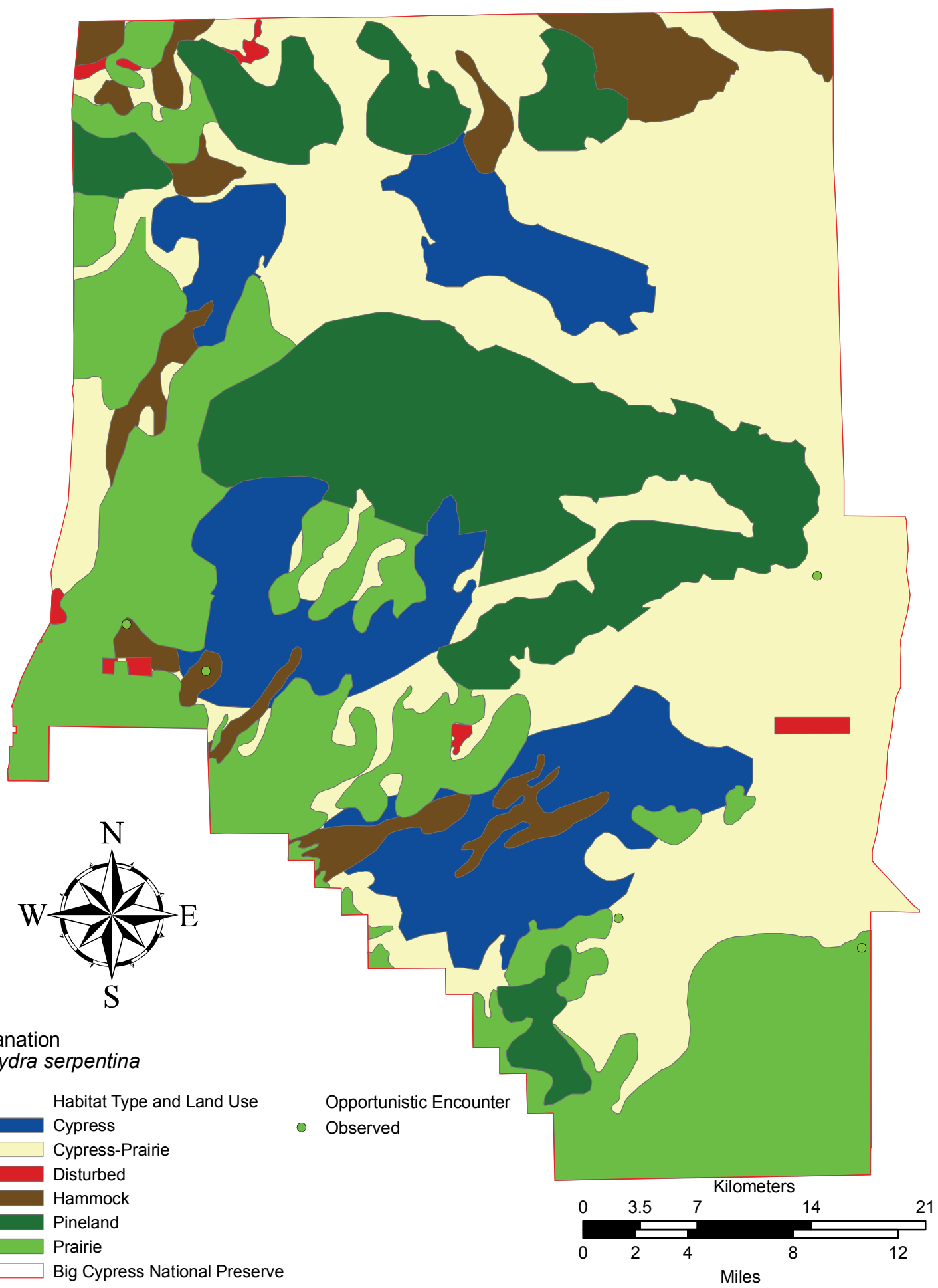

Figure 53. Chelydra serpentina locations. Map of all locations at which Chelydra serpentina were observed in Big Cypress National Preserve. 


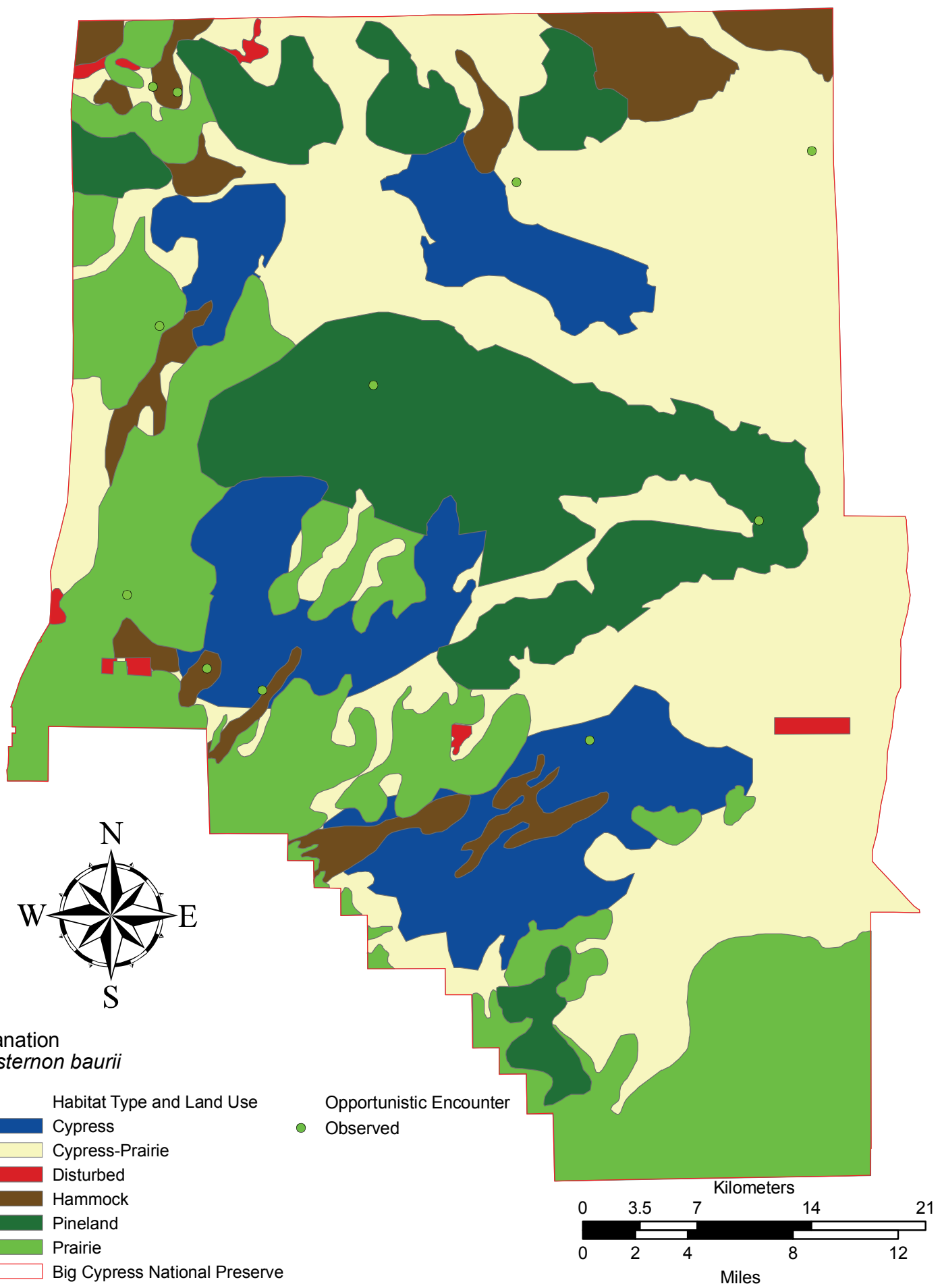

Figure 54. Kinosternon baurii locations. Map of all locations at which Kinosternon baurii were observed in Big Cypress National Preserve. 


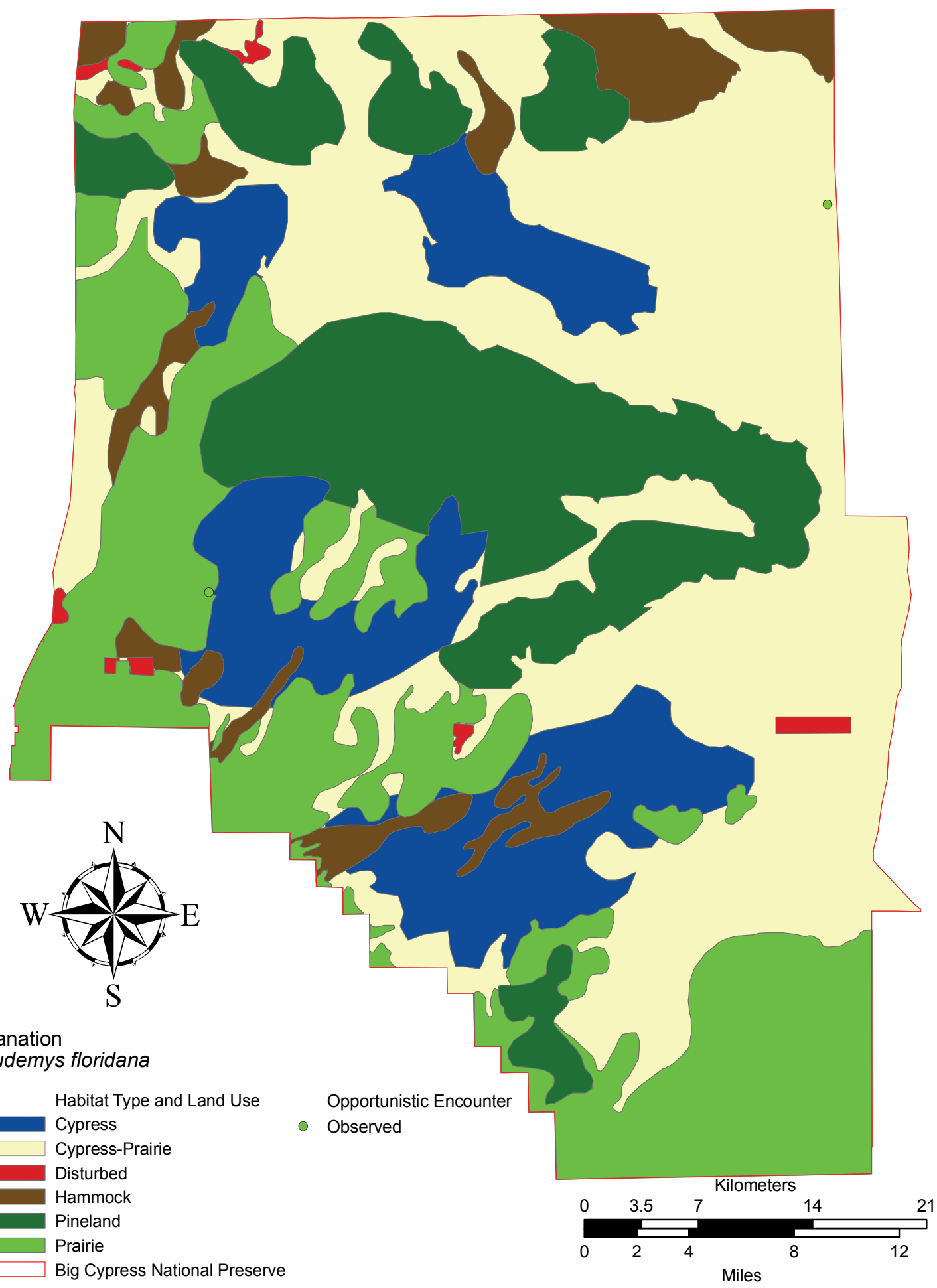

Figure 55. Pseudemys floridana locations. Map of all locations at which Pseudemys floridana were observed in Big Cypress National Preserve. 


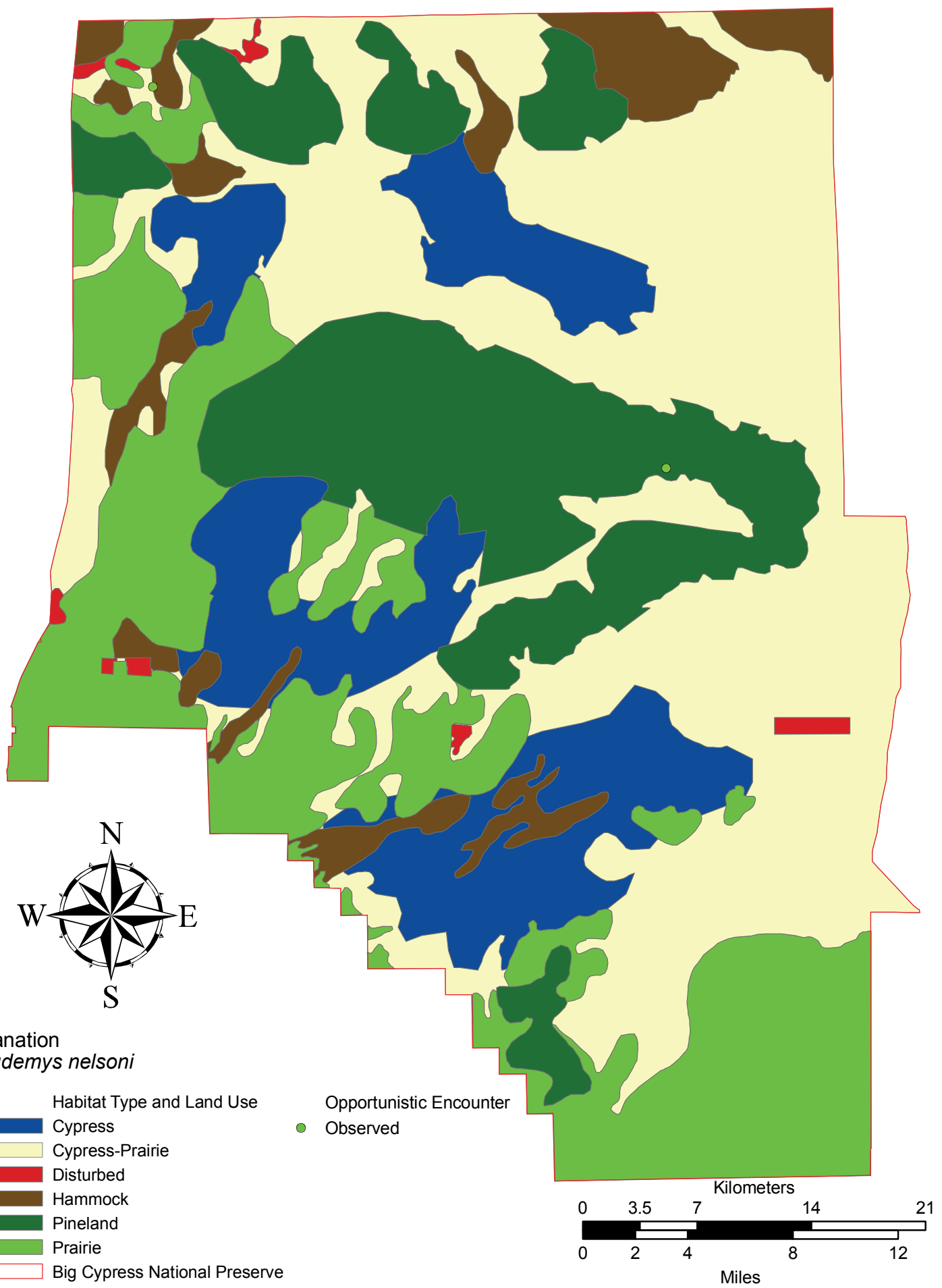

Figure 56. Pseudemys nelsoni locations. Map of all locations at which Pseudemys nelsoni were observed in Big Cypress National Preserve. 


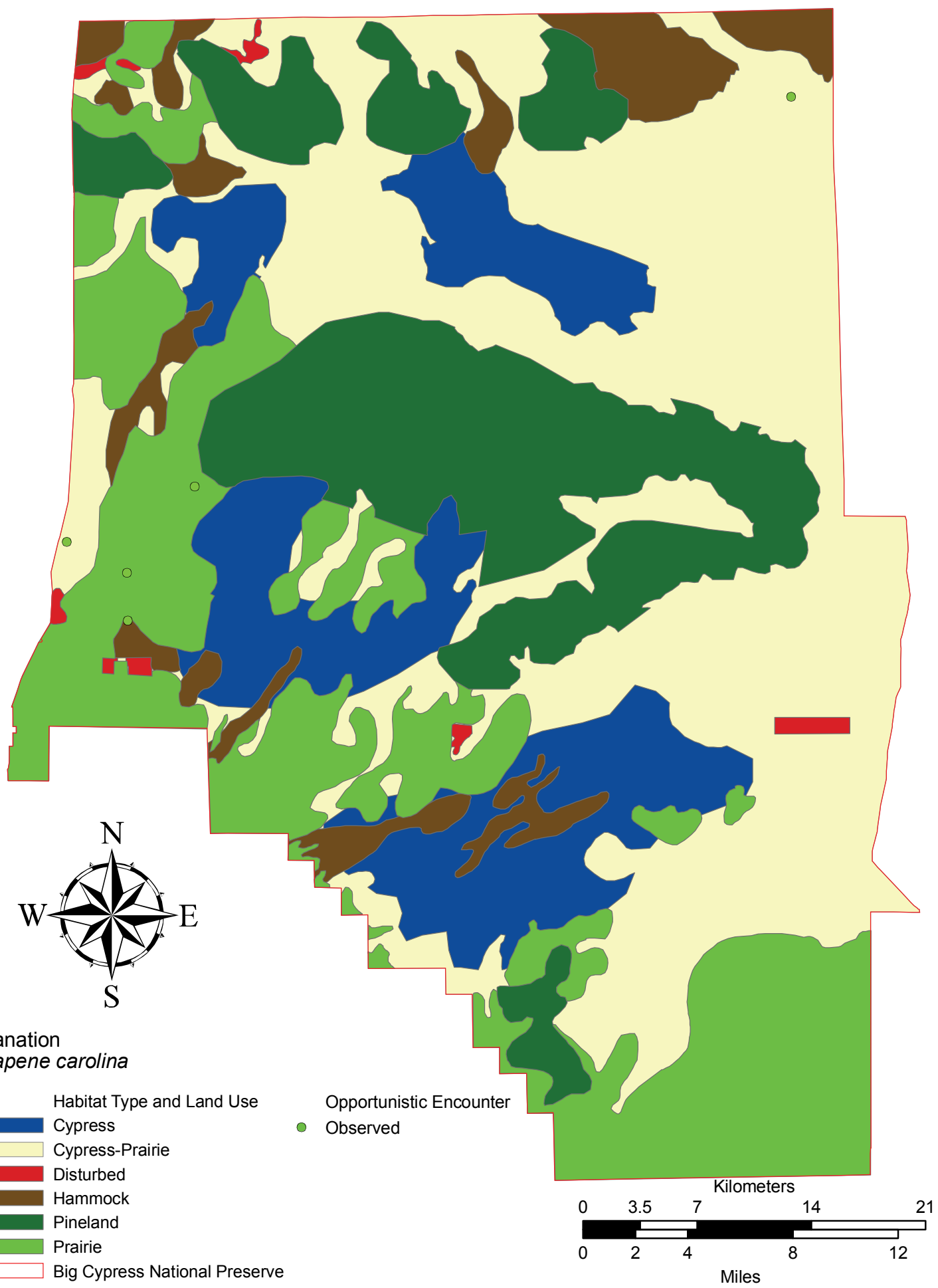

Figure 57. Terrapene carolina locations. Map of all locations at which Terrapene carolina were observed in Big Cypress National Preserve. 